\title{
EFEITO DO BTH NA EXPRESSÃO DE ISOENZIMAS E NA INTERAÇÃO DE MICROSSIMBIONTES E NEMATÓIDES FITOPATOGÊNICOS COM PLANTAS DE SOJA
}

\author{
LÚCIA VIEIRA HOFFMANN
}

Engenheiro Agrônomo

Orientadora: Profa. Dra. ELKE J. BRAN NOGUEIRA CARDOSO

Tese apresentada à Escola Superior de Agricultura "Luiz de Queiroz", Universidade de São Paulo, para obtenção do título de Doutor em Agronomia, Área de Concentração: Microbiologia Agrícola.

PIRACICABA

Estado de São Paulo - Brasil

Setembro - 2000. 


\section{ERRATA}

HOFFMANN, L. V. Efeito do BTH na expressão de isoenzimas e na interação de microssimbiontes e nematóides fitopatogênicos com plantas de soja.

\section{Capítulo 5 - Resultados:}

Na página 61, Tabela 5, para BTH via folha, 18 e 19 dap e $G$. intraradices, leia-se 6,73.

Na página 79 , segundo parágrafo, leia-se: Não houve diferença significativa entre médias de absorbância dos extratos dos cotilédones tratados com água ou BTH, segundo o teste $F(p<0,05)$. Cotilédones tratados com $S$. cerevisae apresentaram valores de absorbância maiores que os dos outros tratamentos, segundo o mesmo teste estatístico.Tabela 26, para Saccharomyces cerevisae, leia-se 0,725b.

Nos títulos das Tabelas 27 e 28, página 81, e Tabela 29, página 82, onde está "Efeito de BTH no extrato de compostos fenólicos", leia-se "Medidas médias de absorbância a $285 \mathrm{~nm}$ em extratos".

Na página 83 , Tabela 30 , para tratamento controle, sem inoculação, leia-se 0,864 . No título da Tabela 30 e no da Tabela 31 da página 84 , onde está escrito fitoalexinas, leia-se compostos fenólicos.

Na página 91, Figura 16, onde está L, leia-se $F$.

\section{Outros capítulos:}

\begin{tabular}{|c|c|c|c|}
\hline item & linha & onde se lê & leia-se \\
\hline Summary & 10 & this & these \\
\hline Summary & 10 & polyacrylamide native gels & native polyacrylamide gels \\
\hline 3.2 & 18 e 22 & Bonfarte-Fasolo & Bonfante-Fasolo \\
\hline 4.1 & 6 & molar & molecular \\
\hline $4.2 d)$ & 8 & $1,1 \mathrm{~S}(454 \mathrm{~g} / \mathrm{L})$ & $1,15 S$ \\
\hline 4.3 & 19 & $18^{\circ}$ & $14^{\circ}$ \\
\hline 4.6 & 3 & 1933 & 1993 \\
\hline 4.6 & 5 & galhas & fêmeas \\
\hline 4.6 & 7 & fêmeas & galhas \\
\hline $4.11 d)$ & 11 & quitina & quitina-glicol \\
\hline Referências & 13 & BONFARTE-FASOLO & BONFANTE-FASOLO \\
\hline Referências & 6 & GIANINNAZZI-PEARSON & GIANINAZZI-PEARSON \\
\hline Referências & 6 & GIANINNAZZI & GIANINAZZI \\
\hline Referências & 3 & GIANINNAZZI-PEARSON & GIANINAZZI-PEARSON \\
\hline Referências & 5 & GIANINNAZZI-PEARSON & GIANINAZZI-PEARSON \\
\hline Referências & 17 & GIANINNAZZI & GIANINAZZI \\
\hline Referências & 9 & 1933 & 1993 \\
\hline Referências & 18 & p. 282 & p. 257-82 \\
\hline Referências & 17 & v. 175 & v. 178 \\
\hline
\end{tabular}




\section{Dados Internacionais de Catalogação na Publicação (CIP) DIVISÃO DE BIBLIOTECA E DOCUMENTAÇĀO - Campus "Luiz de Queiroz"/USP}

Hoffmann, Lúcia Vieira.

Efeito do BTH expressão de isoenzimas e na interação de microssimbiontes e nematóides fitopatogênicos com plantas de soja / Lúcia Vieira Hoffmann. - - Piracicaba, 2000.

$136 \mathrm{p}$.

Tese (doutorado) - Escola Superior de Agricultura Luiz de Queiroz, 2000.

Bibliografia.

1. Fungo micorrízico 2. Nematóide parasito de planta 3. Rizóbio 4. Soja I. Título

CDD 633.34

"Permitida a copia total ou parcial deste documento, desde que citada a fonte - 0 autor" 


\section{A Sônia, minha mãe. Demorei tanto para saber o quanto aprendi com você, e ainda não sei.}

A Guto e Guilherme, com amor. 


\section{AGRADECIMENTOS}

A CAPES e aos coordenadores do Curso de Pós-Graduação em Microbiologia Agrícola pela bolsa concedida.

A Prof ${ }^{a}$ Dr. ${ }^{a}$ Elke J. B. Nogueira Cardoso, minha orientadora neste trabalho, pela sugestão de tema e auxílio na sua condução e redação.

A Dra. Maria Teresa V. Carvalho pela cessão de uso do Laboratório de Melhoramento Vegetal, do CENA/USP, de drogas para confecção de géis e pela discussão dos resultados que dizem respeito a géis de isoenzimas.

Ao M. Sc. Guilherme Lafourcade Asmus pela cessão de ovos e larvas e instruções sobre os procedimentos com dos nematóides utilizados neste estudo.

Ao Prof. Dr. Ricardo de Azevedo, do Depto. de Genética da ESALQ/USP, pela leitura e sugestões de um artigo escrito sobre a parte deste trabalho que diz respeito a géis de isoenzimas.

Ao Prof. Dr. Luiz Carlos Ferraz, do Depto de Entomologia, Fitopatologia e Zoologia Agrícola, pelas correções de um artigo sobre a parte de nematóides contida neste trabalho.

A Dra. Vera Maria Quecini pela leitura da tese e sugestões.

A Denise de Lourdes Colombo Mescholoti, Luis Fernando Baldesin e Raquel Myriam Orsi pelas dicas na coloração de fungos micorrízicos, de elaboração de géis e ajuda nas colheitas dos experimentos em casa de vegetação. 
A M. Sc. Luciana Rossini Pinto pelas dicas com as cubas para eletroforese.

Aos colegas Ângela, Beatriz, Beth, Cleide, Heron, Leandra, Marco, Marcelo, Maria Izabel, Milene, Paulo, Renata, Robinson, Taís e Winston, pela oportunidade de dividir problemas e resolve-los juntos.

À minha família, especialmente Antônia e Geraldo, meus pais tortos, pelo amor e dedicação ao nosso menino e nossa avó. 


\section{SUMÁRIO}

Página

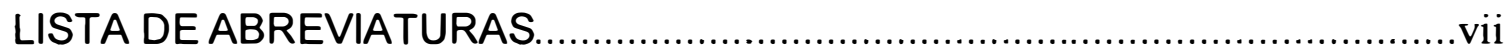

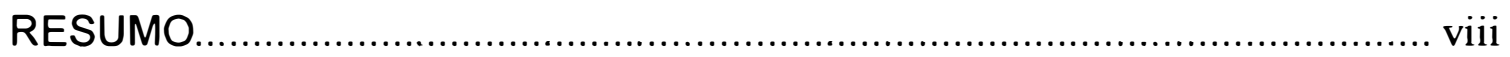

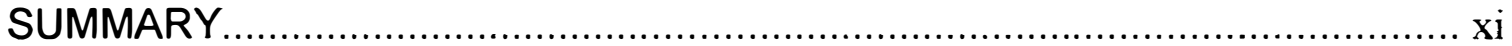

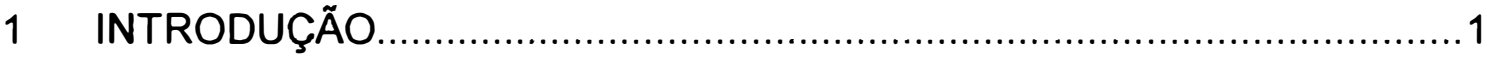

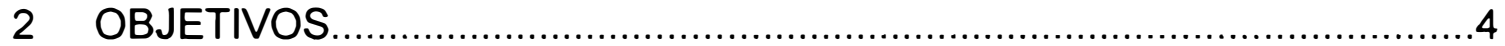

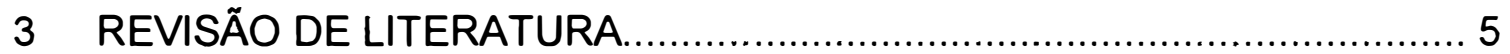

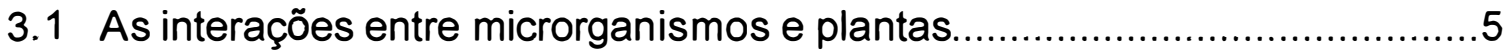

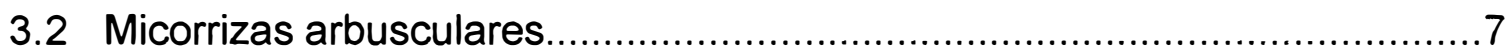

3.3 Rizóbio e a interação simbiótica com leguminosas..................................11

3.4 Nematóides fitopatogênicos e a interação com plantas............................13

3.5 Interfaces entre relações simbióticas e patogênicas entre plantas e

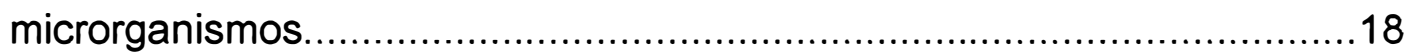

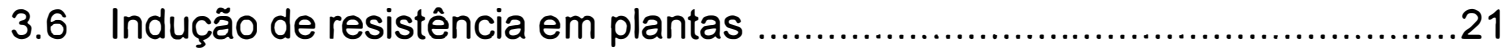

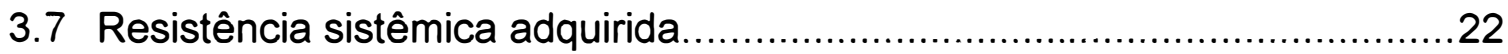

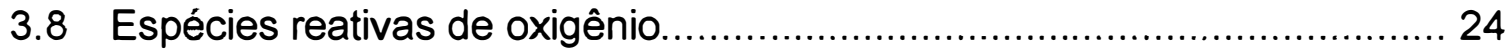

3.9 Marcadores bioquímicos nas interações entre plantas

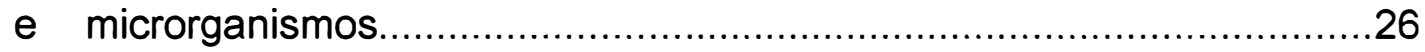

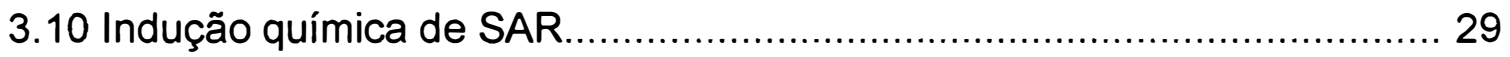

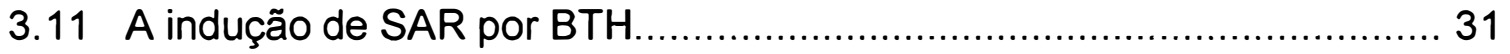

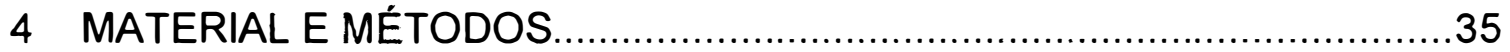

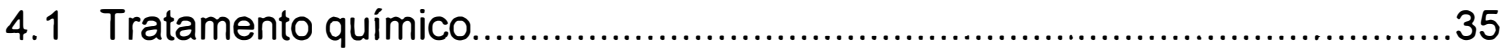

4.2 Manutenção dos microssibiontes e nematóides e preparo de inóculo. 
Página

4.3 Ensaios envolvendo aplicação radicular e foliar de BTH em plantas

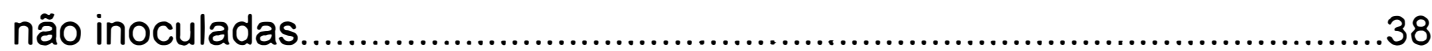

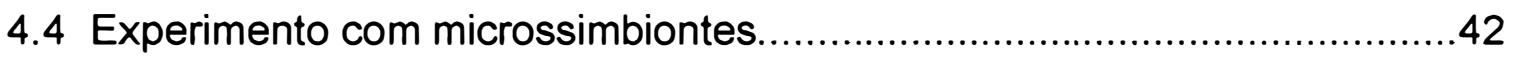

4.5 Experimento com $H$. glycines e uma única aplicação do BTH...................44

4.6 Experimento com $H$. glycines e $M$. javanica com aplicações de BTH a

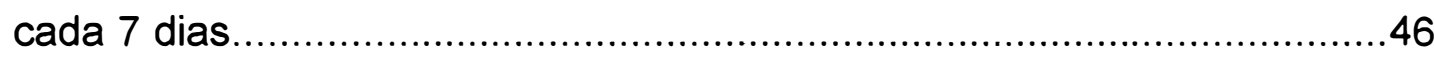

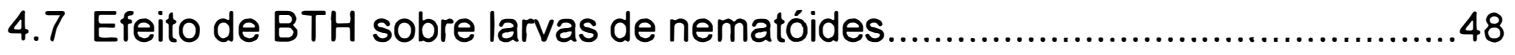

4.8 Estimativa da concentração de fitoalexinas em cotilédones de soja...........49

4.9 Estimativa da concentração de compostos fenólicos em tecidos de soja.

4.10 Extração de proteínas e eletroforese de isoenzimas...............................51

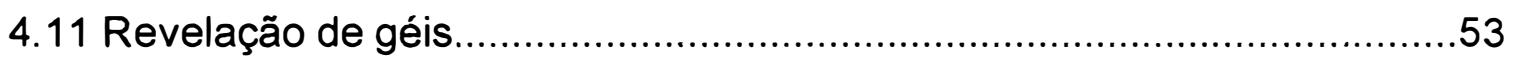

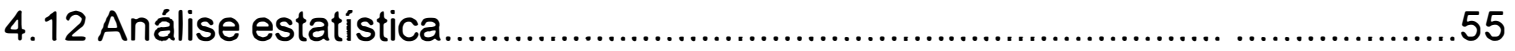

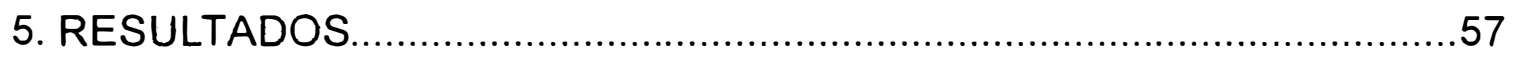

5.1 Efeito de BTH $250 \mathrm{mg} / \mathrm{L}$ no desenvolvimento vegetativo da soja..............57

5.2 Efeito de BTH $25 \mathrm{mg} / \mathrm{L}$ no desenvolvimento vegetativo da soja.................58

5.3 Efeito dos microssimbiontes e de BTH no desenvolvimento

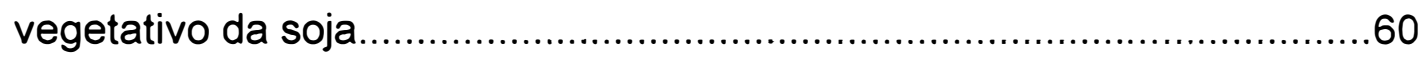

5.4 Efeito de dose única de BTH e de Heterodera glycines no desenvolvimento vegetativo da soja.

5.5 Efeito de cinco aplicações de BTH em doses crescentes e dos nematóides $H$. glycines e $M$. javanica sobre o desenvolvimento vegetativo da soja......

5.6 Efeito de BTH na colonização de raízes da soja por microssimbiontes mutualísticos..

5.7 Efeito de BTH na infecção de soja por nematóides. .75

5.8 Influência de BTH na mobilidade de larvas de $H$. glycines e $M$. javanica. 
Página

5.9 Efeito de BTH no acúmulo de fitoalexinas em cotilédones de soja.............79

5.10 Efeito de BTH no acúmulo de compostos fenólicos em tecidos de soja,

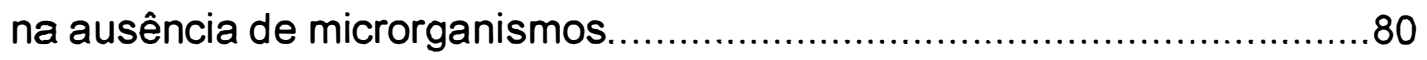

5.11 Efeito de BTH e da colonização por microssimbiontes mutualísticos e no acúmulo de compostos fenólicos em tecidos de soja.

5.12 Influência de BTH no padrão eletroforético de isoenzimas presentes em tecidos de soja.

6 DISCUSSÃO

7 CONCLUSÕES.

8 ANEXO. 108 


\section{LISTA DE ABREVIATURAS}

$\begin{array}{ll}\text { dap } & \text { dias após o plantio } \\ \text { DIECA } & \text { dietilcarbamato de sódio } \\ \text { DBO } & \text { demanda bioquímica de oxigênio } \\ \text { DTT } & \text { ditiotreitol } \\ \text { EDTA } & \text { etilenodiaminatetraacetato } \\ \text { MTT } & \text { 3-(4,5-Dimetiltiazol-2-il)-2,5-Difeniltetrazólio brometo } \\ \text { NBT } & \text { nitro blue tetrazólio } \\ \text { NEM } & n \text { - ethylmaleimide } \\ \text { PMSF } & \text { phenylmethylsulfonyl fluoride } \\ \text { PVP } & \text { Polyvinyl pirrolidone } \\ \text { TEMED } & \text { N,N, } N^{\prime}, N^{\prime} \text {-Tetrametilenodiamina } \\ \text { Tris } & \text { Tris (hidroximetil) aminometano }\end{array}$




\title{
EFEITO DO BTH NA EXPRESSÃO DIFERENCIAL DE ISOENZIMAS E NA INTERAÇÃO DE MICROSSIMBIONTES E NEMATÓIDES FITOPATOGÊNICOS COM PLANTAS DE SOJA
}

\author{
Autora: LÚCIA VIEIRA HOFFMANN \\ Orientadora: Profa. ELKE J. BRAN NOGUEIRA CARDOSO
}

\section{RESUMO}

Os efeitos das interações da soja com microssimbiontes e com nematóides fitopatogênicos têm relevância para o ganho econômico desta cultura. O ativador de defesa vegetal BTH, também conhecido com o nome comercial de Bion, pode vir a ser recomendado para aplicação em soja.

Existem evidências de semelhanças entre os processos de colonização de plantas por patógenos e por microssimbiontes. Então, a aplicação de produtos que ativam os mecanismos de proteção às doenças, como $\circ \mathrm{BTH}$, pode inibir também as simbioses. A aplicação do BTH não teve efeito sobre a colonização de raízes de soja por Glomus intraradices mas reduziu a intensidade de colonização por Bradyrhizobium japonicum quando aplicado via radicular.

O efeito do BTH na colonização pelos nematóides do cisto da soja (Heterodera glycines) e de galhas da soja (Meloidogyne javanica) foi testado. A incubação com o produto nas concentrações de $0,25,50,100$ e $250 \mathrm{mg} / \mathrm{L}$ não teve efeito na mobilidade de juvenis de segundo estádio, nem alterou o número 
de galhas causadas por elas em raízes de tomate. BTH reduziu os níveis de infecção por $H$. glycines em raízes de soja quando aplicado no solo a 25, 125 e 250 mg/L. Cinco aplicações do BTH a 25, 50 or 100 mg/L reduziram o nível de infecção por $M$. javanica. O tratamento com BTH provocou fitoxicidade. Portanto, o efeito da aplicação do produto no solo sobre a intensidade de colonização de raízes associado a ausência de efeito direto do produto sobre os juvenis sugere que uma reação de defesa da planta foi estimulada pelo BTH.

Para testar o efeito do BTH na expressão de isoenzimas, o produto foi aplicado às folhas e raízes de soja na concentração de $25 \mathrm{mg} / \mathrm{L}$ do ingrediente ativo. Os extratos de raízes das plantas que foram tratadas com BTH via radicular apresentaram duas bandas mais intensas e três bandas adicionais quando revelados na presença de guaiacol, o-dianizidina ou catecol, comparados aos extratos de plantas controle. As mobilidades relativas das isoformas foram consistentes, sugerindo que uma mesma enzima é funcional para os três substratos. Como guaiacol é considerado substrato específico de peroxidase, e o-dianizidina e catecol são substratos de peroxidases, esta enzima é provavelmente uma peroxidase de substrato inespecífico (EC 1.11.1.7). Peroxidases são marcadores bioquímicos de resistência sistêmica adquirida, mecanismo de ação do BTH nas espécies modelos tabaco e Arabidopsis thaliana.

Os perfis eletroforéticos de quitinases e superóxido dismutases de folhas ou raízes não foram alterados pelo BTH. 
A aplicação foliar de BTH não teve efeito na colonização de raízes por

B. japonicum ou sobre o perfil eletroforético de peroxidases. Portanto, o produto é absorvido de maneira mais eficiente quando aplicado via radicular, ou não é translocado de parte aérea para raiz. 


\title{
EFFECT OF BTH ON ISOENZYME EXPRESSION AND ON INTERACTION OF
} MICROSYMBIONTS AND PATHOGENIC NEMATODES WITH SOYBEAN

\section{PLANTS}

\author{
Author: LÚCIA VIEIRA HOFFMANN \\ Adviser: Prof. ELKE J. BRAN NOGUEIRA CARDOSO
}

\section{SUMMARY}

Plant interactions with the microsymbionts rhizobia and arbuscular mycorrhiza fungi and with plant pathogenic nematodes do affect the economic performance of soybean. The protection compound BTH, also known by the commercial name Bion, if applied to soybeans, could interfere with this interactions in a positive or negative way.

Some features are shared between colonisation pathways by pathogens and microsymbionts. Therefore, the application of products that activate protection mechanisms, like BTH, could also inhibit mutualistic symbionts. BTH treatment had no effect on the colonization of soybean roots by Glomus intraradices but reduced Bradyrhizobium japonicum colonization intensities, if applied through roots.

The effect of BTH on Heterodera glycines (soybean cyst nematode) and Meloidogyne javanica (Javanese root-knot nematode) was evaluated. Incubation in the product at $0,25,50,100$ and $250 \mathrm{mg} / \mathrm{L}$ had no effect on the mobility of second-stage juveniles of both species, neither affected the number of galls 
caused by them on tomato roots. BTH reduced the infection levels by $H$. glycines in soybean roots when applied to soil at 25,125 e $250 \mathrm{mg} / \mathrm{L}$. Five applications of BTH at 25,50 or $100 \mathrm{mg} / \mathrm{L}$ reduced infection levels by $M$. javanica. BTH treatments provoked phytotoxicity. The absence of a direct effect on the nematodes, although causing restriction of the root infection levels suggests that a plant resistance reaction is stimulated by BTH.

To test the effect of BTH on isoenzyme expression, the product was applied to soybean roots and leaves at the dose of $25 \mathrm{mg} / \mathrm{L}$ of the active ingredient. Root extracts of plants were examined for enzyme activity after electrophoresis in polyacrylamide native gels. The gels from plants to which BTH had been applied via the roots, revealed two more intense and three additional bands when stained using guaiacol, o-dianizidine or catechol, compared to gels from the controls. The relative mobilities of the isoforms were consistent for the three substrates, suggesting that the same enzyme is functional with all of them. This enzyme is probably a peroxidase with a unspecific substrate (EC 1.11.1.7), since guaiacol is considered a specific substrate for peroxidases and catechol and o-dianizidine are peroxidase substrates, although unspecific. Peroxidases are biochemical markers of systemic acquired resistance, a mechanism by which BTH protects the model plants tobacco and Arabidopsis from pathogens.

Electrophoretic profiles of chitinase and superoxide dismutase extracted from leaves or roots on native alkaline gels were not altered by BTH. 
Applications of BTH to leaves had no effect on root colonisation by $B$. japonicum neither on electrophoretic profiles of peroxidases from roots extracts. Therefore, BTH absortion is more effective when applied by roots then by leaves, or else, neither the product itself nor an activated plant signal is translocated from leaves to roots. 


\section{INTRODUÇÃO}

A soja estabelece interações com patógenos e com dois microssimbiontes muito importantes para soja e outras culturas, que são rizóbios e fungos micorrízicos arbusculares. A relevância econômica da cultura ressalta, ainda, mais um motivo para torná-la um modelo para estudo dessas interações.

Entre os agentes patogênicos mais importantes estão os nematóides da galha (Meloidogyne javanica) e o nematóide do cisto (Heterodera glycines). Estima-se que as perdas causadas pela ação de nematóides em lavouras de soja variam entre $8,5 \%$ e $40 \%$ (Wrather et al., 1997; Todd, 1993).

Todo o nitrogênio necessário para o desenvolvimento da soja é obtido através da fixação do $N_{2}$ atmosférico, o que é feito por bactérias, conhecidas como rizóbios, que se associam às raízes da soja. A espécie mais importante em soja é Bradyrhizobium japonicum.

A soja também realiza simbiose com fungos micorrízicos arbusculares. Estes fungos atuam aumentando o volume de solo explorado pelo sistema radicular da planta, auxiliando na absorção de nutrientes, em especial do fósforo, que possui pequena mobilidade no solo. 
O contato com patógenos pode estimular plantas a ativar mecanismos de resistência, tornando-as mais resistentes a novas infecções, sendo esta resistência de amplo espectro. A resistência induzida pode manifestar-se não apenas no local de contato com o patógeno, mas em toda a planta. 0 mecanismo de resistência sistêmica induzida melhor caracterizado é chamado de resistência sistêmica adquirida (do inglês, "systemic acquired resistance", SAR).

Agentes abióticos também podem ser indutores de SAR. O exemplo mais estudado é o ácido salicílico (SA), que ocorre no citoplasma das células vegetais, e atua como sinal intermediário na indução de transcrição das proteínas que caracterizam este mecanismo de resistência. O composto sintético "benzol-(1,2,3)-thiadiazole-7-carbothioic acid S-methyl ester", chamado também de benzotiadiazole ou BTH é outro indutor abiótico de SAR (Friederich et al., 1996; Görlach et al., 1996; Lawton et al., 1996) e vem sendo comercializado na Europa, com o nome de Bion ${ }^{\circledR}$, para aplicação em cereais de inverno. No Brasil, este produto está na fase de registro, com o mesmo nome comercial.

A manifestação de SAR dá-se por ativação da transcrição de genes, o que resulta na formação de novas proteínas que podem ser usadas para a caracterização bioquímica da resistência. As proteínas induzidas podem variar entre espécies, mas ainda não foi feita a sua caracterização em soja.

Existem evidências de semelhanças fisiológicas e genéticas entre as vias de colonização por patógenos e por microssimbiontes mutualísticos. Assim, 
a aplicação de produtos que ativam os mecanismos de proteção às doenças da plantas, como o BTH, poderia inibir também os processos de colonização por microssimbiontes, o que não seria desejável. Dada a importância das simbioses mutualísticas para a cultura da soja, a redução de sua eficiência poderia resultar em danos de relevância econômica. 


\section{OBJETIVOS}

Os objetivos deste trabalho foram:

i) Analisar o efeito da aplicação de BTH sobre a intensidade de colonização por dois patógenos (Heterodera glycines e Meloidogyne javanica) e dois microssimbiontes mutualísticos (Bradyrhizobium japonicum e Glomus intraradices) nas raízes da soja.

ii) Identificar um marcador bioquímico que permita diferenciar plantas que receberam ou não a aplicação de BTH.

iii) Comparar o efeito da aplicação de BTH via pulverização foliar com a aplicação de solução no solo (via raízes). 


\section{REVISÃO DE LITERATURA}

\subsection{As interações entre microrganismos e plantas}

As plantas estão constantemente expostas a grande variedade de microrganismos. No entanto, apenas pequena parte deles especializou-se, durante a evolução, na interação com as plantas.

Considerando que o fato de haver interação entre espécies não necessariamente significa contato direto entre organismos envolvidos ou alterações morfológicas ou fisiológicas, pode-se afirmar que, de maneira geral, conhece-se muito pouco sobre quais espécies de microrganismos interagem com plantas, como se dá a interação e qual a sua importância.

O solo é um reservatório de diversidade de espécies microbianas, que entram em contato com as plantas via raiz. A nivel de solo, as plantas são importantes para grande número de espécies microbianas, uma vez que, na maior parte do tempo, o solo é pobre em carbono orgânico, que é fonte de energia para a maioria dos microrganismos, os quimiorganotróficos, que ficam então em inanição (Cardoso e Freitas, 1992). Neste contexto, as raízes são a 
principal fonte de matéria orgânica e, consequentemente, os microrganismos ploriferam na região da rizosfera, onde há constante aporte de uma variedade de compostos orgânicos exsudados pelas de raízes (Kapulnik, 1996a). Outras alterações produzidas no solo pelas raízes também afetam os microrganismos, como absorção localizada de água e nutrientes, reumidificação e alterações físicas. Assim, a microbiota da rizosfera difere daquela em outras regiões do solo (McCully, 1999). A interação com as plantas não excede, na maioria das vezes, a colonização da superfície das raízes (Kapulnik, 1996b).

Algumas das bactérias que vivem na rizosfera promovem alterações que estimulam o desenvolvimento das plantas. Isto pode dar-se através da disponibilização do fósforo, através da solubilização de fosfatos inorgânicos pela ação de ácidos orgânicos ou pela mineralização de fosfato orgânico. As plantas podem beneficiar-se também pela produção de sideróforos ou hormônios vegetais produzidos por estas bactérias. Elas podem também ajudar na proteção a patógenos, através da produção de metabólitos tóxicos, competição por nutrientes ou indução de reação fisiológica sistêmica da planta com efeito de resistência. Estas bactérias são conhecidas como rizobactérias promotoras do crescimento de plantas (Kapulnik, 1996b). Podem também associar-se às raízes bactérias fixadoras de nitrogênio de vida livre, beneficiando as plantas através da conversão do nitrogênio atmosférico em forma assimilável (Kapulnik, 1996b).

As interações mais estudadas e conhecidas são aquelas em que ocorrem alterações morfológicas e fisiológicas nos organismos envolvidos e 
que, ao mesmo tempo, têm maior relevância econômica: a simbiose mutualística e a patogênese. As simbioses mutualísticas são definidas como uma relação na qual ocorrem alterações morfológicas e fisiológicas além de benefício dos organismos envolvidos, isto é, planta e microssimbionte, enquanto que, na patogênese, o microrganismo é favorecido em detrimento da planta.

\subsection{Micorrizas arbusculares}

As micorrizas são estruturas formadas durante a simbiose entre raízes e fungos de solo. Classificam-se em ecto, endo e ectoendomicorrizas.

Nas ectomicorrizas, o fungo, geralmente basideomiceto, forma um manto externo e desenvolve-se também nos espaços intercelulares, sem que ocorra desenvolvimento intracelular. Sua importância econômica foi relatada principalmente para espécies florestais (Bellei \& Carvalho, 1992).

Nas endomicorrizas, ao contrário, o fungo desenvolve-se intracelularmente. São divididas em três tipos distintos, sendo que os tipos ericóide e orquidóide ocorrem apenas nas famílias Ericaceae e Orquidaceae, respectivamente (Silveira, 1992). O terceiro tipo, micorrizas arbusculares, ocorrem em cerca de $80 \%$ das espécies de plantas (Bonfante \& Peroto, 1995). Os fungos que formam endomicorrizas pertencem à ordem Glomales de Zigomicetos, 
A grande gama de hospedeiros dos fungos micorrízicos arbusculares pode ser entendida considerando-se a origem muito antiga desta simbiose, que data do período Paleozóico, na mesma época em que as plantas, originalmente aquáticas, partiram para a conquista do ambiente terrestre (Simon et al., 1993). Existe, então, a hipótese de que a simbiose tenha sido auxiliar ou fundamental para que as plantas pudessem adaptar-se ao novo ambiente. $O$ grande espectro de hospedeiros é explicado pela origem antiga da simbiose com as plantas pioneiras da colonização do ambiente terrestre e a conservação dos genes responsáveis por esta associação, conforme novas espécies de plantas foram surgindo (Gianinazzi-Pearson et al., 1996).

Não se identificam plantas colonizadas por micorrizas arbusculares a olho nu, mas apenas em microscopia ótica, pela qual se observam hifas, vesículas e arbúsculos.

Os arbúsculos originam-se da penetração de células corticais pela hifa, causando invaginação da plasmalema. São os principais locais de troca de metabólitos e assim, do ponto de vista fisiológico, a principal estrutura da simbiose. Têm vida de 4 a 5 dias. Após este período sofrem degeneração, e então a célula volta a ter atividade normal (Bonfarte-Fasolo, 1984).

Vesículas são corpos globosos, inter ou intracelulares, com tamanho de 30 a $100 \mu \mathrm{m}$, que ocorrem em alguns dos gêneros dos fungos micorrízicos arbusculares. São ricas em lipídeos, o que sugere tratar-se de organelas de reserva (Bonfarte-Fasolo, 1984). Todos os fungos micorrízicos arbusculares 
formam arbúsculos, mas alguns não formam vesículas, sendo este o principal argumento para alterar a denominação de "micorrizas vesículo-arbusculares" para "micorrizas arbusculares" (Walker, 1995).

A germinação do esporo ocorre na superfície da raiz. A penetração é possibilitada pela ação mecânica e enzimática da hifa. Ocorre, então, crescimento intercelular da hifa e, finalmente, colonização intracelular, após a colonização que ocorre na epiderme ou exoderme e parênquima cortical. O cilindro central e regiões meristemáticas não são colonizados (Bonfante-Fasolo, 1984).

Não é certo qual o exsudato da planta reconhecido pelo fungo micorrízico arbuscular, ou quais os componentes do fungo são reconhecidos pela planta. Flavonóides têm sido propostos como possíveis sinais reconhecidos pelo fungo micorrízico. No entanto, não são indispensáveis para o estabelecimento da micorriza (Bécard et al., 1995).

Quando as plantas percebem a presença de um patógeno, respondem com a formação de papila, que consiste normalmente em componentes de parede celular primária e secundária, contendo compostos como calose, fenóis, proteínas e silicone. No caso da colonização por fungos micorrízicos arbusculares, as plantas mostram pouca reação, a nível citológico, à formação de apressório ou à hifa de infecção, sem que nenhuma reação marcante ocorra na parede celular das células epidérmicas ou hipodérmicas. Ocasionalmente, ocorre engrossamento das paredes das células epidérmicas no ponto de contato do apressório com algumas plantas, como alho-porró, tomate ou fumo. 
Este engrossamento é semelhante à parede celular normal quanto à textura e propriedades de coloração, não apresentando em sua composição calose ou fenóis (Gianinazzi-Pearson et al., 1996).

Assim, pode-se dizer que as plantas hospedeiras não apresentam resposta de defesa típica ao fungo micorrízico. Quando o fungo é intercelular, a parede celular do fungo e a parede celular da planta ficam em contato direto. Quando a hifas atravessam as células, a única reação é a formação de novo de membrana derivada da membrana plasmática, chamada membrana periarbuscular. Então se forma, entre planta e parede de fungo, uma região de troca de nutrientes. Neste espaço, a planta deposita material de composição semelhante à parede celular, criando a matriz fibrilar (Bonfante-Fasolo, 1984; Gianinazzi-Pearson et al., 1996; Gianinazzi-Pearson, 1996).

As células da planta, contendo arbúsculos, sofrem diminuição no tamanho de vacúolos, aumento do volume do citosol e aumento no número de organelas (mitocôndrias, plastídeos, retículo endoplasmático e de Golgi). O núcleo aumenta de tamanho e migra para o centro da célula. Quando o arbúsculo chega à fase de senescência, o núcleo, o citoplasma e o vacúolo voltam ao aspecto anterior ao da colonização (Gianinazzi-Pearson, 1996).

Bonfante-Fasolo (1984) sugere que o material depositado na interface entre fungo e planta, nos locais em que as hifas atravessam as células, é de origem da planta, em função da continuidade entre esta interface e a parede celular. Como evidência desta hipótese, Bonfante-Fasolo et al. (1990) demonstraram, em raízes de Allium porrum, inoculadas com Glomus 
versiforme, através de imunocitoquímica, que celulose e componentes pécticos presentes exclusivamente na parede celular da planta estavam também presentes no material de interface.

\subsection{Rizóbio e a interação simbiótica com leguminosas}

O termo rizóbio agrupa bactérias dos gêneros Rhizobium, Azorhizobium, Bradyrhizobium e Sinorhizobium. Associam-se a plantas da família leguminosa, também chamada Fabaceae, e são capazes de fixar nitrogênio atmosférico, convertendo-o em formas aproveitáveis pelas plantas. Esta associação é responsável pela fixação de pelo menos 35 milhões de toneladas de nitrogênio por ano. Revisões sobre esta interação foram feitas por Freire (1992), Long (1996) e Pawlowski \& Bisseling (1996).

$\mathrm{Na}$ interação entre rizóbios e leguminosas formam-se estruturas radiculares chamadas nódulos, onde ocorre fixação de nitrogênio atmosférico. $\mathrm{Na}$ presença de exsudatos de raiz de plantas leguminosas ocorre ploriferação das bactérias, que aderem à planta hospedeira na região dos pelos radiculares. Se houver compatibilidade entre planta e microssimbionte, ocorre encurvamento do pelo radicular. A bactéria penetra através do cordão de infecção. Quando chega em células hipodérmicas, ocorre divisão acelerada destas células (hiperplasia) e também crescimento delas (hipertrofia). A bactéria diferencia-se em bacterióide. Assim são formados os nódulos, estruturas 
organizadas contendo: i) uma camada cortical, externa; ii) uma região meristemática, apical ou circundando quase todo o nódulo; iii) região vascular e endoderme e iv) uma área fixadora, central ou apical (Freire, 1992).

Na região central, dentro do bacteróide, ocorre a fixação de nitrogênio, ou seja, a conversão de nitrogênio atmosférico em amônia, segundo a reação:

$$
\mathrm{N}_{2}+6 \mathrm{H}^{+}+6 \mathrm{e}^{-} \rightarrow 2 \mathrm{NH}_{3}
$$

Esta reação é endergônica e se utiliza da energia da célula bacteriana, armazenada na forma de ATP. Esta reação é catalizada pela enzima nitrogenase, a única enzima capaz de quebrar a ligação tripla covalente entre os dois átomos de nitrogênio e presente em todos os organismos diazotróficos. Esta enzima é sensível ao oxigênio, que pode destruí-la irreversivelmente. Assim, os organismos aeróbicos fixadores de nitrogênio desenvolveram várias estratégias de proteção da enzima ao oxigênio. No caso dos nódulos de rizóbio, a proteção se dá através da leg-hemoglobina, uma proteína com alta afinidade pelo oxigênio, capaz de liberá-lo para o bacterióide em baixas concentrações, suficientes para a respiração mas nunca prejudiciais à nitrogenase (revisto por Neves \& Rumjaneck, 1992).

Os sinais que mediam a interação de plantas com rizóbios são conhecidos: a planta exsuda flavonóides que, percebidos pelo rizóbio induzemno a ativar os genes Nod, sendo que vários codificam enzimas responsáveis pela biossintese dos fatores Nod, que são lipo-oligossacarídeos. Estes lipooligossacarídeos são sinais para as plantas, que, na sua presença, ativam 
genes que codificam proteinas responsáveis pelo processo de nodulação (encurvamento de pelo radicular, formação do cordão de infecção, hiperplasia e hipertrofia de células) e estabelecimento do nódulo.

$\mathrm{Na}$ interação entre rizóbio e leguminosa, existe especificidade entre hospedeiro e microssimbionte, explicada por dois modelos (Long, 1996). No primeiro modelo, a especificidade deve-se ao reconhecimento ou não dos exsudatos da planta pela bactéria, que induz ou não os genes Nod. Este modelo foi verificado nas interações entre Lotus e Rhizobium loti e Phaseolus e $R$. etli. Lotus pode ser colonizado por $R$. loti mas não por $R$. etli mas, uma vez induzida a expressão constitutiva de genes Nod em $R$. etli, a colonização ocorre. No segundo modelo, a especificidade deve-se aos lipooligossacarídeos. Foi demonstrado em alfafa, que induz expressão de genes Nod tanto em $R$. meliloti como em $R$. leguminosarum bv. Viceae. No entanto, apenas $R$. meliloti nodula a alfafa.

\subsection{Nematóides fitopatogênicos e a interação com plantas}

Embora geralmente microscópicos, os nematóides não podem ser considerados microrganismos por possuírem organização em tecidos.

Os nematóides causadores de doenças de plantas podem ser migratórios ou sedentários, endo ou ectoparasitos. Provavelmente, a partir de parasitas de fungos, evoluíram os ectoparasitos migratórios e, a partir destes, 
surgiram os endoparasitos sedentários, grupo mais especializado e de maior importância econômica (Sijimons et al., 1994). Entre os endoparasitos sedentários estão os nematóides formadores de galhas (gênero Meloidogyne) e os nematóides de cistos (incluindo os gêneros Heterodera e Globodera). Revisões recentes sobre estes patógenos foram realizadas por Cohn et al. (1996); Gheysen et al. (1996); Sijmons et al. (1994); Williamson \& Hussey (1996).

Os nematóides precisam orientar-se no solo em busca de alimentos e, para isto, possuem órgãos sensores. São atraídos por $\mathrm{CO}_{2} \mathrm{e}$, possivelmente, também por compostos solúveis exsudados pelas raízes. É também por estímulo da planta que se dá a eclosão dos ovos no gênero Heterodera (Cohn et al., 1996).

Tanto em Heterodera como em Meloidogyne são larvas juvenis de segundo estádio (J2) que eclodem dos ovos e penetram as raízes, predominantemente através das zonas de elongação e migram pela raiz até se localizar numa célula que consistirá em seu sítio permanente de alimentação. Ainda juvenis, as fêmeas começam a nutrir-se, o volume de seus corpos aumenta, ocorre perda da musculatura de locomoção e não são mais capazes de deixar a raiz. Os machos não fitoparasitos, mediante metamorfose voltam a ser vermiformes e móveis quando adultos, podendo buscar fêmeas para acasalar (Sijmons et al., 1994).

A célula nutridora da planta hospedeira, no caso do parasitismo por nematóides do gênero Heterodera, é formada por um processo de dissolução 
das paredes celulares e fusão de células vizinhas, sendo chamada sincício. Plantas parasitadas por Meloidogyne formam uma célula nutridora através de repetidas divisões celulares sem citocinese, chamada célula gigante. Apesar de processos de formação diferentes, as células nutridoras formadas por ambos os gêneros são semelhantes, pois são hipertrofiadas e polinucleadas, contendo citoplasma denso e granuloso (Gheysen et al., 1996).

No caso dos nematóides de cistos, com a morte da fêmea, a parede de seu corpo forma a proteção para os ovos que, retidos nos úteros, podem permanecer viáveis por muitos anos (Williamson \& Hussey, 1996).

O controle de nematóides fitoparasitos baseia-se principalmente em rotação de culturas e cultivares resistentes ou tolerantes. Os nematicidas disponiveis são biocidas de ação geral, altamente tóxicos. Por este motivo, alguns não são mais comercializados e outros podem ser aplicados ao solo e não às plantas por serem fitotóxicos. A introdução de resistência genética é uma boa forma de controle, embora nem sempre estejam disponiveis cultivares resistentes ou mesmo genes que confiram resistência. Freqüentemente, os genes conhecidos conferem resistência apenas para raças dos patógenos (Duncan, 1991; Trudgill, 1991).

A transformação genética possibilita introdução a muitas culturas de novos genes de resistência. Neste sentido, tem-se avaliado a resistência conferida por genes que codificam proteínas tóxicas aos nematóides ou por proteinas citotóxicas com síntese controlada por promotores induzidos pelos nematóides (Gheysen et al., 1996). 
A produção de fitoalexinas pode ser um mecanismo de resistência. Gossipol e outros aldeídos terpenóides relacionados são considerados fitoalexinas por serem tóxicos a fungos, além de serem tóxicos a insetos. Demonstrou-se que a inoculação de algodão com Meloidogyne incognita provocou aumento de concentração destas substâncias em um cultivar resistente e diminuição em um cultivar suscetível, sugerindo haver uma função fisiológica destas fitoalexinas na resistência ao nematóide (Veech \& McClure, 1977). Em soja, houve acúmulo de gliceolina após infecção por M. incognita em cultivares resistentes mas não nos suscetíveis (Kaplan et al., 1980).

O gene Mi, encontrado originalmente em tomate selvagem e introduzido pelo melhoramento no tomate cultivado, confere resistência a $M$. incognita, $M$. javanica, $M$. arenaria e alguns isolados de $M$. chitwood. Confere também resistência a afídeos. Permanece desconhecido o mecanismo pelo qual um único gene confere resistência a tantas espécies. Nas plantas resistentes, como nas suscetíveis, os nematóides penetram nas raízes e migram para o cilindro vascular. No entanto, nas plantas que contêm o gene $\mathrm{Mi}$, a célula nutridora nâo se desenvolve. Ao invés disto, no local onde estiver a larva, forma-se uma lesâo necrótica. Assim, diz-se que a resistência se deve a uma reação hipersensitiva da planta. As larvas morrem ou deixam as raízes (Williamson, 1998).

Foram feitos extratos de proteínas de raiz de linhas quase isogênicas de tomateiro, contendo ou não o gene $M i$, que confere resistência a $M$. incognita. Demonstrou-se aumento de atividade de peroxidase total em 
decorrência da infecção pelo nematóide, sendo este aumento maior nas linhagens resistentes. Nestas, ocorreu aumento de atividade de uma isoforma de peroxidase aniônica, que não ocorreu nas linhagens suscetíveis (Zacheo et al., 1993).

Poucos trabalhos na literatura relacionam um mecanismo induzido de resistência em plantas e a resistência a nematóides. Em um cultivar de soja resistente a $M$. incognita, mas suscetível a $M$. arenaria, houve diminuição de reprodução de $M$. arenaria, medida com base nos números de galhas e massas de ovos, quando duas semanas antes foi feita inoculação da planta com $M$. incognita (Ibrahin \& Lewis, 1986).

A natureza sistêmica de um mecanismo de resistência ativado efetivo na proteção de plantas contra nematóides foi demonstrada em tomateiro, onde a pré-inoculação com uma espécie incompatível de nematóide (Meloidogyne incognita) reduziu o número de ovos produzido pela espécie compatível $M$. hapla. A inoculação de $M$. incognita foi feita em uma parte da raiz fisicamente separada da parte em que foi feito o desafio com a espécie compatível $M$. hapla, assim demonstrando que a proteção é sistêmica (Ogallo \& McClure, 1996).

Um gene de catalase, cuja transcrição era ativada durante a infecção pelo nematóide do cisto Globodera pallida, foi clonado. Em plantas não inoculadas detectou-se expressão do RNA mensageiro em caule, raízes e tubérculos. Durante a infecção por G. pallida, houve indução de transcrição não só na raiz, como também no caule e folha, mostrando ser uma indução 
sistêmica. Houve indução de transcrição do mesmo gene também em decorrência de infecção pelo nematóide Meloidogyne incognita e pelas bactérias Enwinia carotovora e Corynebacterium sepedonicum, assim como por injúria e por ácido acetil salicílico. A indução sistêmica, a inespecificidade do agente indutor e a indução por ácido acetil salicílico indicam que esta isoforma de catalase pode ser um marcador de SAR (Niebel et al., 1995).

Embora, na ausência de Meloidogyne incognita, um cultivar resistente e um suscetível de soja não apresentassem diferença quanto à atividade da enzima quitinase, no cultivar resistente houve maior atividade total e indução de três isoformas ácidas da enzima, que não ocorreram no cultivar suscetível (Qiu et al, 1997).

\subsection{Interfaces entre relações simbióticas mutualísticas e patogênicas entre plantas e microrganismos}

Quando colonizadas por microrganismos, as plantas promovem alterações morfológicas e fisiológicas que dependem da regulação gênica e síntese de proteínas.

Uma vez que a sobrevivência da planta é favorecida pelo simbionte mutualístico e prejudicada pelo patógeno, espera-se que, durante o contato com um simbionte, as alterações promovidas pela planta sejam no sentido de criar um nicho adequado. Ao contrário, se for um patógeno, as alterações 
devem ser no sentido de evitar a colonização. Com efeito, em micorrizas arbusculares, as plantas em que está estabelecida a simbiose caracterizam-se por apresentar baixo nível de expressão das mesmas enzimas cuja síntese é ativada nas células das plantas após contato com patógenos. Entretanto, durante o início do processo de colonização (Azcón-Aguilar \& Barea, 1996; Dumas-Gaudot et al., 1996; Gianinazzi-Pearson, 1996) existe reação de defesa da planta.

Especula-se que as semelhanças entre a reação das plantas na presença de simbiontes mutualísticos e patógenos podem ser evidência de que as simbioses mutualísticos evoluiram a partir de relações patogênicas. Fungos (Knogge, 1996) e nematóides (Sijmons et al, 1994) fitopatogênicos evoluíram a partir de espécies sem hospedeiro específico para aquelas altamente especializadas que, ao mesmo tempo, causam maior dano. Simbiontes podem ser considerados o grau mais evoluído do parasitismo pois, além de se beneficiarem da interação com o hospedeiro, favorecem sua sobrevivência.

Curiosamente, alguns mutantes para não nodulação de ervilha e alfafa são resistentes também à colonização por fungos micorrízicos, mostrando que mecanismos genéticos comuns controlam passos nas duas diferentes simbioses (Duc et al., 1989). Em um dos mutantes de ervilha o crescimento do fungo Glomus intraradices é limitado por deposição de materiais na região de contato, de maneira semelhante ao que ocorre durante o mecanismo de resistência a fungos patogênicos. Isto não ocorre no parental selvagem, no qual se observa o desenvolvimento normal da simbiose. A natureza deste material 
foi estudada. Encontraram-se fenóis (Gollotte et al., 1993) e calose (Gollotte et al, .1995) nestas deposições, indicativos de uma reação de defesa.

A reação de defesa durante 0 estabelecimento de simbioses mutualísticas pode ser também decorrente de uma necessidade da planta de restringir a colonização. Em plantas leguminosas mutantes, que não regulam o número de nódulos, ocorre o fenótipo de supernodulação. As partes aéreas destes mutantes apresentam crescimento reduzido, demonstrando que, na supernodulação, o rizóbio é um parasita (revisto por Pawlowski \& Bisseling, 1996).

Rizóbios mutantes não eficientes também induzem reação e defesa (Spaink, 1995).

Micorrizas arbusculares são um método de controle biológico de patógenos, cuja eficiência varia muito, em função das espécies envolvidas, bem como de condições ambientais (Azcón-Aguilar \& Barea, 1996; Dumas-Gaudot et al., 1996). O estímulo de reações de defesa das plantas no início da colonização é visto como um possível mecanismo responsável pela sua eficiência.

A semelhança entre a reação inicial da planta, quando na presença do rizóbio, e de patógenos pode ser vista como evidência de que o rizóbio evoluiu a partir de uma relação patogênica. Outra evidência neste sentido é o fato de que mutantes nâo efetivos de rizóbio e micorrizas provocam na planta reação de defesa (Spaink,1995). 


\subsection{Indução de resistência em plantas}

O fenômeno de indução de resistência em decorrência da infecção por patógenos já era reconhecido no início do século. Beauverie ${ }^{1}$ (1901) e Ray ${ }^{2}$ (1901), citados por Kessmann et al. (1994), mostraram que estirpes atenuadas de Botrytis cinerea tornavam plantas de Begonia resistentes a estirpes altamente virulentas do fungo.

Chester $^{3}$ (1933), citado por Kessmann et al. (1994), questionava se a imunidade, tal como ocorre em animais, ocorre também em plantas. Descreveu vários processos, entre os quais proteção cruzada em viroses e antagonismo entre bactérias e fungos. Deu o nome de resistência sistêmica induzida (do inglês, "induced systemic resistance", ISR) a uma forma de resistência induzida anteriormente à infecção pelo patógeno, podendo distinguir-se da proteção cruzada devido a apresentar amplo espectro de proteção e do antagonismo, onde um processo ativo da planta está envolvido na resistência.

Ross (1961a, b) mostrou que o vírus do mosaico do fumo (TMV) induziu resistência em plantas de fumo, pois infecções subsequentes com o mesmo vírus eram reduzidas em severidade. Cunhou o termo resistência sistêmica adquirida (do inglês, "systemic acquired resistance", SAR) referindo-

\footnotetext{
${ }^{1}$ BEAUVERIE, J. Essai d'immunization des vegétaux contre de maladie cryptogamique. CR Acad. Sci. Paris. v. 133, p.107-10, 1901

${ }^{2}$ RAY, J. Les maladies cryptogamiques des végétaux. Ver. Gen. Bot. V.13, p.145-51.
} 
se à resistência induzida em partes distantes, não tratadas da planta. Para resistência induzida na mesma folha tratada com o vírus usou o termo 'local acquired resistance' (LAR). O termo SAR pode ser visto como um tipo específico de ISR (Kessmann et al., 1994) .

A resposta hipersensitiva (do inglês "hypersensitive response", HR) consiste na morte rápida de células em tecidos infectados por patógenos incompatíveis, sendo, portanto, uma característica de resistência do hospedeiro. A ocorrência de HR está freqüentemente associada à ativação de SAR (Dangl, 1996).

\subsection{Resistência sistêmica adquirida}

O espectro de proteção em SAR é amplo, no entanto não abrange todos os patógenos. O modelo mais estudado é o do fumo, onde há proteção contra os fungos Phytophthora parasitica, Cercospora nicotianae e Peronospora tabacina, as viroses vírus do mosaico do fumo (TMV) e vírus da necrose do fumo (TNV) e as bactérias Pseudomonas syringae pv. tabaci e Enwinia carotovora; mas não há proteção contra Alternaria alternata ou Botrytis cinerea. Em Arabidopsis, SAR é efetiva contra TCV ("turnip crinkle virus"), Pseudomonas syringae pv. 'tomato' e Phytophthora parasitica (Ryals et al., 1996).

\footnotetext{
${ }^{3}$ CHESTER, K. S. The problem of acquired physiologicaly immunity in plants. Q. Ver. Biol. V. 8, p. 275-24, 1933.
} 
Ward et al. (1991) mostraram, em fumo, a indução de transcrição de nove famílias de genes durante a manifestação de SAR induzida por TMV: PR1, PR-2, PR-3, PR-4, PR-5, PR-1 básica, quitinase ácida classe III, PR-Q' e SAR 8.2. Não foram induzidas glucanase ou quitinase básicas e peroxidase ácida (extracelular, participante da síntese de lignina). Dois compostos foram capazes de induzir os mesmos genes induzidos por TMV. O primeiro, ácido salicílico (SA), é um composto natural que participa nas plantas da sinalização de SAR. O segundo é seu análogo sintético ácido metil-2,6-dicloroisonicotínico (INA). A indução de transcrição dos genes por TMV, SA ou INA foi simultânea à manifestação de resistência, permitindo, portanto, caracterizar AS e INA como compostos ativadores de SAR. Genes ativados durante SAR foram também caracterizados em Arabidopsis thaliana e abóbora (Kessmann et al., 1994).

Existem respostas de defesa em tecidos de plantas inoculados com patógenos, como morte celular, bomba oxidativa, deposição de calose e lignina, síntese de fitoalexinas e proteínas. Estas manifestações podem ocorrer exclusivamente no local de infecção. Os genes ou proteínas considerados característicos de SAR são aqueles expressos também em tecido não infectado, cuja expressão esteja correlacionada com a resistência adquirida (Ryals et al., 1996). Estes são bem caracterizados em fumo (Ward et al., 1991).

Os genes induzidos durante SAR variam de espécie para espécie, o que pode ser reflexo de seleção durante a evolução ou melhoramento genético para os genes mais efetivos contra os patógenos aos quais cada espécie de planta é submetida (Kessmann et al., 1994). 
A indução de resistência sistêmica em plantas nem sempre é via SAR. Pieterse et al. (1996) inocularam plantas de Arabidopsis com rizobactérias promotoras de crescimento de plantas que induziram resistência sistêmica a patógenos. No entanto, não houve acúmulo de ácido salicílico ou das proteínas de resistência consideradas marcadores moleculares de SAR. Portanto, a resistência sistêmica induzida (ISR) pode ser ativada por uma via celular de sinalização independente de SAR.

\subsection{Espécies reativas de oxigênio}

Podem ser consideradas espécies reativas de oxigênio todas as espécies resultantes da redução do oxigênio molecular. Ocorrem durante processos metabólicos normais das células de planta sadias mas, se deixadas acumular, podem tornar-se tóxicas, de forma que as células possuem enzimas que atuam em sua eliminação.

Chama-se bomba oxidativa, ou estresse oxidativo, ao aumento de produção de espécies reativas de oxigênio pelas células vegetais durante alguns processos de estresse.

O oxigênio molecular não é reativo e, portanto, o primeiro passo em sua redução requer energia, fornecida em sistemas biológicos freqüentemente pelo $\mathrm{NAD}(\mathrm{P}) \mathrm{H}$. Forma-se o radical superóxido $\left(\mathrm{O}_{2}{ }^{-}\right)$, que é reduzido a peróxido de hidrogênio $\left(\mathrm{H}_{2} \mathrm{O}_{2}\right)$, radical hidroxila $\left(\mathrm{HO}^{*}\right)$ e água, sem que sejam 
necessários novos fornecimentos de energia, bastando que o pH seja neutro a levemente ácido (Baker \& Orlandi, 1995; Lamb \& Dixon, 1997; Mehdy, 1994).

Os danos celulares causados por estas espécies incluem peroxidação de lipídeos, causadas pelo íon superóxido e, principalmente, por seu ácido conjugado, o radical hidroperóxido $\left(\mathrm{HO}_{2}{ }^{\circ}\right)$. Sua remoção é catalisada pela enzima superóxido dismutase (SOD). Também é altamente reativo o radical hidroxila. Portanto, sua meia vida é muito curta, tornando difícil o estudo de sua importância biológica. Sua formação é evitada através da ação das enzimas peroxidase e catalase (Baker \& Orlandi, 1995; Lamb \& Dixon, 1997).

Doke (1983) mostrou pela primeira vez indução de bomba oxidativa associada à resistência de plantas aos patógenos. Em tecidos de batata inoculada com uma raça incompatível de Phytophtora infestans, que provoca reação de hipersensitividade (morte celular), houve produção de $\mathrm{O}_{2}^{-}$, que não ocorreu durante infecção de raça compatível do mesmo patógeno.

Mais tarde demonstrou-se, em suspensão de células, que a produção de espécies reativas de oxigênio durante a reação de resistência de plantas a patógenos pode ser dividida em duas fases. A primeira fase é breve e ocorre como resposta à inoculação com patógenos compatíveis ou incompatíveis. A segunda fase ocorre de 1,5 a 3 horas após a infecção, exclusivamente em interações não compativeis e precede a morte celular (Baker \& Orlandi,1995). 
3.9 Marcadores bioquímicos nas interações entre plantas e microrganismos

a) Superóxido dismutase (EC1.15.1.1)

Superóxido dismutase é a enzima de nome sistemático superóxido: superóxido oxirredutase, que catalisa a reação

$$
{ }^{\cdot} \mathrm{O}_{2}^{-}+{ }^{-} \mathrm{O}_{2}^{-}+2 \mathrm{H}^{+} \rightarrow 2 \mathrm{H}_{2} \mathrm{O}_{2}+\mathrm{O}_{2} \quad \text { superóxido dismutase }
$$

$\mathrm{H}_{2} \mathrm{O}_{2}$ é removido por catalase e diversas peroxidases (Lamb \& Dixon, 1997).

Fodor et al. (1997) mostraram que superóxido dismutase e as enzimas glutatione redutase, glutatione S-transferase são induzidas em folhas superiores não inoculadas em fumo inoculado com TMV. As mesmas enzimas são induzidas em folhas onde é aplicado AS.

b) Peroxidase (EC 1.11.1.7)

O nome sistemático da enzima normalmente referida como peroxidase é doador:peróxido de hidrogênio oxirredutase. O doador é representado por 
várias estruturas como fenóis, aminofenóis, diaminas, indofenóis e ascorbato, mas não álcoois ou o próprio $\mathrm{H}_{2} \mathrm{O}_{2}$ (Alfenas, 1998).

$\mathrm{HO}-\mathrm{OH}+\mathrm{HO}-\mathrm{R}-\mathrm{OH} \rightarrow 2 \mathrm{H}_{2} \mathrm{O}+\mathrm{O}=\mathrm{R}=\mathrm{O}$

peroxidase

Assim, diversas substâncias podem ser utilizadas para a revelação de isoenzimas de peroxidase. Escolhem-se substâncias que forneçam produtos coloridos quando oxidadas, assim permitindo a visualização de bandas no gel. Catecol, por vezes usado como substrato para revelar géis de polifenoloxidase, também é substrato de peroxidase (Macko et al., 1967). Dianizidina é reagente geral para hemeproteínas, incluindo peroxidase, catalase e polifenoloxidase (Alfenas et al., 1998). Benzidina (van Loon, 1971) e guaiacol (Rudolph \& Stahmann, 1964) são substratos recomendados para distinguir peroxidases de outras enzimas.

Peroxidases de parede celular são responsáveis pelo último passo da biossintese de lignina, que é a polimerização oxidativa de ácidos cinâmicos, como também são responsáveis por gerar $\mathrm{H}_{2} \mathrm{O}_{2}$ para este processo, a partir de NADH (Goldberg et al., 1985).

É bastante documentada a relação de peroxidases com resistência a doenças. Em linhas quase isogênicas de cevada resistente e suscetível a Erysiphe graminis f. sp. hordei, agente etiológico do mildio, ocorre formação de papila nos locais de infecção. Demonstrou-se que uma isoforma de peroxidase, 
também induzida em ambas as linhas (portanto relacionada a resistência não específica), localizou-se na papila. Esta isoforma deve ser responsável pela decomposição de compostos fenólicos nesta região (Scott-Craig et al., 1995).

Em fumo transformado com gene de invertase, caracterizaram-se as alterações das plantas transgênicas como manifestação de SAR, entre elas o incremento da atividade de peroxidase (Hebers et al., 1996). Em abóbora o aumento de atividade de peroxidases é considerado marcador de SAR (Strobel et al., 1996; Zhang et al., 1996).

Em feijão houve aumento da atividade de peroxidases em decorrência da aplicação de BTH (Siegrist et al., 1997).

\section{c) Quitinase (EC 3.2.1.14)}

Quitinases são as enzimas responsáveis pela hidrólise da quitina, polímero linear de $\beta(1 \rightarrow 4)-N$-acetil glucosamina. A quitina faz parte da parede celular de fungos, protozoários, aracnídeos, insetos, crustáceos e nematóides (Trudel \& Asselin, 1989). Quitinases de plantas existem nas formas ácida, normalmente localizadas nos espaços intercelulares, e básica, normalmente localizadas nos vacúolos. Sua ação está relacionada a i) liberação de oligossacarídeos das paredes de fungos que podem servir como elicitores de outros mecanismos de defesa da planta e ii) ação direta sobre a parede celular dos fungos (Pascholati e Leite, 1995). 
Em soja, houve indução de isoformas específicas de $\beta$-1,3-glucanase e quitinase mediante inoculação com o fungo Phytophtora megasperma f. sp. glycinea (Yi \& Hwang, 1996). Houve alteração de expressão ao nível de isoformas, embora a atividade total tenha permanecido inalterada.

\subsection{Indução química de SAR}

SAR é um mecanismo de proteção de plantas contra patógenos que pode ser ativada por patógenos ou compostos químicos. A resistência conferida deve-se à expressão dos genes característicos. A indução de SAR, por exemplo através da aplicação de produtos químicos em campo ou técnicas genéticas que permitam expressão maior destes genes, pode ser usada como técnica agronômica (Uknes et al., 1996).

Um composto pode ser considerado um ativador de SAR se induzir proteção aos mesmos patógenos e ativar os mesmos genes ativados em SAR, sem ter atividade antimicrobiana por si mesmo (Kessmann et al., 1994).

AS e INA são ativadores de SAR (Ward, 1991). Outros possíveis ativadores de SAR foram estudados, tendo-se em vista seu uso em campo, ao nível comercial (revisto por Kessmann et al., 1994; Lamb et al., 1992). Recentemente, vem sendo estudado o composto sintético CGA-245 704, o "benzol-(1,2,3)-thiadiazole-7-carbothioic acid S-methyl ester", também chamado 
benzotiadiazole, ou BTH (Friedrich et al., 1996; Görlach et al., 1996; Lawton et al., 1996). O produto está sendo comercializado com o nome de Bion ${ }^{\circledR}$, sendo recomendado para cereais de inverno, na Europa. No Brasil está em fase de registro, com o mesmo nome comercial. Nos Estados Unidos está também em fase de registro, com o nome comercial de Actigard. A estrutura química deste composto assemelha-se a de AS e a de INA, como mostra a Figura 1.

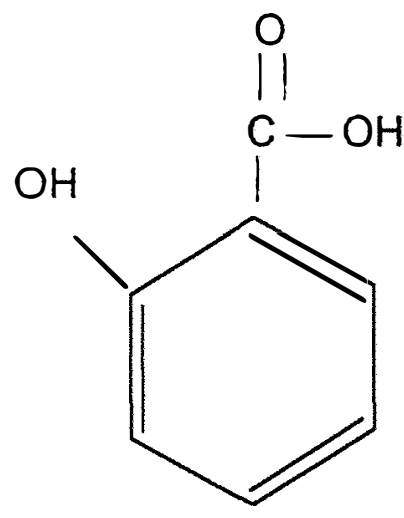

AS

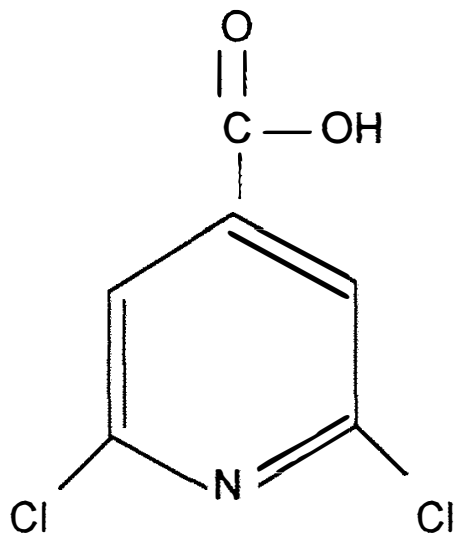

INA

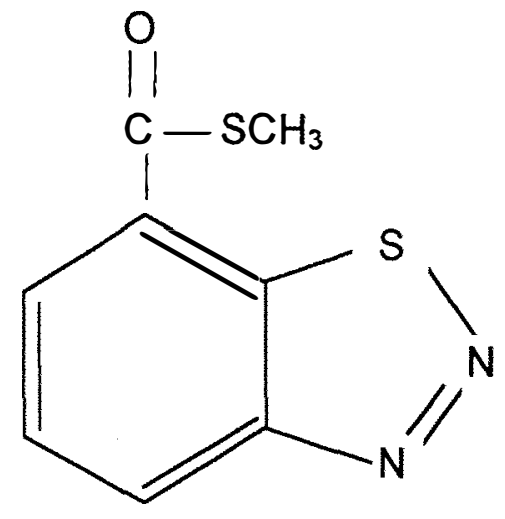

BTH

Figura 1: Comparação entre os compostos indutores de SAR : AS, INA e BTH.

O AS induz SAR apenas nos tecidos tratados, pois é rapidamente convertido a um glicosídeo, que é imóvel, enquanto que INA e BTH são eficientemente translocados por tecidos da planta. Ainda, demonstrou-se que AS e INA apresentam fitotoxicidade em algumas espécies, o que não foi feito no caso de BTH (Friedrich et al., 1996). 


\subsection{A indução de SAR por BTH}

O composto BTH induz resistência contra patógenos em plantas. Quais seriam os mecanismos de indução? Uma hipótese é de que a indução se dá através da mesma via de transdução de sinal que induz SAR, expressando portanto, os mesmos genes característicos de SAR. Diversas são as evidências neste sentido:

i) O espectro de proteção fornecido pela aplicação do produto abrange os mesmos patógenos para os quais há proteção em SAR: em Arabidopsis a aplicação de BTH conferiu proteção a TCV (turnip crinkle virus), Pseudomonas syringae pv 'tomato' e Peronospora parasitica (Lawton et al., 1996). Em plantas de fumo tratadas com BTH houve indução de proteção para Cercospora nicotianae, Erwinia carotovora, Phytophthora parasitica, Pseudomonas syringae pv. tabaci, Peronospora tabacina e TNV; no entanto não houve proteção contra Alternaria altemata ou Botrytis cinerea. Curiosamente, em fumo, BTH induz resistência a TMV em plantas suscetíveis, ao contrário do que acontece com outros indutores de SAR (Friedrich et al., 1996).

ii) Friedrich et al. (1996) relataram que não houve restrição de crescimento micelial in vitro decorrente da adição de BTH ao meio de cultura, na concentração de $282 \mathrm{mg} / \mathrm{L}$, em 18 espécies de fungos testadas (Alternaria brassicae, A. brassicola, Botrytis cinerea, Ceratocystis ulmi, Cladosporium cucumerinum, Fusarium culmorum, Helminthosporium oryzae, $H$. teres, Mucor 
hiemalis, Penicillium digitatum, P. expansum, P. italicum, Phytophthora infestans, Pyricularia oryzae, Rhizoctonia solani, Septoria nodorum, Ustilago maydis e Verticillium dahliae). Esta observação levou os autores a afirmar que BTH não tem atividade antifúngica in vitro, e que, portanto, o efeito de restrição de colonização por patógenos em plantas tratadas provavelmente deve-se à ativação de propriedades de defesa da planta. Os autores ressaltaram que não se pode excluir que o produto possa agir sinergicamente com um componente não identificado da planta, adquirindo então propriedade antibiótica, mas que isto seria difícil, pois não há precedente de um composto simultaneamente com atividade antifúngica, antibacteriana e antiviral. Entretanto, embora a concentração utilizada por estes autores tenha sido suficiente no controle de doenças da espécie com que trabalharam, o fumo, para outras espécies pode ser baixa. Pascholati et al. (1998) mostraram que, na concentração de 100 ou 200mg/L, o BTH inibiu o crescimento micelial e a germinação de esporos de Colletotrichum graminicola.

iii) Em fumo, os genes cuja indução de expressão são considerados característicos de SAR (Ward et al., 1991) foram também induzidos por BTH (Friedrich et al., 1996). Em Arabidopsis thaliana o tratamento com BTH induziu transcrição de PR-1, PR-2 e PR-5, cuja expressão já havia sido relacionada a SAR (Lawton et al., 1996). Em monocotiledôneas, SAR não é bem caracterizada mas, em milho, identificaram-se cinco cDNAs induzidos por BTH, sem homologia com genes previamente descritos relacionados a SAR, mas cuja época de indução foi consistente com a manifestação de resistência a 
Erysiphe graminis f. sp. tritici. A aplicação de BTH induziu também a transcrição de gene homólogo a PR-1a de trigo (Görlach et al., 1996).

iv) Enquanto que em plantas selvagens a aplicação de BTH induz ao acúmulo de PR-1, o mesmo não acontece em mutantes de Arabdopsis nim1, que são mutantes para sinalização de SAR em um passo anterior ao acúmulo de AS (Lawton et al., 1996).

v) Mutantes do gene $I s d 6$ de Arabidopsis thaliana formam espontaneamente lesões locais, acumulam constituvamente PR-1 e são resistentes contra patógenos. Estes mutantes foram transformados geneticamente com o gene de salicilato hidrolase e, portanto, perderam a capacidade de acumular ácido salicílico e, simultaneamente, de formar espontaneamente lesões locais. Estas propriedades foram restabelecidas nestes mutantes mediante aplicação de INA ou BTH (Lawton et al., 1996). Isto mostra, de maneira bastante conclusiva, o restabelecimento da via de sinalização de indução de SAR por BTH.

vi) Etileno e jasmonato são hormônios vegetais que vêm sendo relacionados com a resposta de defesa de plantas. A inoculação com patógenos freqüentemente causa um aumento na produção de etileno, e a aplicação de etileno induz enzimas características de SAR como quitinases e glucanases, bem como de enzimas envolvidas na biossintese de fitoalexinas (Penninckx et al., 1996). Entretanto, a indução de SAR por patógenos ou INA é independente de etileno, conforme demonstrado em mutantes de $A$. thaliana insensiveis a etileno (Lawton et al., 1995). Jasmonatos atuam como indutores 
de um grande número de proteínas, entre elas inibidores de proteinase (cuja função é inibir a atividade digestiva de proteinases de muitos microorganismos), tioninas, osmotina e proteínas inibidoras de ribossomos (RIPs), que têm atividade antifúngica (Reinborthe et al., 1994). O tratamento com BTH induziu transcrição de PR-1 e resistência a Peronospora parasitica nos mutantes de $A$. thaliana etr1 e ein2, não responsivos a etileno, e jar1, insensível a jasmonato. Portanto, o efeito de BTH é independente de etileno (assim como SAR) ou jasmonato (Lawton et al., 1996). 


\section{MATERIAL E MÉTODOS}

\subsection{Tratamento químico}

O éster 2-metil benzol $(1,2,3)$ tiadiazole-7-carbônico $(B T H)$, de nome químico comum Acilbenzolar-S-methyl, foi fornecido pela Novartis na forma do produto comercial Bion 500 WG® (Schurter et al., 1987), um granulado dispersivel contendo $50 \%$ do ingrediente ativo, cujo peso molar é de 210,3 .

4.2 Manutenção dos microssimbiontes e nematóides e preparo do inóculo

a) Fungo micorrízico

O inóculo de Glomus intraradices Schenck \& Smith foi mantido em plantas de Brachiaria decumbens Stapf., em casa de vegetação. Para a inoculação, o solo dos vasos foi submetido a secagem natural, colocado em 
sacos plásticos e homogeneizado manualmente, para conseguir distribuição uniforme dos propágulos (hifas e esporos do fungo) e, em seguida, coletado com uma pá medidora com capacidade de $25 \mathrm{~mL}$, o que foi colocado em cada vaso, em região próxima à semente, na data do plantio.

\section{b) Rizóbio}

Bradyrhizobium japonicum foi mantido em placas de Petri a $4^{\circ} \mathrm{C}$ em meio de Norris, contendo $10 \mathrm{~g} / \mathrm{L}$ de manitol, $0,5 \mathrm{~g} / \mathrm{L}$ de $\mathrm{K}_{2} \mathrm{HPO}_{4}, 0,8 \mathrm{~g} / \mathrm{L}$ de $\mathrm{MgSO}_{4} \cdot 7 \mathrm{H}_{2} \mathrm{O}, 0,2 \mathrm{~g} / \mathrm{L} \mathrm{NaCl}, 0,01 \mathrm{~g} / \mathrm{L}$ de $\mathrm{FeCl}_{3} \cdot 6 \mathrm{H}_{2} \mathrm{O}$ e solidificado com $18 \mathrm{~g} / \mathrm{L}$ de ágar.

Para inoculação, as bactérias foram transferidas para meio de Norris líquido, acrescido de $10 \mathrm{mg} / \mathrm{L}$ de azul de bromotimol e colocadas em agitador orbital a $28^{\circ} \mathrm{C}$, por três dias. $\mathrm{O}$ azul de bromotimol é um indicador de $\mathrm{pH}$ que, através da mudança de coloração, serviu como indicador do crescimento. $4 \mathrm{~mL}$ da cultura bacteriana foram colocados em cada vaso, em região próxima à semente, no terceiro dia após o plantio.

\section{c) Nematóide de cisto da soja}

O inóculo de Heterodera glycines Ichinohe raça 3 foi obtido de plantas de soja da variedade Embrapa 20, infectadas e mantidas em casa de 
vegetação. Os cistos presentes no solo e as fêmeas e os cistos fixos nas raízes foram obtidos mediante lavagem sob jato forte de água sobre peneiras de malhas de $840 \mu \mathrm{m}$ e $177 \mu \mathrm{m}$ acopladas. Para extração de ovos, as fêmeas e os cistos obtidos foram macerados, com auxílio de um tubo de ensaio, sobre peneira de malha $149 \mu \mathrm{m}$. Os ovos foram coletados na peneira acoplada de malha de $25 \mu \mathrm{m}$ e utilizados para inoculação. No segundo experimento, os ovos tiveram uma purificação adicional através de centrifugação em solução de sacarose de densidade $1,1 \mathrm{~S}(454 \mathrm{~g} / \mathrm{L})$ e centrifugação por 1 minuto a $600 \mathrm{~g}$.

\section{d) Nematóide de galhas}

O inóculo de Meloidogyne javanica (Treub) Chitwood foi obtido de raízes de plantas de tomate do cultivar Rutgers, infectadas e mantidas em casa de vegetação. As raízes foram cortadas e batidas em liqüidificador por 20 s, na presença de hipoclorito de sódio $1 \%$. O material foi passado por uma peneira de malha de $840 \mu \mathrm{m}$ (para retirar pedaços de raizes) acoplada a uma peneira de malha de $25 \mu \mathrm{m}$ (para retenção de ovos). Os ovos foram lavados, coletados em água e utilizados para inoculação. 


\subsection{Ensaios envolvendo aplicação radicular e foliar de BTH em plantas não inoculadas}

Três ensaios foram conduzidos com plantas de soja [Glycine max (L.) Merril] da variedade IAC 8.2, em casa de vegetação, sem inoculação com microssimbiontes ou patógenos, com a finalidade de testar o efeito do modo de aplicação de BTH sobre o peso de matéria fresca e seca da parte aérea e da raiz, sobre o padrão eletroforético das enzimas peroxidase, polifenoloxidase, superóxido dismutase e quitinase, e sobre a concentração de compostos fenólicos. Um ensaio foi feito utilizando a concentração de $250 \mathrm{mg} / \mathrm{L}$ e dois ensaios, a concentração $25 \mathrm{mg} / \mathrm{L}$.

Foram sorteados e aplicados os seguintes tratamentos: $ו$ ) controle (sem BTH); ii) BTH via foliar, através da pulverização de $20 \mathrm{ml}$ de solução iii) BTH via raiz, colocando $20 \mathrm{ml}$ de solução no solo iv) BTH via foliar e via raiz, usando simultaneamente $20 \mathrm{ml}$ de solução na raiz e $20 \mathrm{ml}$ de solução nas folhas. As aplicações de $\mathrm{BTH}$ em raiz foram feitas no $13^{\circ}$ e $14^{\circ}$ dias após o transplantio (segundo trifólio aberto) colocando-se $10 \mathrm{~mL}$ de solução no solo, próxima ao colo da planta. Apenas no primeiro experimento, em que a concentração de $250 \mathrm{mg} / \mathrm{L}$ do BTH foi utilizada, a aplicação em raiz foi feita em uma única vez, no $18^{\circ}$ dia após o plantio, utilizando $20 \mathrm{~mL}$ de solução. Em folha, as aplicações do produto foram feitas com pulverizador manual, 13 e 14 dias após o transplantio. Como neste estádio de desenvolvimento a área foliar era pequena para reter toda a solução, a aplicação de BTH foi feita em quatro pulverizações de $5 \mathrm{~mL}$, 
com intervalos suficientes para permitir a absorção do produto antes de uma nova aplicação. Para que não houvesse diferenças entre os experimentos devido à hora do dia ou aos intervalos entre aplicações, as pulverizações foram feitas sempre, no $13^{\circ}$ dia após o plantio, às 18 horas e às 21 horas e, no $14^{\circ}$ dia após o plantio, às 8 horas e às 11 horas. Para evitar respingos das folhas no solo e conseqüente absorção simultânea via radicular, foram colocados plásticos durante a aplicação e mantidos até o final da absorção. A temperatura da casa de vegetação foi controlada e mantida no intervalo de 18 a $30^{\circ} \mathrm{C}$. As plantas foram colhidas 30 dias após o transplante para vasos. O número de repetições por tratamento, as condições de solo, a época do ano e os procedimentos adotados para germinação e processamento das amostras não foram os mesmos para todos os ensaios e estão descritas a seguir:

\section{a) Ensaio com $250 \mathrm{mg} / \mathrm{L}$ de BTH}

As sementes germinaram em caixas de areia, na casa de vegetação e, aos 5 dias, foram transplantadas para vasos de $1,6 \mathrm{~kg}$, contendo uma mistura autoclavada de areia e vermiculita na proporção 3:1 (v/v). A cada semana foram regados com 500ml de solução de Hoagland e Arnon (Sarruge, 1975) em 50\% da concentração original. Este ensaio foi conduzido de 14 de janeiro a 14 de fevereiro de 1998. Foram utilizadas 4 repetições por tratamento. 
O peso de matéria fresca de raiz foi obtido após lavagem e secagem em papel de filtro, por 2 horas. $500 \mathrm{mg}$ de folhas e raízes foram colocadas em etanol $80 \%$ para extração de compostos fenólicos. Todo o restante do material vegetal colhido foi usado para calcular a quantidade total da matéria seca da parte aérea e da raiz. Para isto, o material foi colocado em estufa com circulação de ar forçada, a $65^{\circ} \mathrm{C}$, por 48 horas. O peso de matéria fresca total e a proporção de matéria seca foram utilizados para o cálculo da matéria seca total, considerando que $500 \mathrm{mg}$ foram retiradas para a determinação de compostos fenólicos.

\section{b) Primeiro ensaio com $25 \mathrm{mg} / \mathrm{L}$ de BTH}

As sementes pré-germinadas em papel de germinação em sala com temperatura controlada a $28^{\circ} \mathrm{C}$ foram transplantadas aos 5 dias para vasos, contendo 1,6kg de mistura de solo e areia, na proporção de 3:1 (v/v), autoclavados, com adição de 2,6 g de calcário dolomítico de PRNT 131 por vaso, para elevar a saturação em bases a $70 \%$.

Os vasos foram adubados com $0,25 \mathrm{~g}$ de $\mathrm{KCl}, 0,23 \mathrm{~g}$ de superfosfato triplo, $0,25 \mathrm{~g}$ de $\mathrm{NH}_{4} \mathrm{NO}_{3}$ e $0,15 \mathrm{~g}$ de $\mathrm{MgSO}_{4}$. Este ensaio foi conduzido de 26 de fevereiro de 1998 a 2 de abril de 1998. Foram utilizadas 8 repetições por tratamento. 
A matéria fresca da parte aérea foi determinada imediatamente após o corte das plantas, e a de raiz após secagem em papel de filtro. As raízes não foram secas ao ar para evitar a biossíntese de enzimas ou produção de fenóis não presentes antes da colheita das plantas. $50 \mathrm{mg}$ de folhas e raízes de quatro plantas por tratamento foram colocadas em etanol $80 \%$, para extração de compostos fenólicos. As raízes e as partes aéreas de cada planta foram separadas em duas partes aproximadamente iguais e pesadas. Uma parte foi congelada em nitrogênio líquido e mantida a $-20^{\circ} \mathrm{C}$, para posterior análise de isoenzimas. A outra parte foi usada para determinação da proporção de peso de matéria seca da parte aérea e raiz, feita após 48 horas de secagem em estufa a $65^{\circ} \mathrm{C}$, e usado para cálculo do peso de matéria seca total de parte aérea e raiz.

\section{c) Segundo ensaio com $25 \mathrm{mg} / \mathrm{L}$ de BTH}

A pré-germinação e o preparo dos vasos foram feitos como no primeiro ensaio, com $25 \mathrm{mg} / \mathrm{L}$ de BTH. A adubação foi feita com $0,309 \mathrm{~g} \mathrm{KH}_{2} \mathrm{PO}_{4} ; 0,495 \mathrm{~g}$ $\mathrm{KCl} ; 0,755 \mathrm{~g} \mathrm{NH}_{4} \mathrm{SO}_{4} ; 5,6 \mathrm{mg} \mathrm{H}_{3} \mathrm{BO}_{3} ; 2,9 \mathrm{mg} \mathrm{CuSO}$; $.5 \mathrm{H}_{2} \mathrm{O} ; 2,0 \mathrm{mg} \mathrm{ZnSO} 4.7 \mathrm{H}_{2} \mathrm{O}$; $0,2 \mathrm{mg} \mathrm{Na} \mathrm{MoO}_{4} \cdot 2 \mathrm{H}_{2} \mathrm{O}$. Este ensaio foi conduzido de 11 de novembro a 16 de dezembro de 1998. Foram utilizadas 10 repetições por tratamento. 
Para garantir que houvesse material suficiente para extração de proteínas, a proporção de matéria seca não foi analisada. $50 \mathrm{mg}$ de folhas e raízes foram colocadas em etanol $80 \%$, para extração de compostos fenólicos.

\subsection{Experimento com microssimbiontes}

Este experimento foi conduzido para avaliar o efeito da aplicação de BTH, via foliar ou radicular, sobre a colonização da soja Cv. IAC 8.2 por dois microssimbiontes, Bradyrhizobium japonicum e Glomus intraradices. Para isso, vasos de $3 \mathrm{~kg}$ de solo, misturado a areia na proporção $3: 1(\mathrm{v} / \mathrm{v})$ e autoclavados, foram adubados com 263mg de $\mathrm{KH}_{2} \mathrm{PO}_{4}, 849 \mathrm{mg}$ de $\left(\mathrm{NH}_{4}\right)_{2} \mathrm{SO}_{4}, 7,2 \mathrm{mg}$ de $\mathrm{H}_{3} \mathrm{BO}_{3}, 6,0 \mathrm{mg}$ de $\mathrm{CuSO}_{4} .5 \mathrm{H}_{2} \mathrm{O}, 4,0 \mathrm{mg}$ de $\mathrm{ZnSO}_{4} .7 \mathrm{H}_{2} \mathrm{O}$ e $0,34 \mathrm{mg}$ de $\mathrm{Na}_{2} \mathrm{MoO}_{4} \cdot 2 \mathrm{H}_{2} \mathrm{O}$. Foram plantadas 4 sementes por vaso e, oito dias após, foi feito o desbaste, deixando uma planta por vaso. Os tratamentos foram organizados em esquema fatorial $5 \times 3$, isto é, foram testadas quatro formas de aplicação de BTH e um controle, associados a dois microssimbiontes e um controle. O delineamento foi inteiramente ao acaso com seis repetições por tratamento. Os tratamentos em relação ao BTH foram: i) controle (sem aplicação de BTH); ii) aplicação em sementes, que foram incubadas, por 5 horas em placa de Petri, em solução de BTH, à temperatura ambiente. A solução foi colocada de forma a cobrir cerca de $50 \%$ da área total da semente, de forma a evitar anaerobiose. As sementes dos demais tratamentos foram 
incubadas pelo mesmo período, mas em água; iii) aplicação de $20 \mathrm{~mL}$ de BTH via radicular, no segundo dia após o plantio; iv) aplicação de $10 \mathrm{~mL}$ de BTH via radicular no $18^{\circ}$ dia após o plantio e $10 \mathrm{~mL}$ no $19^{\circ}$ dia após o plantio (a data de aplicação do produto equivale a dos ensaios não envolvendo microrganismos, considerando que naqueles experimentos foi feita a pré germinação de sementes) e v) aplicação de BTH via foliar, sendo $10 \mathrm{~mL}$ no $18^{\circ}$ dia após o plantio e $10 \mathrm{~mL}$ no $19^{\circ}$ dia após o plantio. Os cuidados durante as aplicações do produto foram os mesmos já descritos para os ensaios anteriores. A concentração de BTH foi sempre de $25 \mathrm{mg} / \mathrm{L}$. Em relação ao microssimbiontes, os tratamentos foram: i) controle (plantas não inoculadas); ii) plantas inoculadas com B. japonicum, no terceiro dia após o plantio e iii) plantas inoculadas com $G$. intraradices, na data de plantio.

A coleta do material vegetal foi feita no $47^{\circ}$ dia após o plantio. As raízes foram secas em papel de filtro e pesadas. Os nódulos de cada planta foram retirados e contados. As partes aéreas, as raízes e os nódulos foram colocados em estufa com circulação de ar forçada, a $65^{\circ} \mathrm{C}$, por 48 horas, e determinado o peso de matéria seca (Nogueira,1997). As intensidades de colonização foram obtidas pelas razões entre os números de nódulos e pesos de matéria seca das raizes ou pelas razões entre o peso da matéria seca de nódulos e o peso de matéria seca das raízes.

Para a avaliação da colonização por $G$. intraradices, as raízes, secas em estufa, foram colocadas em água por 48 horas para re-hidratação e, a 
seguir, transferidas para solução fixadora contendo etanol, ácido acético, formaldeído $37 \%$ e água, na proporção $2: 0,1: 0,5: 4$ (v/v/v/v). Foi feita coloração das raízes com azul de tripano a 0,05\% (Colozzi-Filho \& Balota, 1994). Para isto, as raízes foram lavadas em água e clareadas em solução de $\mathrm{KOH}$ a $10 \%$ e aquecidas a $90^{\circ} \mathrm{C}$ por 50 min em banho maria. Foram novamente lavadas e transferidas para solução de $\mathrm{HCl} 1 \%$ por 2 min, e então para mistura de ácido láctico, glicerina e água (1:1:1) contendo azul de tripano a 0,05\%, onde permaneceram por $8 \mathrm{~min}$ a $90^{\circ} \mathrm{C}$. Foi feita observação, sob lupa, em placa de Petri que possui no fundo linhas quadriculadas. Avaliou-se a presença de estruturas do fungo (hifas, arbúsculos ou vesículas) nos pontos onde as raízes cruzam as linhas. A porcentagem de colonização foi calculada, dividindo-se o número de vezes em que as estruturas estão presentes pelo número total de observações. A intensidade de colonização foi obtida pela razão entre a porcentagem de raízes colonizadas e peso de matéria seca de raízes. Este ensaio foi conduzido de 8 de janeiro a 24 de fevereiro de 1999. A temperatura da casa de vegetação foi controlada e mantida no intervalo entre 18 e $30^{\circ} \mathrm{C}$.

\subsection{Experimento com $H$. glycines e uma única aplicação de BTH}

As sementes de soja var. IAC 8.2 foram plantadas em vasos de cerâmica que continham $1,1 \mathrm{~kg}$ de uma mistura autoclavada de solo e areia 
1:1(v/v). Em cada vaso foi colocado $1,3 \mathrm{~g}$ de calcáreo dolomítico (PRNT 131) e feita adubação com 96,5 mg KH $\mathrm{PO}_{4} ; 311 \mathrm{mg}\left(\mathrm{NH}_{4}\right)_{2} \mathrm{SO}_{4} ; 2,66 \mathrm{mg} \mathrm{H}_{3} \mathrm{BO}_{3} ; 2,18$ mg CuSO $4.5 \mathrm{H}_{2} \mathrm{O} ; 1,47 \mathrm{mg} \mathrm{ZnSO}_{4} \cdot 7 \mathrm{H}_{2} \mathrm{O}$ e $0,127 \mathrm{mg} \mathrm{Na} \mathrm{MoO}_{4} \cdot 2 \mathrm{H}_{2} \mathrm{O}$. Foram plantadas 3 sementes por vaso e, no quinto dia após o plantio, antes da inoculação, foi feito desbaste, deixando-se uma planta por vaso.

Os tratamentos foram organizados em esquema fatorial $2 \times 4$, isto é, um controle sem nematóide e $H$. glycines associados a um controle e três doses de BTH $(25,125$ e 250mg/L). A aplicação de BTH foi sempre de $20 \mathrm{~mL}$, via radicular, no segundo dia após o plantio. Foram utilizadas 8 repetições por tratamento.

A inoculação com $H$. glycines foi feita com $2 \mathrm{~mL}$ de uma suspensão contendo 4.000 ovos, colocada em furos de cerca de $2 \mathrm{~cm}$ de profundidade ao lado da raiz de cada plântula, no quinto dia após o plantio.

As partes aéreas foram colhidas aos 42 dias após o plantio e obtido o peso de matéria fresca. $50 \mathrm{mg}$ de folhas foram colocadas em etanol $80 \%$ para determinação de compostos fenólicos. Após 48 horas em estufa foi determinado o peso de matéria seca.

Para avaliar a colonização por $H$. glycines, foram coletadas as raízes e o solo aderido a elas, 3 dias após o corte da parte aérea. Nesse período o solo não recebeu água. As raízes foram lavadas sob jato forte de água sobre peneira de malha de $840 \mu \mathrm{m}$ acoplada à peneira de malha $250 \mu \mathrm{m}$. As raizes foram secas em papel de filtro para obter o peso da matéria fresca. Depois, 
$50 \mathrm{mg}$ foram separadas para extração de compostos fenólicos. O restante foi seco em estufa, por 48 horas a $65^{\circ} \mathrm{C}$, para determinar o peso da matéria seca. O material retido na peneira de malha de $250 \mu \mathrm{m}$ foi coletado em água e nele adicionado o mesmo volume de formaldeído diluído a $8 \%$, para obter a concentração final de 4\%. As fêmeas adultas de $H$. glycines foram contadas sob lupa. Este experimento foi conduzido de 26 de março a 7 de maio de 1999. A temperatura da casa de vegetação foi controlada de forma a permanecer no intervalo de 18 a $30^{\circ} \mathrm{C}$.

O nível de infecção de cada tratamento foi medido pela razão entre o número de fêmeas e o peso de matéria seca de raiz.

\subsection{Experimento com $H$. glycines e $M$. javanica com aplicações de BTH a cada 7 dias}

No segundo experimento com nematóides fitopatogênicos, utilizaramse plantas de soja da variedade Embrapa 133 que, em experimentos conduzidos no Departamento de Entomologia, Fitopatologia e Zoologia Agrícola da ESALQ/USP, de acordo com Asmus ${ }^{1}$, tem mostrado suscetibilidade aos nematóides $H$. glycines e $M$. javanica. A variedade IAC 8.2, utilizada nos ensaios anteriores, foi desenvolvida a partir da variedade IAC 8, através da incorporação, por retrocruzamento, de resistência ao cancro da haste. Espera-

\footnotetext{
${ }^{1}$ Asmus, G. L. Comunicação pessoal, 1999
} 
se, então, o mesmo comportamento para resistência a nematóides destes dois cultivares. Como foi encontrado um relato de resistência da variedade IAC 8 a M. javanica (Sharma, 1933), embora tenha sido considerada suscetivel por outros (Empresa Brasileira de Pesquisa Agropecuária, 1994), preferiu-se optar, para este estudo, pela variedade Embrapa 133.

As sementes germinaram em areia em casa de vegetação e, após seis dias, foram transplantadas para vasos de cerâmica com $1 \mathrm{~kg}$ de substrato, preparados conforme descrito para o primeiro ensaio com nematóides. 0 experimento foi inteiramente ao acaso com os tratamentos em esquema fatorial $3 \times 4$, isto é, com plantas não inoculadas ou inoculadas com os nematóides $H$. glycines ou M. javanica e com a aplicação radicular de $20 \mathrm{~mL}$ de solução de BTH nas concentrações $0,25,50$ e $100 \mathrm{mg} / \mathrm{L}$. Foram utilizadas 10 repetições por tratamento.

As plantas foram inoculadas no quinto dia após o transplante para os vasos (folha primária aberta). Para isso, foram feitos furos de cerca de $2 \mathrm{~cm}$ de profundidade em lados opostos de cada planta e aí adicionados $5 \mathrm{ml}$ de suspensão contendo 1000 ovos/mL .

A primeira aplicação de BTH foi feita no quarto dia após o transplante para os vasos (décimo dia após o plantio). Repetiu-se a aplicação a cada sete dias, sempre na mesma concentração. Foram feitas 5 aplicações de BTH por vaso até a colheita, 39 dias após o transplante.

Este experimento foi conduzido de 3 de setembro a 18 de outubro de 1999. A temperatura da casa de vegetação foi controlada de forma a 
permanecer no intervalo entre 18 e $30^{\circ} \mathrm{C}$. O período de luminosidade foi fixado em 14 horas ao dia.

A avaliação da colonização por $H$. glycines foi feita conforme já descrito no ensaio anterior e os resultados expressos pelas razões entre o número de galhas pelo peso de matéria seca de raiz. Para avaliar o nível de infecção por M. javanica, foi contado o número de galhas e calculada a razão entre o número de fêmeas e o peso de matéria seca de raiz.

\subsection{Efeito de BTH sobre larvas de nematóides}

Este experimento teve a finalidade de determinar se o produto BTH tem efeito direto sobre o estádio infectivo dos nematóides $M$. javanica e $H$. glycines.

A extração de larvas $J_{2}$ de $H$. glycines foi feita a partir de plantas de soja da variedade Embrapa 20, conforme procedimento descrito por Acedo \& Dropkin (1982). A extração de larvas $J_{2}$ de $M$. javanica foi feita a partir de plantas de tomate cultivar Rutgers. Para isto, as raízes infectadas foram colocadas na presença de Phoxine B na concentração de 15mg/L para coloração das massas de ovos presentes, então extraídas com estiletes e transferidas para funil de Bairmann modificado. As larvas eclodidas foram coletadas em Becker. Os procedimentos para extração de larvas de nematóides foram realizados por Guilherme Lafourcade Asmus, que gentilmente as cedeu para a realização deste estudo. 
Placas de Petri contendo 2.000 larvas J2 de M. javanica ou $H$. glycines e $10 \mathrm{~mL}$ de solução de BTH nas concentrações $0,25,50,100$ e $250 \mathrm{mg} / \mathrm{L}$ foram incubadas a $27^{\circ} \mathrm{C}$, no escuro. Após 24 horas, a mobilidade das larvas foi observada sob lupa e calculadas as porcentagens de larvas móveis em relação ao número total de larvas (Davis et al., 1997). Este procedimento foi feito com 4 repetições por tratamento para $H$. glycines e 3 repetições por tratamento para M. javanica. Larvas de M. javanica, em outras três placas de Petri, preparadas e incubadas nas mesmas condições por 36 horas, foram lavadas com água sobre peneira de malha de $25 \mu \mathrm{m}$, para retirada de $\mathrm{BTH}$, e inoculadas em plantas de tomate do cultivar Rutgers de $10 \mathrm{~cm}$ de altura. Estas plantas estavam em copos plásticos contendo $250 \mathrm{~mL}$ de solo, regados com $100 \mathrm{~mL}$ de solução de Hoagland e Arnon (Sarruge, 1975) e permaneceram em casa de vegetação. Após 15 dias (11/11/99 a 26/11/99) foi contado o número de galhas por planta.

\subsection{Estimativa da concentração de fitoalexinas em cotilédones de soja}

A determinação da produção de fitoalexinas foi feita em cotilédones de soja in vitro. Para determinar a produção de fitoalexinas em cotilédones, usouse o procedimento descrito por Guzzo (1989). Sementes de soja da variedade IAC 8.2 foram plantadas em areia esterilizada. Os cotilédones foram retirados 11 dias após o plantio, lavados três vezes em água destilada esterilizada, 
cortados na superfície inferior e colocados em placas de Petri sobre papel de filtro umedecido, com a superfície cortada voltada para cima. Foram então adicionadas, sobre a área seccionada, $80 \mu \mathrm{L}$ de uma das seguintes soluções: i) água destilada esterilizada (controle negativo); ii) BTH $25 \mathrm{mg} / \mathrm{L}$ iii) BTH $250 \mathrm{mg} / \mathrm{L}$ iv) Formulação comercial de fermento biológico (em tabletes) contendo Saccaromyces cerevisae, $200 \mathrm{mg} / \mathrm{mL}$ (controle positivo). As placas de Petri foram colocadas em estufa para D.B.O., no escuro, a $28^{\circ} \mathrm{C}$. Decorridas 24 horas, os cotilédones foram transferidos para tubos de ensaio contendo $2 \mathrm{~mL}$ de água destilada esterilizada e agitados durante 1 hora. A água contendo os esxudatos do cotilédone foi transferida para tubos eppendorff e foi feita centrifugação a $3026 \mathrm{~g}$, durante $30 \mathrm{~min}$. Os extratos foram então diluídos cinco vezes e foi feita uma leitura a $285 \mathrm{~nm}$ (Liu et al., 1992) por amostra, utilizandose água destilada esterilizada para ajuste da leitura zero do espectrofotômetro.

\subsection{Estimativa da concentração de compostos fenólicos em tecidos de soja}

A estimativa da concentração de compostos fenólicos foi feita utilizando folhas e raizes das plantas de soja obtidas nos experimentos conduzidos em casa de vegetação. Todas as plantas dos três experimentos que não envolveram inoculação foram utilizadas, exceto no primeiro experimento com BTH $25 \mathrm{mg} / \mathrm{L}$, quando apenas quatro das oito repetições foram utilizadas para 
extração de fitoalexinas. Foram também utilizadas as plantas não inoculadas do experimento com $H$. glycines e uma única aplicação de BTH, e todas as plantas do experimento com microssimbiontes.

O procedimento foi realizado pela primeira vez com plantas do ensaio com $250 \mathrm{mg} / \mathrm{L}$ de BTH em plantas não inoculadas com simbiontes e utilizaramse $500 \mathrm{mg}$ de folhas ou raízes maceradas em $5 \mathrm{~mL}$ de etanol $80 \%$, com almofariz e pistilo. Notou-se que $10 \%$ desta quantidade seria suficiente, de forma que em todas as extrações seguintes utilizaram-se $50 \mathrm{mg}$ de folhas, maceradas em tubos "eppendorff" com pistilo próprio.

Os macerados foram incubados por 2 horas, no caso experimentos que não envolveram inoculação, e por uma noite nos demais. Foi feita centrifugação por 10 minutos a $3026 \mathrm{~g}$ e coletado o sobrenadante. Uma diluição de 20 vezes em etanol $80 \%$ foi suficiente para ajustar a leitura em espectrofotômetro a $285 \mathrm{~nm}$ entre 0,3 e 1,2 , exceto para extratos de folha incubados durante toda a noite, para os quais a diluição foi de 40 vezes. Foi feito um extrato por planta e uma leitura por extrato.

\subsection{Extração de proteínas e eletroforese de isoenzimas}

As plantas utilizadas para extração de proteínas foram as do primeiro e segundo ensaios com aplicação de BTH na concentração de $25 \mathrm{mg} / \mathrm{L}$, via foliar ou radicular, não envolvendo inoculação, colhidas e armazenadas 
individualmente a $-20^{\circ} \mathrm{C}$. Em cada canaleta foi aplicado sempre extrato de uma só planta.

A extração de proteínas foi feita por maceração, em almofariz, do tecido vegetal primeiramente com nitrogênio líquido e em seguida na presença do tampão contendo $34 \mathrm{mM}$ de $\mathrm{K}_{2} \mathrm{HPO}_{4} ; 0,2 \mathrm{M}$ de sacarose; PVP-40 2,56\%; $3 \mathrm{mM}$ de DTT; $5,7 \mathrm{mM}$ de L-ácido ascórbico; 5,8mM de DIECA; 2,6mM de $\mathrm{NaHSO}_{4} \cdot \mathrm{H}_{2} \mathrm{O} ; 2,5 \mathrm{mM}$ de $\mathrm{Na}_{2} \mathrm{~B}_{4} \mathrm{O}_{7} \cdot 10 \mathrm{H}_{2} \mathrm{O} ; \quad \beta$ - mercaptoetanol $0,2 \%$, polietilenoglicol 1\% (Alfenas et al., 1991). A proporção de tecido vegetal e tampão extrator foi de 1:2. Os macerados foram transferidos para tubos "eppendorff", centrifugados a $3.026 \mathrm{~g}$ por $30 \mathrm{~min}$ a $4^{\circ} \mathrm{C}$ e coletado $\mathrm{O}$ sobrenadante.

A concentração de proteínas foi determinada conforme Bradford (1976), utilizando albumina de soro bovino como padrão.

As proteínas em sua forma nativa foram separadas sob condição alcalina segundo procedimento descrito por Davis (1964). As soluções estoque foram preparadas conforme descrito por Alfenas (1998).

Os géis ácidos para proteínas nativas foram preparados segundo procedimento descrito por Reisfield et al. (1962). 


\subsection{Revelação de géis}

\section{a) Peroxidase}

As soluções utilizados para incubação de géis para observação de peroxidases foram: i) solução contendo $15 \mathrm{mg}$ de orto-dianizidina em $30 \mathrm{ml}$ de ácido acético glacial e $10 \mu \mathrm{L}$ de $\mathrm{H}_{2} \mathrm{O}_{2}$ (Derbyshyre et al., 1990); ii) solução contendo $45 \mathrm{mg}$ de benzidina, $50 \mathrm{~mL}$ de álcool absoluto, $\mathrm{H}_{2} \mathrm{O}_{2} 1 \%, 3 \mathrm{ml}$ de ácido acético glacial e $12 \mathrm{~mL}$ de água destilada (Alfenas, 1998). iii) tampão fosfato $\mathrm{pH}$ 6,0 , contendo $\mathrm{H}_{2} \mathrm{O}_{2}$ 0,1\% e guaiacol $0,05 \mathrm{M}$ ou $0,5 \mathrm{M}$ (Ridge \& Osborne, 1970). A quantidade de proteína de raiz aplicada foi padronizada em $30 \mu \mathrm{g}$ por amostra.

Os géis foram preparados com $7 \%$ de poliacrilamida, exceto quando continham extratos de raiz e foram revelados em guaiacol. Neste caso os géis foram de poliacrilamida $10 \%$.

\section{b) Polifenoloxidase}

A revelação de géis para observação de polifenoloxidase foi feita em tampão fosfato de sódio $0,1 \mathrm{M}(\mathrm{pH} 7,2)$ adicionado de catecol $0,072 \%(\mathrm{p} / \mathrm{v}), \mathrm{N}, \mathrm{N}$ dimetil-p-fenil-diamida $0,072 \%(\mathrm{p} / \mathrm{v})$, e tiouréia $0,072 \%(\mathrm{p} / \mathrm{v})$ (Alfenas et al., 1991). A quantidade de proteína de raiz aplicada aos géis foi padronizada em $60 \mu \mathrm{g}$ por amostra. 


\section{c) Superóxido dismutase}

Para a observação de superóxido dismutase os géis foram revelados, na presença de luz, em solução contendo riboflavina 0,004\% (p/v); $\mathrm{Na}_{2}$ EDTA 0,3\% $(\mathrm{p} / \mathrm{v})$ e MTT 2\% (v/v) em Tris- $\mathrm{HCl}$ 0,05M pH 8,5 (Alfenas et al., 1991; Beauchamp \& Fridovich, 1971). Os géis foram de $8,9 \%$ ou $12 \%$ de poliacrilamida.

\section{d) Quitinase}

Os géis para visualização de quitinases foram preparados conforme descrito por Trudel \& Asselin (1989). Para isto, $75 \mu \mathrm{g}$ ou $10 \mu \mathrm{g}$ de proteínas de folha e $24 \mu \mathrm{g}$ de proteínas de raiz foram aplicados em cada canaleta de géis de $15 \%$ de poliacrilamida contendo quitina $0,01 \%$. Após a corrida, os géis foram incubados por $20 \mathrm{~min}$ a $37^{\circ} \mathrm{C}$ em acetato de sódio $150 \mathrm{mM}(\mathrm{pH} \mathrm{5,0)}$. Foi retirado o tampão e deixou-se revelar na estufa a $37^{\circ} \mathrm{C}$, em placa de Petri contendo papel umedecido no mesmo tampão de corrida, preparado conforme Alfenas (1998). Acrescentou-se "calcofluor white" 0,1\% em tampão Tris- $\mathrm{HCl}(\mathrm{pH} 8,9)$, e incubou-se por $4 \mathrm{~min}$ a $37^{\circ} \mathrm{C}$. Os géis foram lavados em água durante a noite e fotografados em transiluminador ultra-violeta. 


\subsection{Análise estatística}

No caso dos ensaios com tratamentos que se distinguiam pela forma de aplicação de BTH, procedeu-se à análise de variância para testar a hipótese de que os valores das variáveis em estudo eram, em média, iguais. As médias de peso de matéria fresca e seca de parte aérea e raiz foram comparadas duas a duas pelo teste de Tukey, ao nível de $5 \%$ de significância. As médias das medidas de colonização por microssimbiontes foram comparadas pelo teste de Duncan, também ao nível de $5 \%$ de significância.

No caso dos dois experimentos com nematóides, como doses crescentes de BTH foram utilizadas, optou-se por análise de regressão múltipla. As variáveis independentes foram a concentração de BTH, indicada no modelo por $[\mathrm{BTH}]$, e duas variáveis binárias, indicadas no modelo por $H$ e $M$. A variável $H$ assumia valores um (se os dados fossem relativos às plantas inoculadas com $H$. glycines) ou zero (se os dados fossem do controle ou de plantas inoculadas com $M$. javanica). Analogamente, a variável $M$ assumia os valores um (se os dados fossem relativos às plantas inoculadas com $M$. javanica) ou zero (se os dados fossem relativos ao controle ou às plantas inoculadas com $H$. glycines). Então o modelo da regressão ajustado foi:

$$
Y=a_{0}+a_{1} H+a_{2} M+b_{0}[\mathrm{BTH}]+b_{1} H[\mathrm{BTH}]+b_{2} M[\mathrm{BTH}]
$$


Cada um dos coeficientes de regressão $\left(a_{0}, a_{1}, a_{2}, b_{0}, b_{1} e b_{2}\right)$ foi comparado com zero pelo teste $t$. $O p$-valor indica a probabilidade de 0 coeficiente ser diferente de zero por acaso. Portanto, o coeficiente $b_{0}$, quando significativo, indica que a variável em estudo é função linear da concentração de BTH e, se negativo, que diminui com o aumento da concentração. Os coeficientes $a_{1}$ e $a_{2}$, se significativos, indicam que a inoculação com $H$. glycines ou $M$. javanica, respectivamente, têm efeito sobre a variável, nos tratamentos em que não receberam BTH (este efeito pode ser positivo ou negativo, conforme indicar o sinal). Os valores de $b_{1}$ e $b_{2}$, se significativos, indicam que existiu interação entre BTH e $H$. glycines ou $M$. javanica, respectivamente.

Finalmente, para verificar se a razão entre o número de fêmeas e o peso da matéria seca da raiz, no caso de $H$. glycines, ou a razão entre o número de galhas e o peso da matéria seca da raiz, no caso de $M$. javanica, são função da concentração de BTH, ajustaram-se regressões lineares simples. 


\section{RESULTADOS}

\subsection{Efeito de BTH $250 \mathrm{mg} / \mathrm{L}$ no desenvolvimento vegetativo da soja}

Uma única aplicação de BTH, na concentração de $250 \mathrm{mg} / \mathrm{L}$, foi utilizada no primeiro ensaio em casa de vegetação, em experimento não envolvendo microrganismos. A observação visual das plantas e os pesos médios da matéria fresca e matéria seca da parte aérea e da raiz, apresentados na Tabela 1, sugeriram que a aplicação radicular de BTH ou a aplicação simultânea por raiz e folhas reduziu o desenvolvimento vegetativo de plantas de soja. O teste $F$ mostrou contraste entre médias no caso de matéria fresca e seca de parte aérea, mas não no caso da raiz (Tabela I do Anexo). Os pesos de matéria fresca e seca da parte aérea foram menores quando se fez a aplicação de $B T H$ na concentração de $250 \mathrm{mg} / \mathrm{L}$ via radicular do que a mesma dose por via foliar, segundo teste de Tukey, ao nível de $5 \%$ de significância. O peso médio de matéria fresca da parte aérea das plantas que receberam BTH via foliar e radicular simultaneamente foi menor do que o controle, segundo o teste estatístico. 


\section{Tabela 1}

Médias de peso de partes aéreas e raízes de soja, 35 dias após o plantio (dap), segundo o tratamento com BTH, aplicado a $250 \mathrm{mg} / \mathrm{L}$.

\begin{tabular}{|c|c|c|c|c|c|c|}
\hline \multirow{3}{*}{$\begin{array}{c}\text { Presença ou ausência } \\
\text { de BTH e modo de } \\
\text { aplicação }\end{array}$} & \multicolumn{2}{|c|}{ Peso de parte aérea (g) } & \multicolumn{4}{|c|}{ Peso de raiz $(g)$} \\
\hline & $\begin{array}{c}\text { matéria } \\
\text { fresca }\end{array}$ & $\begin{array}{c}\text { matéria } \\
\text { seca }\end{array}$ & \multicolumn{2}{|c|}{$\begin{array}{l}\text { matéria } \\
\text { fresca }\end{array}$} & \multicolumn{2}{|c|}{$\begin{array}{c}\text { matéria } \\
\text { seca }\end{array}$} \\
\hline & $27,25 \quad a b$ & $5,79 a b$ & 19,58 & $a$ & 2,97 & $a$ \\
\hline BTH foliar, 18 e 19 dap & 33,80 & 7,82 & 22,47 & a & 3,24 & a \\
\hline BTH radicular, 18 dap & 20,39 bc & 3,73 & 11,68 & a & 1,70 & a \\
\hline $\begin{array}{c}\text { BTH foliar e radicular, } \\
18 \text { e } 19 \text { dap }\end{array}$ & 15,48 & 3,40 & 14,67 & a & 2,39 & a \\
\hline
\end{tabular}

As observações sugeriram que a concentração de BTH de $250 \mathrm{~g} / \mathrm{L}$ aplicada via radicular era alta para plantas de soja e, portanto, deveria ser utilizada, nos ensaios seguintes, uma dose mais baixa, com maior probabilidade de ser recomendada para esta cultura.

\subsection{Efeito de BTH 25 mg/L no desenvolvimento vegetativo da soja}

Os pesos médios de matéria fresca e seca da parte aérea e raiz, em dois ensaios em casa de vegetação não envolvendo microrganismos, nos quais foi realizada uma única aplicação de $B T H$, na concentração de $25 \mathrm{mg} / \mathrm{L}$, estão apresentados nas Tabelas 2 e 3.

No primeiro ensaio o teste $F$ mostrou, ao nivel de $5 \%$ significância, que existiram diferenças entre as médias de peso fresco e peso seco da parte aérea, mas não da raiz (Tabela II do Anexo). Os pesos médios de matéria 
fresca e seca das plantas às quais foi aplicado o BTH apenas via radicular foram maiores que os do controle, segundo o teste de Tukey ao nivel de $5 \%$ de significância.

\section{Tabela 2}

Médias de peso de partes aéreas e raízes de soja, 35 dias após o plantio, segundo o tratamento com BTH, aplicado a $25 \mathrm{mg} / \mathrm{L}$ no $18^{\circ}$ e $19^{\circ}$ dias após o plantio (primeiro ensaio).

\begin{tabular}{ccccccccc}
\hline $\begin{array}{c}\text { Presença ou } \\
\text { ausência de BTH e } \\
\text { modo de aplicação }\end{array}$ & \multicolumn{3}{c}{ Peso de parte aérea $\mathbf{( g )}$} & \multicolumn{4}{c}{ Peso de raiz $\mathbf{~ ( g ) ~}$} \\
\cline { 2 - 9 } & matéria fresca & matéria seca & matéria fresca & matéria seca \\
\hline Controle & 5,90 & $\mathrm{~b}$ & 1,43 & $\mathrm{~b}$ & 5,69 & $\mathrm{a}$ & 0,55 & $\mathrm{a}$ \\
BTH foliar & 6,70 & $\mathrm{ab}$ & 1,58 & $\mathrm{ab}$ & 5,91 & $\mathrm{a}$ & 0,64 & $\mathrm{a}$ \\
BTH radicular & 8,86 & $\mathrm{a}$ & 2,23 & $\mathrm{a}$ & 6,98 & $\mathrm{a}$ & 0,79 & $\mathrm{a}$ \\
BTH foliar e radicular & 7,30 & $\mathrm{ab}$ & 1,56 & $\mathrm{ab}$ & 5,84 & $\mathrm{a}$ & 0,56 & $\mathrm{a}$ \\
\hline
\end{tabular}

Nota: letras diferentes indicam que as médias são diferentes segundo o teste de Tukey ao nível de $5 \%$ de significância.

No segundo ensaio com BTH $25 \mathrm{mg} / \mathrm{L}$, aos 30 dias do transplantio, observaram-se folhas encarquilhadas em $50 \%$ das plantas de soja tratadas com BTH por via radicular e em $80 \%$ das plantas tratadas simultaneamente por via foliar e radicular. Plantas controle ou tratadas por via foliar não apresentaram o sintoma. Na Tabela 3 estão apresentados os pesos médios de matéria fresca de parte aérea e raiz. Houve efeito de tratamentos no caso do peso da matéria fresca de raiz, mas não da parte aérea (Tabela III do Anexo). O peso da matéria fresca de raiz foi maior nas plantas tratadas com BTH por via foliar do que nas plantas tratadas com BTH por via radicular ou, simultaneamente, por via radicular e foliar, segundo o teste de Tukey ao nível de $5 \%$ de significância. 


\section{Tabela 3}

Médias de peso de partes aéreas e raízes de soja, 35 dias após o plantio, segundo o tratamento com BTH, aplicado a $25 \mathrm{mg} / \mathrm{L}$, no $18^{\circ}$ e $19^{\circ}$ dias após o plantio (segundo ensaio).

\begin{tabular}{ccc}
$\begin{array}{c}\text { Presença ou ausência } \\
\text { de BTH e modo de } \\
\text { aplicação }\end{array}$ & Peso de parte aérea $\mathbf{( g )}$ & Peso de raiz (g) \\
\hline Controle & $13,99 \mathrm{a}$ & $7,386 \mathrm{ab}$ \\
BTH foliar & $16,68 \mathrm{a}$ & $9,612 \mathrm{a}$ \\
BTH radicular & $13,62 \mathrm{a}$ & $6,392 \mathrm{~b}$ \\
BTH foliar e radicular & $14,00 \mathrm{a}$ & $6,036 \mathrm{~b}$
\end{tabular}

Nota: letras diferentes indicam que as médias são diferentes segundo o teste de Tukey ao nível de $5 \%$ de significância.

\subsection{Efeito dos microssimbiontes e de BTH no desenvolvimento vegetativo da soja}

A concentração de $25 \mathrm{mg} / \mathrm{L}$ de BTH foi utilizada, em uma única aplicação, no ensaio em que foi testado o efeito de BTH na intensidade de colonização por $G$. intraradices e B. japonicum. As Tabelas 4 a 7 apresentam os pesos médios de matéria fresca e seca de parte aérea e de raiz. Para essas quatro variáveis, os valores de $F$ foram significativos e não existiu efeito da interação entre modo de aplicação de BTH e presença e espécie de microrganismo (Tabela IV do Anexo). A inoculação com G. intraradices estimulou o desenvolvimento das plantas, medido pelo aumento do peso médio de matéria fresca ou de matéria seca da parte aérea ou da raiz, segundo o teste de Tukey ao nivel de 0,05 de significância. Houve redução de matéria fresca e 
seca de parte aérea e raiz em decorrência de aplicação de BTH $25 \mathrm{mg} / \mathrm{L}$ por via radicular, segundo o mesmo teste.

\section{Tabela 4}

Peso médio de matéria fresca de partes aéreas de soja, em gramas, 47 dias após o plantio (dap), inoculada ou não com $G$. intraradices ou $B$. japonicum, segundo o modo e data de aplicação do BTH, a $25 \mathrm{mg} / \mathrm{L}$.

\begin{tabular}{|c|c|c|c|c|}
\hline \multirow{2}{*}{$\begin{array}{c}\text { Presença ou ausência de } \\
\text { BTH e modo de } \\
\text { aplicação }\end{array}$} & \multicolumn{4}{|c|}{ Presença ou ausência e espécie de microrganismo } \\
\hline & Sem inoculação & G. intraradices & B. japonicum & Média geral \\
\hline Controle & 17,17 & 26,50 & 21,47 & 21,71 \\
\hline BTH em semente & 17,12 & 27,13 & 16,60 & $20,28 a b$ \\
\hline BTH via raiz, 4 dap & 13,75 & 23,43 & 12,02 & 16,40 \\
\hline BTH via folha, 18 e 19 dap & 13,32 & 30,17 & 21,75 & 21,74 \\
\hline BTH via raiz, 18 e 19 dap & 14,88 & 28,63 & 14,28 & $19,27 \quad a b$ \\
\hline Média gera & $15,25 \mathrm{~b}$ & $27,17 \mathbf{a}$ & $17,22 \mathrm{~b}$ & 19,8 \\
\hline
\end{tabular}

Nota: letras diferentes indicam que as médias são diferentes segundo o teste de Tukey ao nível de $5 \%$ de significância.

\section{Tabela 5}

Peso médio de matéria seca de partes aéreas de soja, em gramas, 47 dias após o plantio (dap), inoculada ou não com $G$. intraradices ou $B$. japonicum, segundo o modo e data de aplicação do BTH, a $25 \mathrm{mg} / \mathrm{L}$.

\begin{tabular}{cccccc}
\hline $\begin{array}{c}\text { Presença ou ausência de } \\
\text { BTH e modo de } \\
\text { aplicação }\end{array}$ & \multicolumn{4}{c}{ Presença ou ausência e espécie de microrganismo } \\
\cline { 2 - 6 } & Sem inoculação & G. intraradices & B. japonicum & Média geral \\
\hline Controle & 3,48 & 6,22 & 4,72 & 4,81 & a \\
BTH em semente & 3,32 & 6,10 & 3,80 & 4,41 & ab \\
BTH via raiz, 4 dap & 2,60 & 4,87 & 2,52 & 3,33 & b \\
BTH via folha, 18 e 19 dap & 2,82 & 4,73 & 4,92 & 4,82 & a \\
BTH via raiz, 18 e 19 dap & 2,90 & 6,07 & 3,00 & 3,99 & ab \\
\hline Média geral & 3,02 ab & 6,00 a & 3,79 b & 4,27 \\
\hline
\end{tabular}

Nota: letras diferentes indicam que as médias são diferentes segundo o teste de Tukey ao nivel de $5 \%$ de significância. 


\section{Tabela 6}

Peso médio de matéria fresca da raiz de soja, em gramas, 47 dias após o plantio (dap), inoculada ou não com $G$. intraradices ou B. japonicum, segundo o modo e data de aplicação do BTH, a $25 \mathrm{mg} / \mathrm{L}$.

\begin{tabular}{cccccc}
\hline $\begin{array}{c}\text { Presença ou ausência de } \\
\text { BTH e modo de } \\
\text { aplicação }\end{array}$ & \multicolumn{4}{c}{ Presença ou ausência e espécie de microrganismo } \\
\cline { 2 - 6 } & Sem inoculação & G. intraradices & B. japonicum & Média geral \\
\hline Controle & 16,28 & 19,68 & 17,23 & 17,73 & a \\
BTH em semente & 15,02 & 20,80 & 13,22 & 16,34 & a \\
BTH via raiz, 4 dap & 9,57 & 14,92 & 8,92 & 11,13 & b \\
BTH via folha, 18 e 19 dap & 12,22 & 21,78 & 14,60 & 16,20 & a \\
BTH via raiz, 18 e 19 dap & 13,33 & 18,30 & 10,18 & 13,94 ab \\
\hline Média geral & 13,28 b & 19,10 a & 12,83 b & 15,07
\end{tabular}

Nota: letras diferentes indicam que as médias são diferentes segundo o teste de Tukey ao nível de $5 \%$ de significância.

\section{Tabela 7}

Peso médio de matéria seca da raiz de soja, em gramas, 47 dia após o plantio (dap), inoculada ou não com $G$. intraradices ou $B$. japonicum, segundo o modo e data de aplicação do BTH, a $25 \mathrm{mg} / \mathrm{L}$.

\begin{tabular}{cccccc}
\hline $\begin{array}{c}\text { Presença ou ausência de } \\
\text { BTH e modo de } \\
\text { aplicação }\end{array}$ & \multicolumn{4}{c}{ Presença ou ausência e espécie de microrganismo } \\
\cline { 2 - 6 } & Sem inoculação & G. intraradices & B. japonicum & Média geral \\
\hline Controle & 1,32 & 1,63 & 1,30 & 1,42 & $\mathbf{a}$ \\
BTH em semente & 1,08 & 1,67 & 0,97 & 1,24 & ab \\
BTH via raiz, 4 dap & 0,67 & 1,32 & 0,67 & 0,88 & $\mathbf{b}$ \\
BTH via folha, 18 e 19 dap & 0,88 & 1,97 & 1,17 & 1,34 & $\mathbf{a}$ \\
BTH via raiz, 18 e 19 dap & 0,93 & 1,63 & 0,82 & 1,13 & ab \\
\hline Média geral & $0,98 \mathbf{b}$ & $1,64 \mathbf{a}$ & $0,98 \mathbf{b}$ & 1,20
\end{tabular}

Nota: letras diferentes indicam que as médias são diferentes segundo o teste de Tukey ao nível de $5 \%$ de significância. 


\subsection{Efeito de dose única de BTH e Heterodera glycines no desenvolvimento vegetativo de soja}

O experimento com $H$. glycines mostrou o efeito de uma única aplicação de BTH, via radicular, nas concentrações $25,50,125$ e $250 \mathrm{mg} / \mathrm{L}$. Nas plantas tratadas, observou-se encarquilhamento das folhas (Tabela 8), que diminuiu com o desenvolvimento das plantas, e não foi mais observado na colheita do experimento, aos 42 dias após o plantio. Nesta data, mediram-se os pesos médios da matéria fresca e seca da parte aérea e da matéria seca da raiz (Tabelas 9, 11 e 13). As retas de regressão ajustadas, obtidas análise de regressão múltipla (Tabela $\mathrm{V}$ do Anexo), tendo espécie de nematóide e concentração de BTH como variáveis independentes, podem ser observadas nos gráficos das Figuras 2, 3 e 4 . Os coeficientes estão apresentados nas Tabelas 10,12 e 14 e a probabilidade de serem significativos é dada pelo $p-$ valor.

Tabela 8

Porcentagem de plantas de soja com encarquilhamento foliar, aos 20 dias após o plantio, de acordo com a concentração de BTH aplicada.

\begin{tabular}{ccc}
\hline $\begin{array}{c}\text { Concentração de BTH } \\
(\mathbf{m g} / \mathrm{L})\end{array}$ & $\begin{array}{c}\text { Plantas não } \\
\text { inoculadas }\end{array}$ & $\begin{array}{c}\text { Plantas inoculadas com } \\
\text { H. glycines }\end{array}$ \\
\hline 0 & $0 \%$ & $0 \%$ \\
25 & $13 \%$ & $14 \%$ \\
125 & $50 \%$ & $50 \%$ \\
250 & $100 \%$ & $100 \%$ \\
\hline
\end{tabular}


A inoculação com $H$. glycines não alterou o desenvolvimento da parte aérea das plantas (ver coeficientes $a_{1}$ das Tabelas 10 e 12), mas diminuiu 0 peso da matéria seca de raiz (ver coeficiente $a_{1}$ da Tabela 14).

Os pesos de matéria fresca e seca da parte aérea e de matéria seca da raiz foram função linear da concentração de BTH e decresceram com o aumento de concentração, pois o coeficiente que indica a inclinação da reta de regressão ajustada para as plantas não inoculadas foi significativo e negativo (ver coeficientes $b_{0}$ das Tabelas 10,12 e 14). Na parte aérea, o acréscimo de inclinação a ser dado às retas de regressão, no caso das plantas inoculadas com $H$. glycines (coeficientes $b_{1}$, Tabelas 10 e 12) não foram significativos, indicando que os pesos de matéria fresca e seca comportaram-se da mesma forma para plantas inoculadas ou não inoculadas. Em raiz, a inclinação da reta de regressão ajustada para plantas inoculadas com $H$. glycines foi menor que a das não inoculadas, ou seja, a diminuição de peso de matéria seca de raiz em plantas tratadas com BTH foi menos intensa nas plantas inoculadas, como mostrou o coeficiente $b_{1}$ da Tabela 14 . 


\section{Tabela 9}

Peso médio de matéria fresca da parte aérea da soja, em gramas, 42 dias após o plantio, inoculadas ou não com $H$. glycines, segundo a dose de BTH, aplicado no segundo dia após o plantio.

\begin{tabular}{ccc}
\hline $\begin{array}{c}\text { Concentração de } \\
\text { BTH (mg/L) }\end{array}$ & \multicolumn{2}{c}{ Peso de matéria fresca de parte aérea (g) } \\
\cline { 2 - 3 } & Sem inoculação & H. glycines \\
\hline 0 & 5,75 & 4,38 \\
25 & 5,45 & 5,90 \\
125 & 3,90 & 3,75 \\
250 & 2,46 & 3,24 \\
\hline
\end{tabular}

\section{Tabela 10}

Valores dos coeficientes de regressão, respectivos testes $t \mathrm{e}$ $p$ - valores para matéria fresca da parte aérea de plantas de soja (experimento com $H$. glycines e uma única aplicação de BTH).

\begin{tabular}{cccc}
\hline & Coeficiente & Valor de $\boldsymbol{t}$ & $\boldsymbol{p}$ - valor \\
\hline$a_{0}$ & 5,73 & 11,09 & 0,0000 \\
$a_{1}$ & $-0,59$ & $-0,77$ & 0,4468 \\
$b_{0}$ & $-0,013$ & $-3,63$ & 0,0006 \\
$b_{1}$ & 0,005 & 0,97 & 0,3371 \\
\hline
\end{tabular}

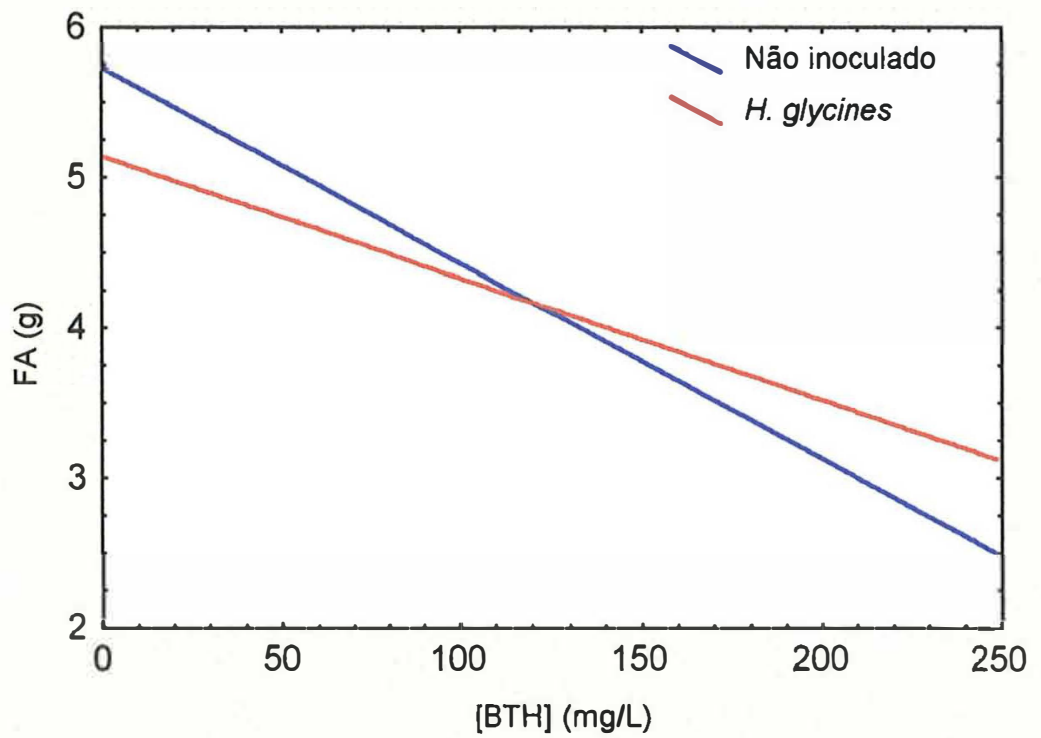

Figura 2: Peso da matéria fresca da parte aérea (FA) de plantas de soja em função da concentração de BTH ( [BTH] ) aplicado uma única vez. 
Tabela 11

Peso médio de matéria seca da parte aérea da soja, em gramas, 42 dias após o plantio, inoculadas ou não com $H$. glycines, segundo a dose de BTH, aplicado no segundo dia após o plantio.

\begin{tabular}{ccc}
\hline Concentração de & \multicolumn{2}{c}{ Presença ou ausência de $\boldsymbol{H}$. glycines } \\
\cline { 2 - 3 } BTH (mg/L) & Sem inoculação & $H \cdot$ glycines \\
\hline 0 & 1,55 & 1,29 \\
25 & 1,41 & 1,56 \\
125 & 1,03 & 0,93 \\
250 & 0,57 & 0,78 \\
\hline
\end{tabular}

\section{Tabela 12}

Valores dos coeficientes de regressão, respectivos testes $t \mathrm{e}$ $p$ - valores para matéria seca da parte aérea de plantas de soja (experimento com H. glycines e uma única aplicação de BTH).

\begin{tabular}{cccc}
\hline & Coeficiente & Valor de $\boldsymbol{t}$ & $\boldsymbol{p}$ - valor \\
\hline$a_{0}$ & 1,52 & 13,26 & 0,0000 \\
$a_{1}$ & $-0,10$ & $-0,61$ & 0,5428 \\
$b_{0}$ & $-0,0038$ & $-4,69$ & 0,0000 \\
$b_{1}$ & 0,0010 & 0,86 & 0,3922 \\
\hline
\end{tabular}

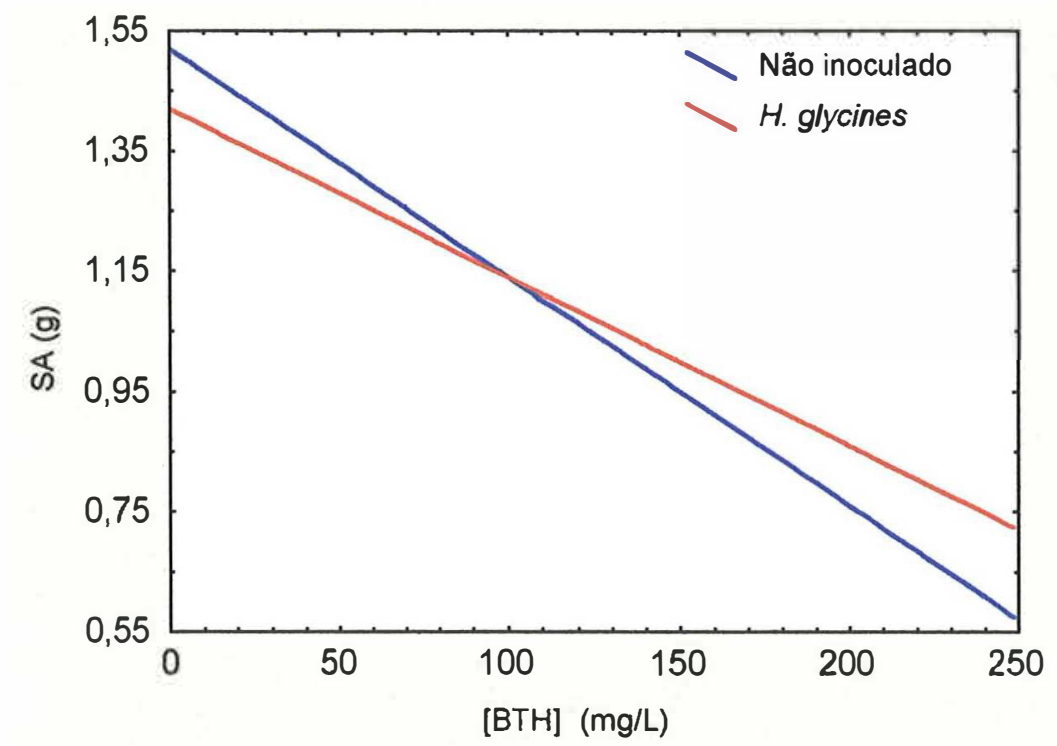

Figura 3: Peso da matéria seca da parte aérea (SA) em função da concentração de BTH ([BTH]), aplicado uma única vez. 
Tabela 13

Peso médio de matéria seca da raiz da soja, em gramas, 42 dias após o plantio, inoculadas ou não com $H$. glycines, segundo a dose de BTH, aplicado no segundo dia após o plantio.

\begin{tabular}{ccc}
\hline Concentração de & \multicolumn{2}{c}{ Presença ou ausência de $\boldsymbol{H}$. glycines } \\
\cline { 2 - 3 } BTH (mg/L) & Sem inoculação & $H$. glycines \\
\hline 0 & 1,08 & 0,37 \\
25 & 0,58 & 0,41 \\
125 & 0,44 & 0,24 \\
250 & 0,25 & 0,22 \\
\hline
\end{tabular}

\section{Tabela 14}

Valores dos coeficientes de regressão, respectivos testes $t \mathrm{e}$ $p$ - valores para matéria seca da raiz de plantas de soja (experimento com $H$. glycines e uma única aplicação de BTH).

\begin{tabular}{cccc}
\hline & Coeficiente & Valor de $\boldsymbol{t}$ & $\boldsymbol{p}$ - valor \\
\hline$a_{0}$ & 0,85 & 15,73 & 0,0000 \\
$a_{1}$ & $-0,47$ & $-5,77$ & 0,0000 \\
$b_{0}$ & $-0,0027$ & $-6,66$ & 0,0000 \\
$b_{1}$ & 0,0019 & 3,20 & 0,0023 \\
\hline
\end{tabular}

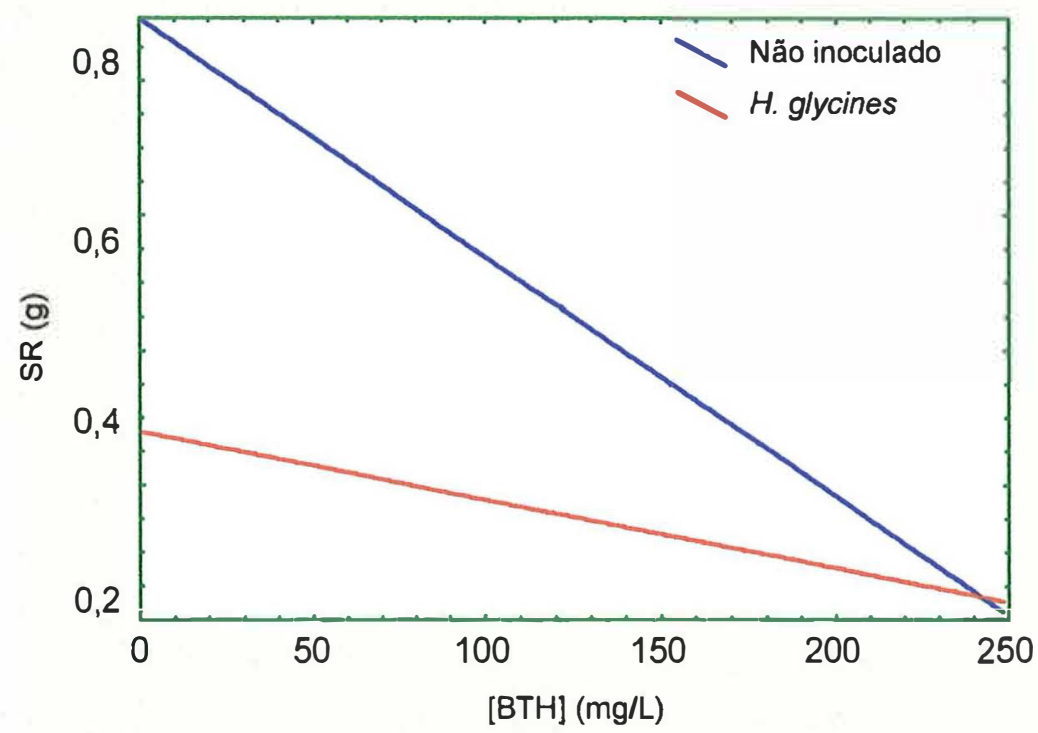

Figura 4: Peso da matéria seca da raiz (SR) em função da concentração de BTH [BTH], aplicado uma única vez. 


\subsection{Influência de cinco aplicações de BTH em doses crescentes e dos nematóides $H$. glycines e $M$. javaniva sobre o desenvolvimento vegetativo da soja.}

O experimento com $H$. glycines ou $M$. javanica foi conduzido com aplicações de BTH, via radicular, a cada sete dias, nas concentrações $0,25,50$

e $100 \mathrm{mg} / \mathrm{L}$. O encarquilhamento das folhas apareceu nas plantas tratadas e intensificou-se com o tempo, de forma que as plantas tratadas com $100 \mathrm{mg} / \mathrm{L}$ de BTH apresentaram grande redução da área foliar. Foi feita avaliação dos sintomas aos 32 dias após o plantio, quando, nas plantas tratadas, foi observada brotação de trifólio a partir do nó cotiledonar, como mostra a Tabela 15. Os pesos médios de matéria fresca e seca de parte aérea e matéria seca de raiz, aos 46 dias após o plantio, apresentados nas Tabelas 16, 18 e 20, foram submetidos à análise de regressão múltipla (Tabela VI do Anexo). Os coeficientes de regressão e os respectivos testes $t$ e $p$ - valores estão apresentados nas Tabelas 17, 19 e 21. Os gráficos das retas ajustadas podem ser observados nas Figuras 5, 6 e 7.

Os pesos de matéria fresca e seca de parte aérea não foram alterados pela presença dos nematóides. O peso médio de matéria seca de raiz, em plantas não tratadas com $\mathrm{BTH}$, foi menor nas plantas inoculadas com $M$. javanica do que nas plantas não inoculadas, como mostrou o coeficiente $a_{2}$ da Tabela 21, que foi significativo e negativo.

Os pesos de matéria fresca e seca da parte aérea e de matéria seca da raiz foram função linear da concentração de BTH e decresceram com o 
aumento de concentração, pois o coeficiente que indica a inclinação da reta de regressão ajustada para as plantas não inoculadas foi significativo e negativo (ver coeficientes $b_{0}$ das Tabelas 17, 19 e 21). Da mesma forma, as plantas inoculadas com os nematóides apresentaram redução de desenvolvimento quando tratadas com doses crescentes de BTH, pois a inclinação das retas de regressão ajustadas para as plantas inoculadas não diferiu significativamente daquela das plantas não inoculadas (coeficientes $b_{1}$ e $b_{2}$ das Tabelas $17,19 \mathrm{e}$ 21).

Tabela 15

Porcentagem de plantas de soja, aos 20 dias após o plantio, com encarquilhamento foliar e brotação de trifólio a partir do nó cotiledonar, de acordo com a concentração de BTH aplicada em plantas não inoculadas (Ni), inoculadas com $H$. glycines $(H g)$ ou com $M$. javanica $(M j)$.

\begin{tabular}{c|ccc|ccc}
\hline \multirow{2}{*}{$\begin{array}{c}\text { Concentração de } \\
\text { BTH (mg/L) }\end{array}$} & \multicolumn{3}{|c|}{ Encarquilhamento foliar } & \multicolumn{3}{c}{$\begin{array}{c}\text { Brotação a partir do nó } \\
\text { cotiledonar }\end{array}$} \\
\cline { 2 - 7 } & $\mathrm{Ni}$ & $\mathrm{Hg}$ & $\mathrm{Mj}$ & $\mathrm{Ni}$ & $\mathrm{Hg}$ & $\mathrm{Mj}$ \\
\hline 0 & 0 & 0 & 0 & 0 & 0 & 0 \\
25 & 100 & 90 & 100 & 0 & 0 & 0 \\
50 & 100 & 100 & 100 & 50 & 50 & 50 \\
100 & 100 & 100 & 100 & 100 & 100 & 100 \\
\hline
\end{tabular}




\section{Tabela 16}

Peso médio de matéria fresca da parte aérea da soja, em gramas, 45 dias após o plantio, inoculadas ou não com $H$. glycines ou $M$. javanica, segundo a dose de BTH, aplicado a cada sete dias.

\begin{tabular}{cccc}
\hline $\begin{array}{c}\text { Concentração de } \\
\text { BTH (mg/L) }\end{array}$ & \multicolumn{3}{c}{ Presença ou ausência e espécie de nematóide } \\
\cline { 2 - 4 } & Sem inoculação & H. glycines & M. javanica \\
\hline 0 & 5,02 & 4,84 & 5,28 \\
25 & 3,58 & 3,71 & 3,14 \\
50 & 3,31 & 2,81 & 2,35 \\
100 & 2,02 & 2,45 & 1,58 \\
\hline
\end{tabular}

Tabela 17

Valores dos coeficientes de regressão, respectivos testes $t$ e $p$ - valores para matéria fresca da parte aérea da soja (experimento com H. glycines e M. javanica e aplicações de BTH a cada 7 dias).

\begin{tabular}{lccc}
\hline & Coeficiente & Valor de $\boldsymbol{t}$ & $\boldsymbol{p}$ - valor \\
\hline$a_{0}$ & 4,71 & 13,60 & 0,0000 \\
$a_{1}$ & $-0,23$ & $-0,48$ & 0,6353 \\
$a_{2}$ & $-0,13$ & $-0,27$ & 0,7914 \\
$b_{0}$ & $-0,028$ & $-4,51$ & 0,0000 \\
$b_{1}$ & 0,005 & 0,58 & 0,5624 \\
$b_{2}$ & $-0,006$ & $-0,70$ & 0,4835 \\
\hline
\end{tabular}

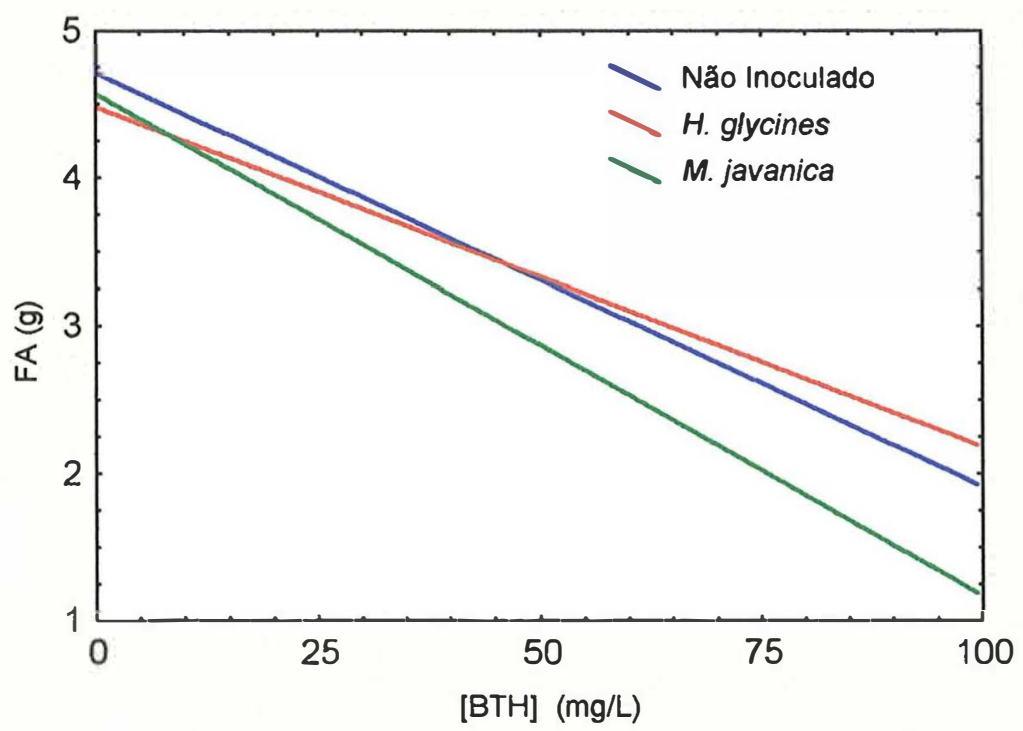

Figura 5: Peso da matéria fresca da parte aérea (FA) em função da concentração de BTH [BTH], aplicado a cada 7 dias. 


\section{Tabela 18}

Peso médio de matéria seca da parte aérea da soja, em gramas, 45 dias após o plantio, inoculadas ou não com $H$. glycines ou $M$. javanica, segundo a dose de

BTH, aplicado BTH a cada sete dias.

\begin{tabular}{cccc}
\hline $\begin{array}{c}\text { Concentração de } \\
\text { BTH (mg/L) }\end{array}$ & \multicolumn{3}{c}{ Presença ou ausência e espécie de nematóide } \\
\cline { 2 - 4 } & Sem inoculação & H. glycines & M. javanica \\
\hline 0 & 1,32 & 1,31 & 1,25 \\
25 & 0,82 & 0,82 & 0,68 \\
50 & 0,74 & 0,61 & 0,48 \\
100 & 0,42 & 0,48 & 0,30 \\
\hline
\end{tabular}

\section{Tabela 19}

Valores dos coeficientes de regressão, respectivos testes $t$ e $p$ - valores para matéria seca da parte aérea da soja, (experimento com H. glycines e M. javanica e aplicações de BTH a cada 7 dias).

\begin{tabular}{lccc}
\hline & Coeficiente & Valor de $\boldsymbol{t}$ & $\boldsymbol{p}$ - valor \\
\hline$a_{0}$ & 1,18 & 14,31 & 0,0000 \\
$a_{1}$ & $-0,04$ & $-0,36$ & 0,7159 \\
$a_{2}$ & $-1,13$ & $-1,09$ & 0,2796 \\
$b_{0}$ & $-0,0085$ & $-5,57$ & 0,0000 \\
$b_{1}$ & 0,0006 & 0,30 & 0,7684 \\
$b_{2}$ & $-0,0004$ & $-0,21$ & 0,8373 \\
\hline
\end{tabular}

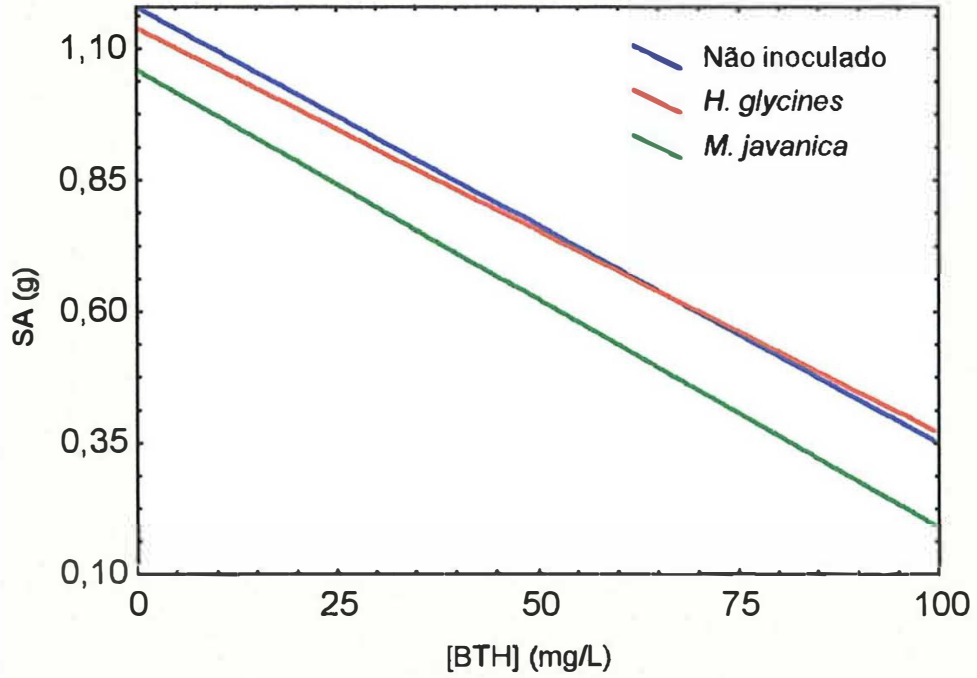

Figura 6: Peso da matéria seca da parte aérea (SA) em função da concentração de BTH, aplicado a cada 7 dias. 
Tabela 20

Peso médio de matéria seca da raiz da soja, em gramas, 45 dias após o plantio, inoculadas ou não com $H$. glycines ou $M$. javanica, segundo a dose de BTH, aplicado BTH a cada sete dias.

\begin{tabular}{cccc}
\hline $\begin{array}{c}\text { Concentração de } \\
\text { BTH }(\mathbf{m g} / \text { L })\end{array}$ & \multicolumn{3}{c}{ Presença ou ausência e espécie de nematóide } \\
\cline { 2 - 4 } & Sem inoculação & H. glycines & M. javanica \\
\hline 0 & 0,70 & 0,58 & 0,54 \\
25 & 0,38 & 0,43 & 0,23 \\
50 & 0,30 & 0,25 & 0,16 \\
100 & 0,13 & 0,21 & 0,07 \\
\hline
\end{tabular}

\section{Tabela 21}

Valores dos coeficientes de regressão, respectivos testes $t \mathrm{e}$ $p$ - valores para matéria seca da raiz da soja (experimento com $H$. glycines e $M$. javanica e aplicações de BTH a cada 7 dias).

\begin{tabular}{lccc}
\hline & Coeficiente & Valor de $\boldsymbol{t}$ & $\boldsymbol{p}$-valor \\
\hline$a_{0}$ & 0,61 & 14,66 & 0,0000 \\
$a_{1}$ & $-0,08$ & $-1,35$ & 0,1803 \\
$a_{2}$ & $-0,02$ & $-2,97$ & 0,0036 \\
$b_{0}$ & $-0,0053$ & $-7,10$ & 0,0000 \\
$b_{1}$ & 0,0016 & 1,56 & 0,1224 \\
$b_{2}$ & 0,0011 & 1,06 & 0,2918 \\
\hline
\end{tabular}

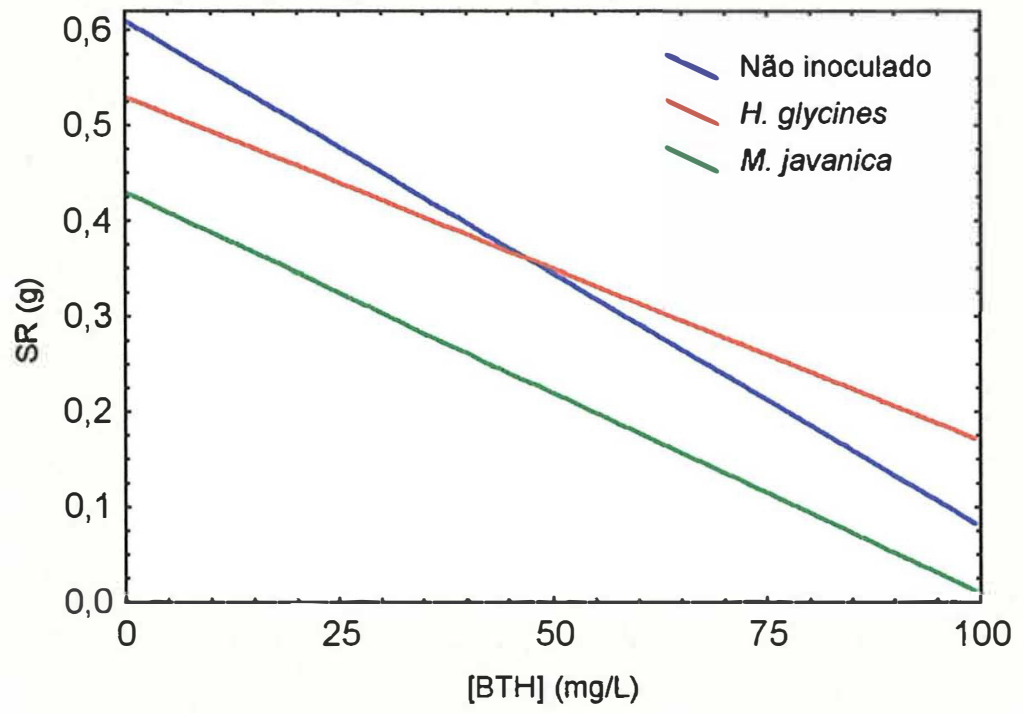

Figura 7: Peso da matéria seca de raízes (SR) em função da concentração de BTH ([BTH]), aplicado a cada 7 dias. 


\subsection{Efeito de BTH na colonização de raízes da soja por microssimbiontes mutualísticos}

A Tabela 22 apresenta os resultados do experimento conduzido para determinar se uma única aplicação de BTH teve efeito sobre a colonização por B. japonicum e G. intraradices. Neste experimento, os pesos da matéria fresca e seca da raiz diminuíram em decorrência da aplicação radicular de BTH a $25 \mathrm{mg} / \mathrm{L}$, aos 4 dias após o plantio, conforme verificado e relatado no ítem 5.3 de Resultados. Para que isto não influenciasse as possíveis diferenças entre os tratamentos, os testes estatísticos foram conduzidos utilizando dados de medidas da intensidade de colonização, dadas pelas razões entre as medidas de colonização pelos microssimbiontes e os pesos de matéria seca de raiz.

\section{Tabela 22}

Efeito da aplicação de BTH a $25 \mathrm{mg} / \mathrm{L}$ na intensidade de colonização de soja por $B$. japonicum e $G$. intraradices, aos 47 dias após o plantio (dap).

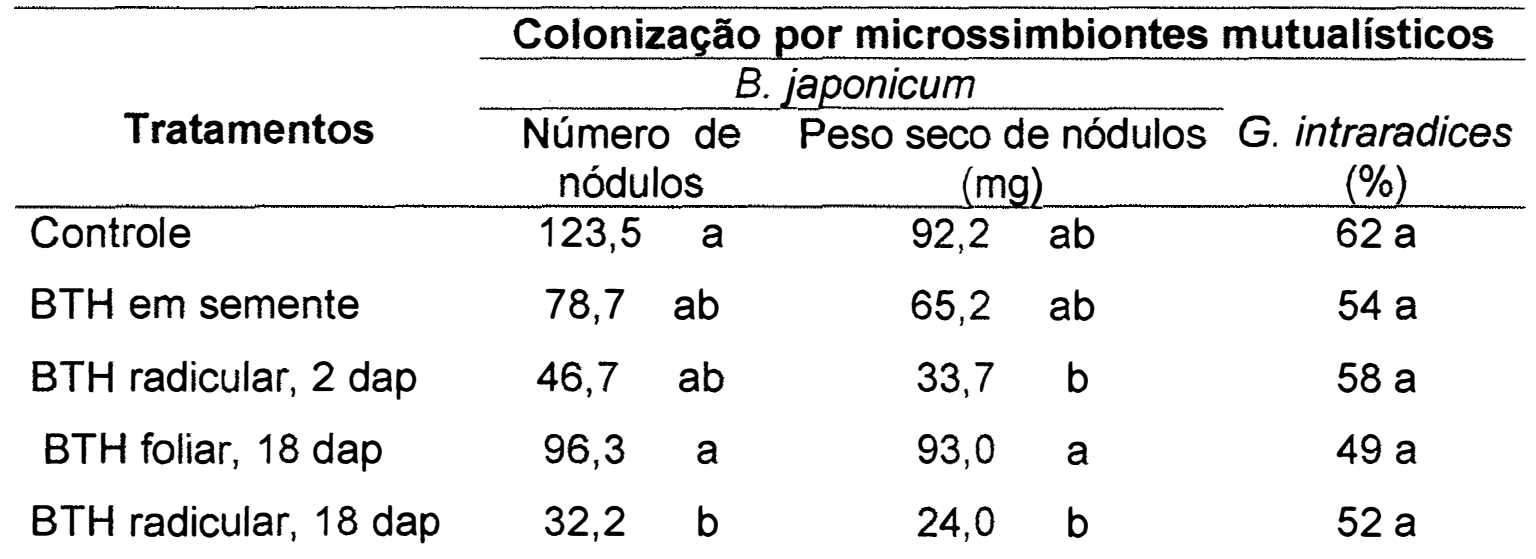

Nota: letras diferentes indicam que as razões entre as médias apresentadas na Tabela e os pesos de matéria seca de raiz são diferentes segundo o teste de Duncan ao nível de $5 \%$ de significância. 
A aplicação de BTH, na concentração de $25 \mathrm{mg} / \mathrm{L}$, teve efeito sobre a intensidade de colonização de raízes de soja por $B$. japonicum, medida pela razão entre o número de nódulos pelo peso de matéria seca de raiz e peso de matéria seca de nódulos e peso de matéria seca de raiz (Tabela VII do Anexo). As plantas tratadas com o produto por via radicular aos dezoito dias do plantio apresentaram menor razão entre o número de nódulos e o peso de matéria seca da raiz, comparativamente ao controle ou às plantas que receberam BTH via foliar, segundo teste de Duncan, ao nível de $5 \%$ de significância (Tabela 22). A razão entre peso seco dos nódulos e o peso de matéria seca de raiz foi menor nas plantas que receberam aplicação de BTH via radicular, aos 2 ou 18 dias do plantio, do que naquelas que não foram tratadas ou foram tratadas por via foliar.

O tratamento de sementes tendeu a reduzir a colonização por $B$. japonicum, embora não tenha se diferenciado do controle, segundo o teste de Duncan.

A colonização de raízes de soja por $G$. intraradices, avaliada pela razão entre a porcentagem de comprimento radicular colonizado e peso de matéria seca de raiz, não foi afetada pela aplicação de BTH na dose testada, segundo teste $F$ (Tabela VII do Anexo). 


\subsection{Efeito de BTH na infecção da soja por nematóides}

O efeito da aplicação radicular de BTH na infecção de raízes de soja por nematóides foi testado em dois experimentos. Em ambos o peso de matéria seca das raízes diminuiu com o aumento da concentração do produto, conforme foi relatado no ítem 5.4 deste Capítulo. Assim, para que a diminuição do número de fêmeas de $H$. glycines e galhas causadas por $M$. javanica não pudesse ser atribuída à redução de desenvolvimento das raízes, obtiveram-se medidas dos níveis de infecção, dados, respectivamente, pela razão entre o número de fêmeas ou o número de galhas pelo peso de matéria fresca de raiz.

O número médio de fêmeas por planta, no experimento em que a inoculação das plantas foi feita somente com $H$. glycines e o BTH aplicado uma única vez, está apresentado na Tabela 23. A Figura 8 mostra que o nível de infecção, medido pela razão entre o número de fêmeas e o peso de matéria seca de raiz, diminuiu com o aumento de concentração de BTH. Este resultado foi confirmado pela análise de variância da regressão (Tabela VIII do Anexo), que mostrou que o coeficiente de inclinação da reta ajustada foi significativo e negativo $(p=0,0320)$. 
Tabela 23

Efeito de aplicação única de BTH sobre a infecção de raízes de soja por H. glycines, no primeiro experimento.

\begin{tabular}{ccc}
\hline Tratamento & $\begin{array}{c}\text { Número médio de fêmeas por } \\
\text { planta }\end{array}$ & $\begin{array}{c}\text { Razão entre número de } \\
\text { fêmeas e peso de matéria } \\
\text { seca de raiz }\end{array}$ \\
\hline Controle & 22,8 & 61,6 \\
BTH $25 \mathrm{mg} / \mathrm{L}$ & 23,1 & 56,3 \\
BTH $125 \mathrm{mg} / \mathrm{L}$ & 9,8 & 40,8 \\
BTH $250 \mathrm{mg} / \mathrm{L}$ & 8,2 & 37,3 \\
\hline
\end{tabular}

$(\mathrm{Nf} / \mathrm{SR})=62,08-0,1284 x[\mathrm{BTH}]$

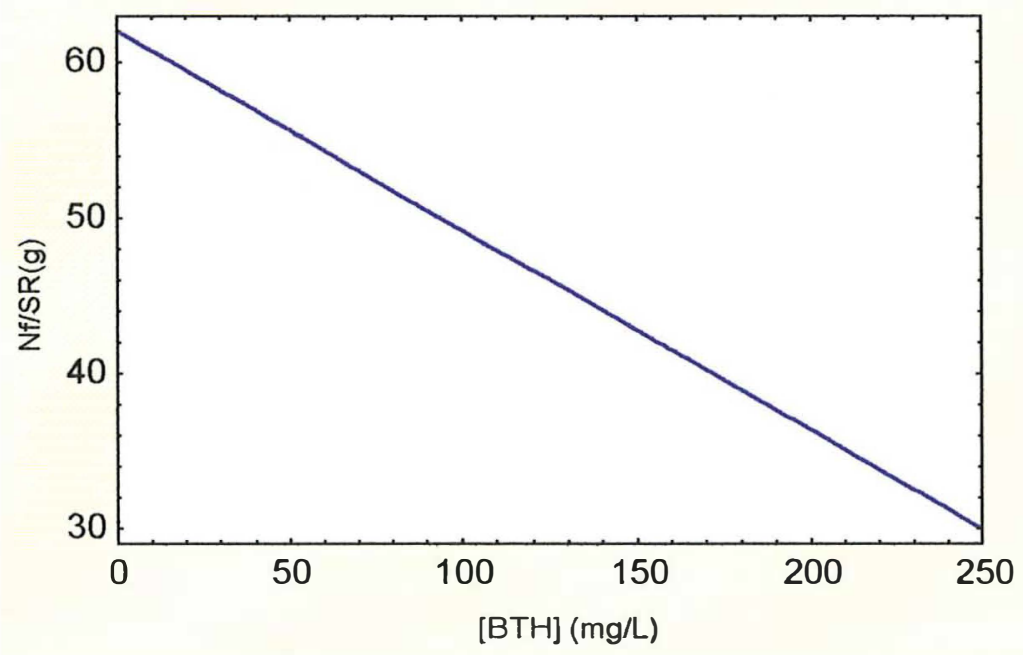

Figura 8: Reta de regressão da razão entre o número de fêmeas de $H$. glycines (Nf) e o peso de matéria seca da raiz (SR) em função da concentração de BTH ([BTH]), aplicado uma única vez.

No experimento que envolveu $H$. glycines ou $M$. javanica e em que BTH foi aplicado ao solo a cada sete dias, o nivel de infecção por $M$. javanica, estimado pela razão entre o número de galhas e o peso de matéria seca da 
raiz, diminuiu com o aumento de concentração de BTH aplicada (Figura 9). A razão foi função linear da concentração do produto e diminuiu com o aumento de concentração (Tabela IX do Anexo), pois o valor do teste $t$ foi significativo e negativo $(p=0,0132)$.

\section{Tabela 24}

Efeito de cinco aplicações de BTH sobre a infecção da soja por $H$. glycines e M. javanica, no segundo experimento.

\begin{tabular}{c|cc}
\hline Tratamento & Número de fêmeas & Número médio de galhas \\
\hline Controle & 7,6 & 160,5 \\
BTH $25 \mathrm{mg} / \mathrm{L}$ & 7,3 & 60,4 \\
BTH $125 \mathrm{mg} / \mathrm{L}$ & 2,9 & 29,2 \\
BTH $250 \mathrm{mg} / \mathrm{L}$ & 2,5 & 12,1 \\
\hline
\end{tabular}

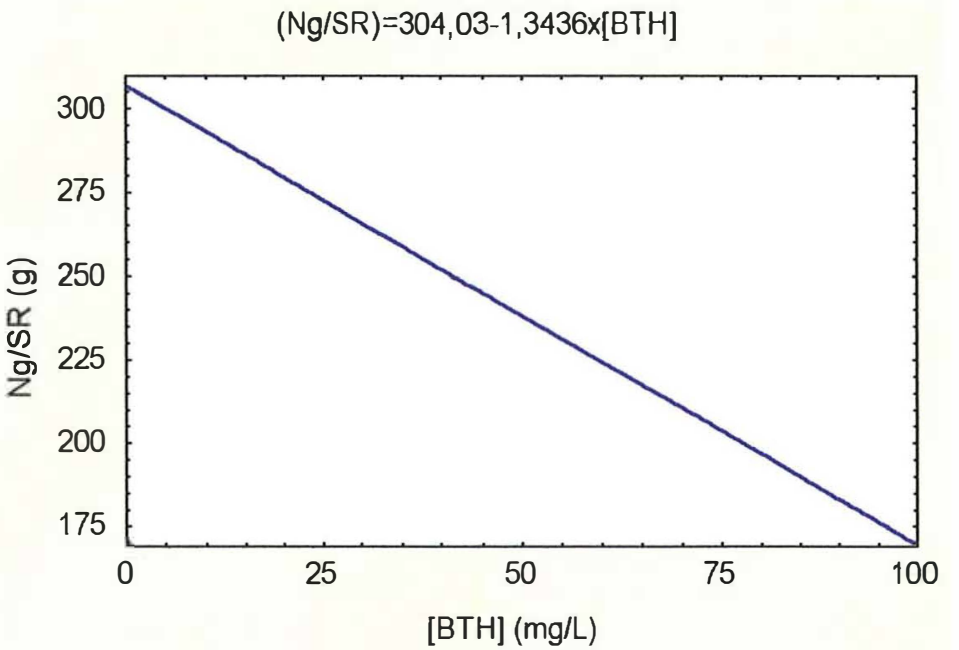

Figura 9 : Reta de regressão da razão entre o número de galhas de $M$. javanica $(\mathrm{Ng})$ e o peso de matéria seca da raiz (SR) em função da concentração de BTH ([BTH]), aplicado a cada 7 dias. 
Neste segundo experimento, o nível de infecção por $H$. glycines, medido pela razão entre o número de fêmeas e o peso seco de raiz, não mostrou redução linear com o aumento de concentração de BTH. O coeficiente que indica a inclinação da reta de regressão ajustada foi não significativo (Tabela IX do Anexo).

5.8 Influência de BTH na mobilidade de larvas de $\boldsymbol{H}$. glycines e $M$. javanica

A Tabela 25 mostra as porcentagens de larvas móveis após 24 horas de incubação in vitro na presença de BTH e o número de galhas em plantas de tomate inoculadas com larvas pré-incubadas com BTH por 24 horas.

Tabela 25

Influência de BTH sobre larvas de nematóides in vitro.

\begin{tabular}{cccc} 
Concentração do & \multicolumn{2}{c}{ Porcentagem de larvas móveis } & número de \\
\cline { 2 - 4 } BTH (mg/L) & H. glycines & M. javanica & $\begin{array}{c}\text { galhas em } \\
\text { tomate }\end{array}$ \\
\hline 0 & 60 & 99 & 29 \\
25 & 49 & 99 & 13 \\
50 & 56 & 97 & 24 \\
100 & 57 & 97 & 39 \\
250 & 54 & 97 & 26 \\
\hline
\end{tabular}


A mobilidade das larvas de $H$. glycines e $M$ javanica e a capacidade infectiva das larvas de $M$. javanica, estimada pelo número de galhas produzidas em plantas de tomate, não foram alteradas pela incubação na presença de BTH nas doses utilizadas. Os valores de $F$ das análises de regressão não foram significativos (Tabela $\mathrm{X}$ do Anexo).

5.9 Efeito de BTH no acúmulo de fitoalexinas em cotilédones de soja.

A Tabela 26 apresenta a absorbância dos extratos de fitoalexinas no ensaio in vitro com cotilédones de soja. Não houve diferença significativa entre as médias, segundo o teste $F(p<0,05)$.

Tabela 26

Concentração de fitoalexinas em extratos de cotilédones de soja.

\begin{tabular}{cc}
\hline Tratamento & Leitura média a $\mathbf{2 8 5} \mathbf{n m}$ \\
\hline Água & $0,161 \mathrm{a}$ \\
BTH $25 \mathrm{mg} / \mathrm{L}$ & $0,206 \mathrm{a}$ \\
BTH $250 \mathrm{mg} / \mathrm{L}$ & $0,200 \mathrm{a}$ \\
Saccharomyces cerevisae & $0,725 \mathrm{a}$ \\
\hline
\end{tabular}




\subsection{Efeito de BTH no acúmulo de compostos fenólicos em tecidos de soja na ausência de microrganismos}

A extração de compostos fenólicos de folhas e raízes de soja foi feita a partir das plantas obtidas nos três ensaios em casa de vegetação que não envolveram inoculação de microssimbiontes ou patógenos. A Tabela 27 apresenta as médias de medidas de absorbância de extratos de compostos fenólicos para plantas tratadas com $250 \mathrm{mg} / \mathrm{L}$ de BTH e a Tabela 28 , dos ensaios em que BTH foi aplicado na concentração de $25 \mathrm{mg} / \mathrm{L}$.

O tratamento com $250 \mathrm{mg} / \mathrm{L}$ de BTH teve efeito nos extratos de folha, mas não nos de raiz, segundo teste $F$ ao nível de $5 \%$ de significância. As plantas tratadas via foliar com esta concentração apresentaram menor medida média de absorbância que aquelas tratadas simultaneamente por via foliar e radicular, segundo o teste de Tukey ao nível de $5 \%$ de significância.

No primeiro ensaio, o tratamento com BTH na concentração de 25 $\mathrm{mg} / \mathrm{L}$ teve efeito apenas em extratos de raiz. As raízes das plantas tratadas com BTH via radicular apresentaram maior concentração de compostos fenólicos que as do controle, conforme mostrou o teste de Tukey ao nível de 5\% de significância.

No segundo ensaio em que o BTH foi utilizado na concentração de 25 $\mathrm{mg} / \mathrm{L}$, apenas em extratos de folha houve efeito do produto na concentração de compostos fenólicos, segundo teste $F$ ao nível de $5 \%$ de significância. Os extratos das plantas tratadas via foliar apresentaram maior média de 
absorbância que os das plantas controle, segundo o teste de Tukey ao nível de $5 \%$ de significância.

Tabela 27

Efeito de BTH no extrato de compostos fenólicos de tecido de plantas de soja tratadas com BTH $250 \mathrm{mg} / \mathrm{L}$.

\begin{tabular}{|c|c|c|c|}
\hline \multirow[b]{2}{*}{ Tratamentos } & \multicolumn{3}{|c|}{ Medidas médias de absorbância } \\
\hline & Folha & Raiz & \\
\hline Controle & $1,572 \quad a b$ & 0,362 & a \\
\hline BTH foliar & 1,324 & 0,492 & a \\
\hline BTH radicular & $1,511 \quad a b$ & 0,383 & a \\
\hline BTH foliar e radicular & $1,642 \quad b$ & 0,423 & a \\
\hline
\end{tabular}

Nota: letras diferentes indicam que as médias são diferentes segundo teste de Tukey ao nível de $5 \%$ de significância.

Tabela 28

Efeito de BTH no extrato de compostos fenólicos de tecido de plantas de soja tratadas com BTH $25 \mathrm{mg} / \mathrm{L}$.

\begin{tabular}{cccccccc}
\hline & \multicolumn{3}{c}{ Primeiro ensaio } & \multicolumn{2}{c}{ Segundo ensaio } \\
\cline { 2 - 7 } Tratamentos & \multicolumn{2}{c}{ Folha } & \multicolumn{2}{c}{ Raiz } & Folha & Raiz \\
\hline Controle & 0,209 & a & 0,558 & $\mathrm{~b}$ & $0,415 \mathrm{~b}$ & $0,674 \mathrm{a}$ \\
BTH foliar & 0,170 & $\mathrm{a}$ & 0,621 & $\mathrm{~b}$ & $0,533 \mathrm{a}$ & $0,638 \mathrm{a}$ \\
BTH radicular & 0,220 & $\mathrm{a}$ & 1,133 & $\mathrm{a}$ & $0,456 \mathrm{ab}$ & $0,609 \mathrm{a}$ \\
BTH foliar e radicular & 0,174 & $\mathrm{a}$ & 0,732 & $\mathrm{ab}$ & $0,463 \mathrm{ab}$ & $0,572 \mathrm{a}$ \\
\hline
\end{tabular}

Nota: letras diferentes indicam que as médias são diferentes segundo teste de Tukey ao nivel de $5 \%$ de significância. 
As plantas não inoculadas do experimento que testou uma única aplicação de BTH na presença ou ausência de $H$. glycines foram utilizadas para a extração de compostos fenólicos de folha e raiz. As médias de absorbância estão apresentadas na Tabela 29. A aplicação de BTH teve efeito sobre as medidas de absorbância em extratos de raiz, mas não nos de folha. A aplicação de BTH aumentou a absorbância dos extratos de raiz, segundo o teste de Tukey ao nível de $5 \%$ de significância.

Tabela 29

Efeito de BTH no extrato de compostos fenólicos de tecido de plantas de soja tratadas com concentrações crescentes de BTH.

\begin{tabular}{ccc}
\hline Concentração de BTH (mg/L) & Folhas & Raiz \\
\hline 0 & $1,041 \mathrm{a}$ & $0,842 \mathrm{~b}$ \\
25 & $0,975 \mathrm{a}$ & $1,105 \mathrm{ab}$ \\
125 & $0.875 \mathrm{a}$ & $1,200 \mathrm{a}$ \\
250 & $0,829 \mathrm{a}$ & $0,895 \mathrm{ab}$
\end{tabular}

Nota: letras diferentes indicam que as médias são diferentes segundo teste de Tukey ao nivel de $5 \%$ de significância.

\subsection{Efeito de BTH e da colonização por microssimbiontes mutualísticos} no acúmulo de compostos fenólicos em tecidos de soja

As médias de medidas de absorbância dos extratos de folha e raiz, obtidas no ensaio que testou o efeito da interação entre a presença de $G$. intraradices e B. japonicum e a aplicação de BTH na concentração de $25 \mathrm{mg} / \mathrm{L}$, 
estão apresentadas, respectivamente, nas Tabelas 30 e 31. A inoculação com microssimbiontes teve efeito no acúmulo de compostos fenólicos em tecidos de soja, mas não houve efeito de BTH, segundo os testes $F$ ao nível de $5 \%$ de significância. Os resultados apresentados na Tabela 30 mostram que a inoculação de $G$. intraradices reduziu a absorbância nos extratos de folhas e a Tabela 31 mostra que a inoculação de $B$. japonicum aumentou a absorbância a $285 \mathrm{~nm}$ nos extratos de raízes.

Tabela 30

Médias das medidas de absorbância dos extratos de fitoalexinas de folhas no ensaio com microssimbiontes, segundo o tratamento

Presença ou ausência e espécie de microrganismo

Tratamento Sem inoculação G. intraradices B. japonicum Média geral

\begin{tabular}{llllll}
\hline Controle & 0,064 & 0,916 & 0,939 & 0,907 & a \\
Semente & 0,958 & 0,856 & 0,920 & 0,912 a \\
BTH radicular, 4d & 0,875 & 0,780 & 0,903 & 0,853 a \\
BTH foliar, 18 d & 0,921 & 0,772 & 0,871 & 0,855 a \\
BTH radicular, 18 d & 0,839 & 0,766 & 0,874 & 0,826 a \\
\hline
\end{tabular}

\begin{tabular}{llllll}
\hline Média geral & 0,891 & $a$ & 0,818 & b & 0,901
\end{tabular}

Nota: letras diferentes indicam que as médias são diferentes segundo teste de Tukey ao nivel de $5 \%$ de significância. 
Tabela 31

Médias das medidas de absorbância dos extratos de fitoalexinas de raiz no quarto ensaio, segundo o tratamento

\begin{tabular}{|c|c|c|c|c|}
\hline \multirow[b]{2}{*}{ Tratamento } & \multicolumn{4}{|c|}{ Presença ou ausência e espécie de microrganismo } \\
\hline & Sem inoculação & G. intraradices & B. japonicum & Média ger \\
\hline Controle & 0,610 & 0,706 & 1,305 & 0,873 \\
\hline Semente & 0,610 & 0,663 & 1,491 & 0.921 \\
\hline BTH radicular, $4 \mathrm{~d}$ & 0,673 & 0,771 & 1,035 & 0,826 \\
\hline BTH foliar, $18 \mathrm{~d}$ & 0,836 & 0,782 & 1,335 & 0,985 \\
\hline BTH radicular, $18 d$ & 0,852 & 0,645 & 1,315 & 0,937 \\
\hline
\end{tabular}

Nota: letras diferentes indicam que as médias são diferentes segundo teste de Tukey ao nível de $5 \%$ de significância.

5.12 Influência de BTH no padrão eletroforético de isoenzimas presentes em tecidos de soja

a) Peroxidases de raiz

A atividade de peroxidase foi observada em géis PAGE alcalinos após incubação com benzidina, o-dianizidina ou guaiacol.

No gel incubado na presença de benzidina apenas uma banda foi revelada, de mobilidade relativa 0,69 . Sua intensidade foi menor nos extratos das plantas não tratadas com BTH ou tratadas por via foliar, em comparação com plantas tratadas via radicular, com ou sem aplicação simultânea via foliar. 
Este resultado foi obtido em quatro plantas de cada tratamento do primeiro ensaio, no qual foi feita aplicação de BTH $25 \mathrm{mg} / \mathrm{L}$.

Nos géis em que foi utilizada a o-dianizidina como substrato (Figura 10), nas canaletas em que se aplicaram extratos de plantas tratadas por via radicular, tratadas ou não simultaneamente por via foliar, a banda 8 foi mais intensa e quatro outras bandas de maior mobilidade, não presentes nas plantas não tratadas ou tratadas apenas por via foliar, foram reveladas. Este resultado foi verificado em quatro plantas por tratamento do primeiro ensaio com BTH $25 \mathrm{mg} / \mathrm{L}$.

A Figura 11 apresenta um gel revelado em solução de $0,5 \mathrm{M}$ de guaiacol. A utilização deste substrato permitiu a visualização de uma banda mais intensa e quatro bandas adicionais nas canaletas que receberam BTH via radicular, com ou sem aplicação concomitante via foliar, em relação as plantas controle ou tratadas apenas por via foliar, da mesma forma que a o-dianizidina. As três bandas de maior mobilidade foram observadas quando utilizada a concentração $0,5 \mathrm{M}$ do guaiacol, e não com a concentração $0,05 \mathrm{M}$. As bandas diferenciais foram observadas em três plantas de cada tratamento do primeiro ensaio e quatro plantas de cada tratamento do segundo ensaio.

\section{b) Polifenoloxidases de raiz}

Os extratos de proteína de raiz das plantas não tratadas com BTH apresentaram três bandas nos géis alcalinos revelados em catecol (Figura 12). O mesmo padrão foi observado para plantas tratadas com BTH apenas por via 
foliar. Nos tratamentos em que foi feita aplicação radicular de BTH, com ou sem aplicação simultânea via foliar, a banda 3 foi mais intensa e quatro outras bandas foram reveladas. Este padrão foi verificado em quatro plantas por tratamento do primeiro ensaio, no qual foi feita aplicação de BTH $25 \mathrm{mg} / \mathrm{L}$.

\section{c) Quitinases de raiz}

Os perfis eletroforéticos em géis alcalinos de proteínas de raiz de soja que apresentaram atividade de quitinases foram os mesmos para extratos de plantas não tratadas por BTH ou tratadas por via radicular ou foliar, sendo observadas sempre seis isoformas (Figura 13).

\section{d) Superóxido dismutases de raízes}

Extratos de raiz de plantas tratadas ou não tratadas com BTH, em géis PAGE alcalinos, revelados para visualização de superóxido dismutases, apresentaram os mesmos perfis eletroforéticos (Figura 14).

\section{e) Peroxidases de folhas}

Extratos de proteínas de folhas de soja, quando submetidos a eletroforese em géis alcalinos e revelados na presença o-dianizidina, apresentaram de quatro a seis bandas, no entanto, sem haver repetibilidade dos padrões eletroforéticos entre diferentes plantas de um mesmo tratamento. 
Quando utilizado o substrato guaiacol, não apareceram bandas no caso de géis alcalinos. Em géis ácidos, a utilização deste substrato permitiu visualização de bandas, mas não houve repetibilidade entre plantas dos mesmos tratamentos. O mesmo ocorreu em géis ácidos, quando utilizado o substrato benzidina.

\section{f) Polifenoloxidases de folhas}

Não houve repetibilidade entre extratos de proteínas de folha de plantas que receberam o mesmo tratamento com BTH em géis alcalinos para comparação de isoformas ácidas de polifenoloxidase, utilizando catecol para a revelação.

\section{g) Quitinases de folhas}

A atividade de quitinase foi observada em géis alcalinos que receberam extratos de proteínas de folha. Não se verificaram diferenças de padrão entre extratos que receberam diferentes tratamentos com BTH (Figura 15).

\section{h) Superóxido dismutases de folhas}

Obtiveram-se géis alcalinos de poliacrilamida $12 \%$ aplicados com proteínas de folha, mostrando atividade de superóxido dismutase com definição parcial (Figura 14). Freqüentemente apresentaram coalescência de bandas. Sempre que definidas, as bandas mostravam o mesmo padrão para plantas com os diferentes tratamentos de BTH. 
$\begin{array}{llllllllllll}C & S & S & R & R & C & F & F\end{array}$

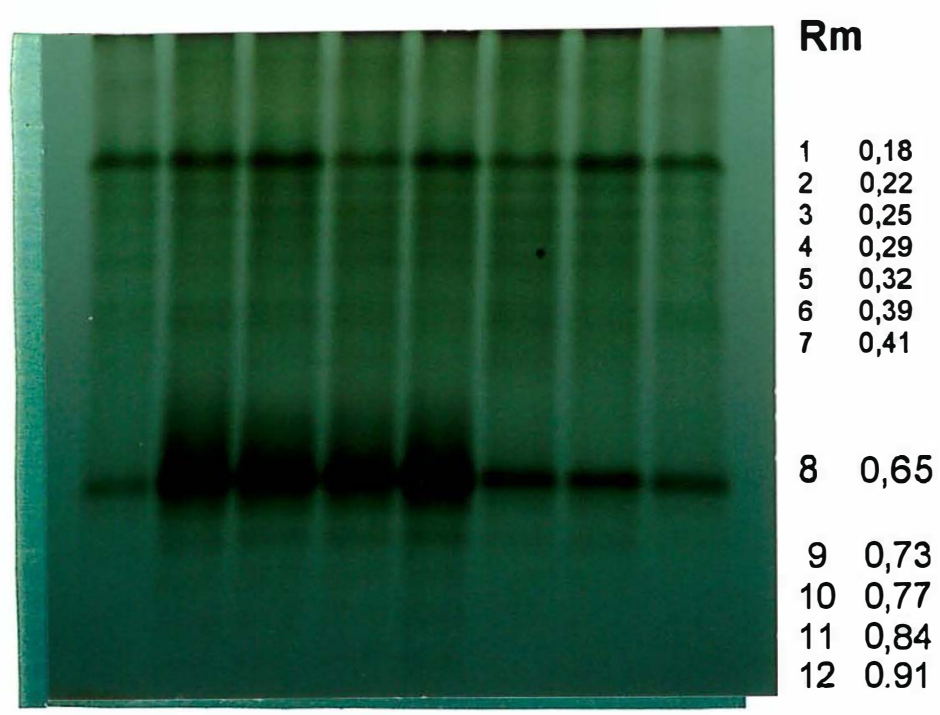

Figura 10: Proteínas de raízes de soja em gel de poliacrilamida $10 \%$ revelado na presença de o-dianizidina. Cada canaleta recebeu extrato de uma planta, portanto, observam-se extratos de duas plantas por tratamento. $\mathbf{C}=$ controle; $\mathbf{F}=$ aplicação de BTH via foliar; $\mathbf{R}=$ aplicação de $\mathrm{BTH}$ via raiz; $\mathbf{S}=$ aplicação simultânea na raiz e nas folhas.

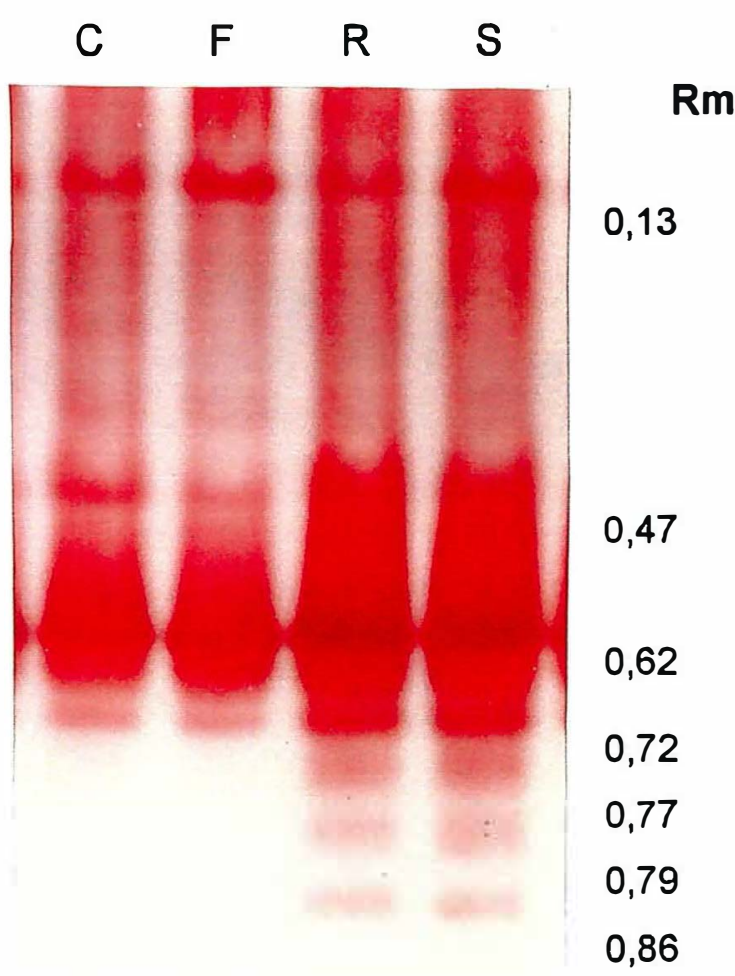

Figura 11: Proteínas de raízes de soja em gel de poliacrilamida 10\%, revelado na presença de guaiacol. Cada canaleta recebeu extrato de uma planta. $\mathbf{C}=$ controle; $\mathbf{F}=$ aplicação de BTH via foliar; $\mathbf{R}=$ aplicação de BTH via raiz; $\mathbf{S}=$ aplicação simultânea na raiz e nas folhas. 


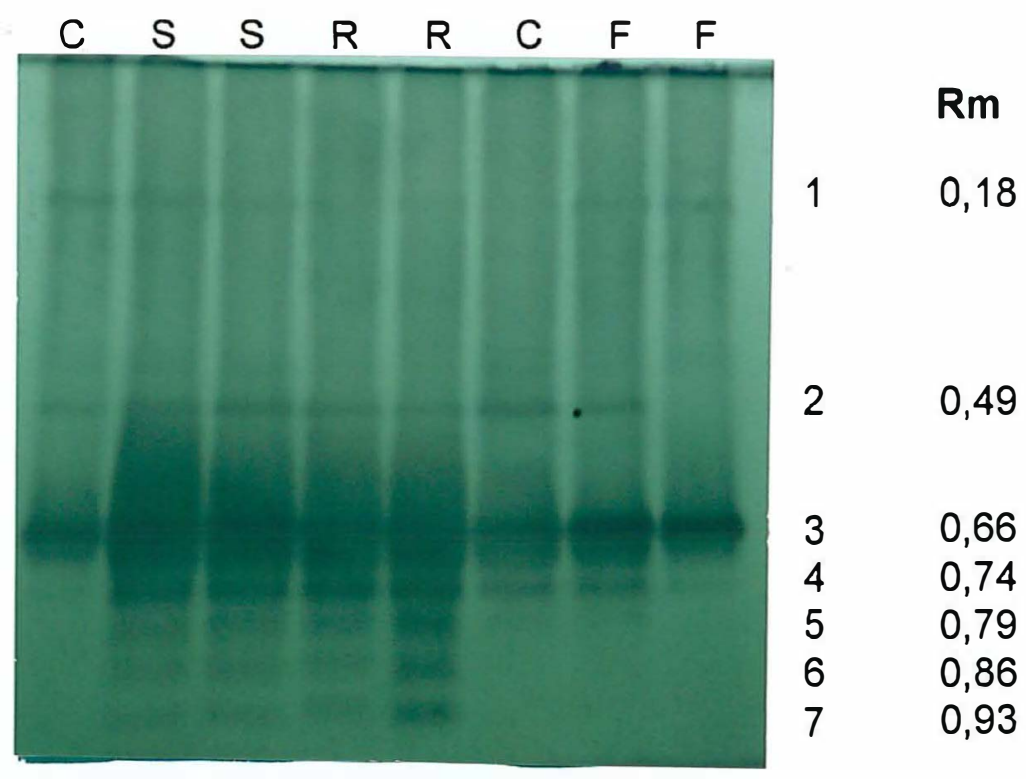

Figura 12: Proteínas de raízes de soja em gel alcalino de poliacrilamida $7 \%$, revelado na presença de catecol. Cada canaleta recebeu extrato de uma planta, portanto, observam-se extratos de duas plantas por tratamento. $\mathbf{C}=$ controle; $\mathbf{F}=$ aplicação de BTH via foliar; $\mathbf{R}=$ aplicação de $\mathrm{BTH}$ via raiz; $\mathbf{S}=$ aplicação simultânea na raiz e nas folhas.

\section{$\begin{array}{lllllllllllllllll}C & F & R & S & C & F & R & S\end{array}$}

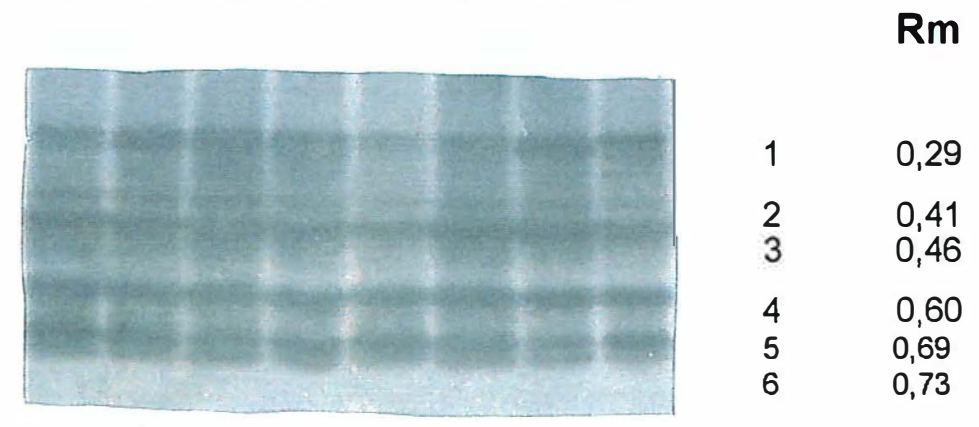

Figura 13: Quitinase em raízes de plantas de soja, em gel de poliacrilamida $15 \%$. Cada canaleta recebeu extrato de uma planta, portanto, observam-se extratos de duas plantas por tratamento. $\mathbf{C}=$ controle; $\mathbf{F}=$ aplicação de $\mathrm{BTH}$ via foliar; $\mathbf{R}=$ aplicação de BTH via raiz; $\mathbf{S}$ = aplicação simultânea na raiz e nas folhas. 
$S \quad C \quad F \quad R$

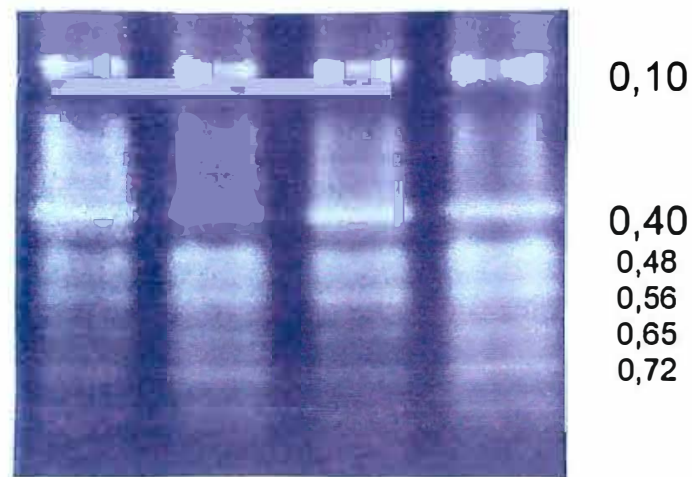

Figura 14: Superóxido dismutase em raízes de plantas de soja, em gel de poliacrilamida $15 \%$. Cada canaleta recebeu extrato de uma planta. $\mathbf{C}=$ controle; $\mathbf{F}=$ aplicação de $B T H$ via foliar; $\mathbf{R}=$ aplicação de $B T H$ via raiz; $\mathbf{S}=$ aplicação simultânea na raiz e nas folhas. 


\section{C $\quad F \quad R \quad S$}

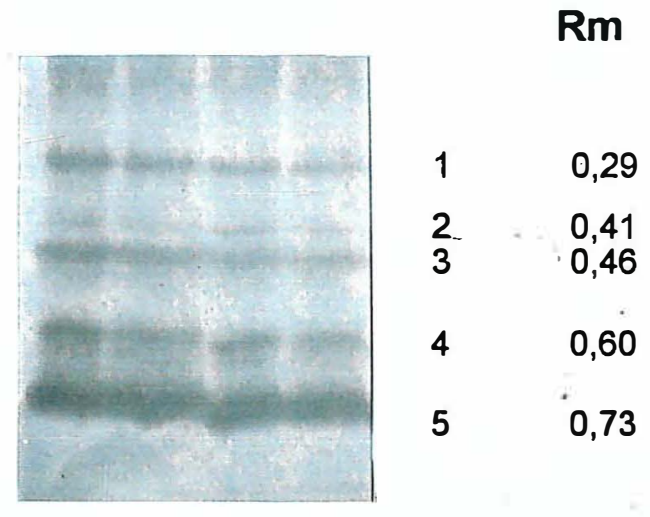

Figura 15: Indução de quitinase em folhas de plantas de soja, em gel de poliacrilamida $15 \%$. Cada canaleta recebeu extrato de uma planta, portanto, observam-se extratos de duas plantas por tratamento. $\mathbf{C}=$ controle; $\mathbf{F}=$ aplicação de BTH via foliar; $\mathbf{R}=$ aplicação de BTH via raiz; $\mathbf{S}=$ aplicação simultânea na raiz e nas folhas.

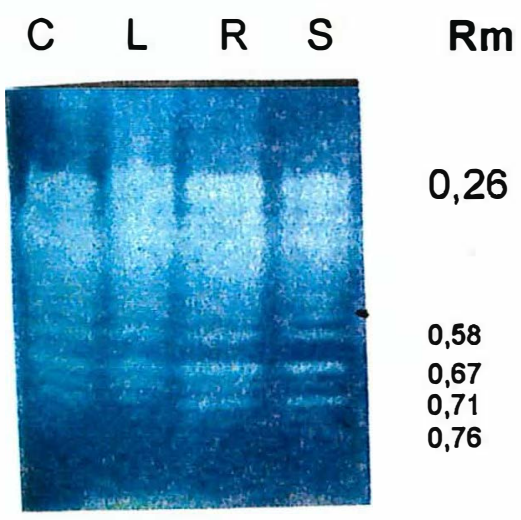

Figura 16: Superóxido dismutase em folhas de soja, em gel de poliacrilamida $12 \%$. Cada canaleta recebeu extrato de uma planta, portanto, observam-se extratos de duas plantas por tratamento. $\mathbf{C}=$ controle; $\mathbf{F}=$ aplicação de $\mathrm{BTH}$ via foliar; $\mathbf{R}=$ aplicação de $\mathrm{BTH}$ via raiz; $\mathbf{S}$ = aplicação simultânea na raiz e nas folhas. 


\section{DISCUSSÃO}

a) Efeito de BTH no desenvolvimento vegetativo da soja

O efeito direto de BTH sobre soja, isto é, na ausência de interação da planta com microssimbiontes ou patógenos, pode ser avaliado não só nos três ensaios que não utilizaram inoculação, como nas plantas não inoculadas do experimento com microssimbiontes e dos dois ensaios com nematóides.

Em dois ensaios que testaram o modo de aplicação de BTH na concentração $25 \mathrm{mg} / \mathrm{L}$, repetiram-se os mesmos tratamentos, inclusive época e cuidados com aplicação do produto. Ainda, mantiveram-se iguais o intervalo de variação de temperatura e as condições físicas do solo. A adubação foi modificada do primeiro para o segundo experimento porque, no primeiro, as plantas além de terem desenvolvimento vegetativo relativamente baixo, apresentaram as folhas primárias com senescência precoce, o que pode ser atribuído à deficiência nutricional. Provavelmente foi a alteração de adubação que refletiu no desenvolvimento vegetativo das plantas, maior no segundo que 
no primeiro ensaio, como também no efeito de BTH sobre o desenvolvimento vegetativo. No ensaio em que as plantas apresentaram menor desenvolvimento, foram estimuladas pela aplicação radicular de BTH, enquanto que o mesmo tratamento reduziu o desenvolvimento no ensaio com maior nível de adubação.

A aplicação radicular de BTH, em plantas de soja não inoculadas, provocou, de maneira consistente em três diferentes ensaios, redução de desenvolvimento vegetativo e encarquilhamento foliar. Enquanto que no ensaio em que foi feita uma única aplicação, o sintoma de encarquilhamento reduziuse com o desenvolvimento das plantas, no ensaio em que as aplicações foram a cada sete dias o sintoma intensificou-se com o tempo, provocando inclusive forte redução de área foliar e de crescimento, bem como brotação a partir do nó cotiledonar. Em conjunto, os resultados mostraram que BTH é fitotóxico em soja quando aplicado por via radicular. Não se exclui a possibilidade de que este efeito possa ser superado pelo desenvolvimento das plantas no final do ciclo da cultura, no caso de uma única aplicação no início do ciclo, como mostrou o experimento com uma única aplicação de BTH, em concentrações de 25, 125 e250mg/L.

A aplicação foliar do produto nas concentrações de 25 e $250 \mathrm{mg} / \mathrm{L}$ não provocou alterações morfológicas das folhas ou redução de desenvolvimento das plantas, em nenhum dos experimentos, mostrando que até a dose testada de $250 \mathrm{mg} / \mathrm{L}$ não existe fitotoxicidade do produto nesta forma de aplicação. Trabalhando com BTH em aplicação foliar em soja, nas doses de 35 e 375 
$\mathrm{mg} / \mathrm{L}$, Dann et al. (1998) não relataram sinais de fitotoxicidade. Segundo Friedrich et al. (1996), AS e INA têm efeito fitotóxico em algumas espécies, mas isto ainda não havia sido demonstrado no caso de BTH. Em feijoeiro, a aplicação foliar de BTH em concentrações a partir de $84 \mathrm{mg} / \mathrm{L}$ provocou deformações e redução de tamanho de folhas (Siegrist et al., 1997).

Os três indutores de SAR conhecidos, ácido salicilico, INA e BTH, apresentam efeitos fitotóxicos, dependendo da espécie de planta e dose dos produtos utilizada. A resistência sistêmica adquirida é um processo de alterações fisiológicas, onde as células vegetais produzem compostos que têm a finalidade de restringir a colonização por patógenos. Alguns destes compostos podem tornar-se tóxicos inclusive à células vegetais, como, por exemplo, o peróxido de hidrogênio e fitoalexinas. Assim, é possivel que a propriedade dos compostos de ativar SAR seja indissociável de propriedades fitotóxicas. A fitotoxidez causada por BTH em soja, neste trabalho, e a concentração de fitoalexinas em cotilédones de sorgo (Osswald et al., 1998) aumentam com a concentração do produto aplicada. Estas observações não invalidam a viabilidade de uso agrícola dos produtos, desde que feito manejo adequado da aplicação. 


\section{b) Efeito de BTH no padrão eletroforético de isoenzimas e fitoalexinas de soja}

A análise do perfil eletroforético de isoenzimas em extratos de raiz, de peroxidases reveladas em o-dianizidina ou guaiacol, mostrou que as plantas que receberam $\mathrm{BTH}$, via raiz, mostraram aumento de atividade de uma isoforma e indução de três novas isoformas. O mesmo ocorreu em géis revelados para polifenoloxidase. A mobilidade relativa da isoforma de atividade diferencial foi consistente para todos os três sistemas de revelação, sugerindo que uma mesma enzima provoca o aparecimento de banda. As informações na literatura de que catecol também é substrato de peroxidase (Macko et al., 1967) e que benzidina (van Loon, 1970) e guaiacol (Rudolph \& Stahmann, 1964) são substratos recomendados para distinguir peroxidases de outras enzimas, permitiram considerar que as bandas observadas são provavelmente peroxidases. A atividade de peroxidase em uma enzima com substrato inespecífico é consistente com as propriedades da enzima peroxidase classificada como EC 1.11.1.7.

O perfil obtido, utilizando-se guaiacol como substrato, repetiu-se utilizando-se plantas de dois diferentes ensaios em casa de vegetação, mostrando a repetibilidade do padrão obtido.

Peroxidases ácidas são enzimas de parede celular (Ward et al., 1991) e são capazes de produzir peróxido de hidrogênio. Este tem função direta na defesa de plantas contra patógenos, pois difunde-se através da membrana 
celular e pode ser tóxico aos microrganismos, além de ter função indireta, servindo à célula vegetal como um mensageiro intermediário na sinalização de indução de resposta de resistência (Hammond-Kosack \& Jones, 1996).

A utilização de guaiacol $0,5 \mathrm{M}$ ao invés de $0,05 \mathrm{M}$ para a incubação do gel foi útil porque permitiu visualização de três novas bandas, já visualizadas no gel revelado por o-dianizidina, e mostrou que estas isoformas eram provavelmente peroxidases, uma vez que este substrato é considerado específico para esta enzima (Rudolph \& Stahmann, 1964). Estas bandas não foram observadas no gel incubado com benzidina e, provavelmente, pudessem ter sido observadas com utilização de maior concentração deste substrato.

Não foi encontrada diferença de perfil eletroforético de quitinases ácidas entre plantas não tratadas ou tratadas por via foliar ou radicular em extratos de proteínas de folha ou de raiz. Siegrist et al. (1997) mostraram que em feijoeiro plantas tratadas via foliar apresentaram, em extrato de folha, aumento de atividade total de quitinases. Em tabaco a aplicação de BTH induziu atividade de quitinases ácidas e básicas (Friederich et al., 1996). Possivelmente um menor intervalo entre a aplicação do produto e a colheita das plantas possibilitasse observação de diferentes perfis, ou existisse diferença se tivessem sido observadas as isoformas básicas.

Não foi encontrada repetibilidade de perfil eletroforético entre plantas que receberam o mesmo tratamento com BTH em extratos de folha revelados por o-dianizidina, benzidina, catecol ou guaiacol. Isto pode ter sido causado pelo fato de ter sido colhida a parte aérea como um todo, e um novo 
experimento em que se extraíssem proteínas, por exemplo, do segundo par de folha, talvez possibilitasse repetibilidade.

As isoformas diferenciais de peroxidases podem servir como marcadores bioquímicos do efeito da aplicação de BTH em raízes de soja. Estas foram encontradas nas plantas de soja, 17 dias após a aplicação de BTH. Isto pode indicar que, pelo menos durante este período, o efeito do produto, mediado pela ação de peroxidases está ativado, não sendo necessária uma nova aplicação. Embora a aplicação de BTH tenha tido efeito duradouro na proteção de arroz e trigo contra doenças fúngicas (Görlach et al., 1996), em soja foram necessárias quatro aplicações com intervalos com cerca de 10 dias para indução de proteção contra Sclerotinia sclerotiorum (Dann et al., 1998).

Fitoalexinas são metabólitos secundários produzidos pelas plantas com atividade antimicrobiana (Fischer \& Hain, 1994). Neste trabalho, a aplicação de BTH em cotilédones de soja não induziu a biossíntese de fitoalexinas. Em mesocótilos de sorgo houve acúmulo de fitoalexinas em resposta ao tratamento com BTH (Osswald et al., 1998).

c) Efeito de BTH na interação da soja com microssimbiontes mutualísticos

Houve redução significativa de colonização por $B$. japonicum e não de colonização pelo fungo micorrízico arbuscular $G$. intraradices. Já foi 
demonstrado que a aplicação de BTH em plantas tem efeito sobre a capacidade de colonização destas por patógenos (Friederich et al., 1996; Görlach et al., 1996; Lawton et al., 1996). É provável que os mesmos mecanismos fisiológicos responsáveis pela inibição da colonização por patógenos sejam responsáveis pela redução de colonização pelos microssimbiontes mutualísticos.

Embora se tenha demonstrado que durante a colonização por rizóbios ocorrem na planta diversas alterações fisiológicas relacionadas à defesa de plantas contra patógenos, entre as quais aumento de atividade de peroxidase e da concentração de fitoalexinas, não é claro se estas alterações da planta são uma tentativa da planta de defender-se do microssimbionte, inibindo o processo de colonização (Spaink, 1995).

A indução de isoformas de peroxidase em raiz de soja, provocada pela aplicação de BTH, pode ser responsável pela inibição de colonização por $B$. japonicum, sugerindo que esta resposta fisiológica durante o processo natural de colonização por rizóbios seja parte da reação de defesa. Staehelin et al. (1992) mostraram que, enquanto que em nódulos de plantas de soja eficientes na fixação de nitrogênio existe alta atividade de peroxidase apenas na região sua cortical, em nódulos produzidos por uma estirpe mutante de $B$. japonicum, onde não ocorre fixação, a atividade de peroxidase foi alta também na região interna dos nódulos, o que provavelmente denota uma tentativa da planta de defender-se da colonização pelo falso microssimbionte.

A não inibição de colonização pelo fungo micorrízico arbuscular em plantas que receberam o mesmo tratamento com BTH que aquelas que 
apresentaram indução de peroxidases em raiz sugerem que a atividade destas enzimas não tenha ação inibitória sobre a colonização pelo endófito ou que a interação deste com a planta seja capaz de inibir a atividade da enzima, mesmo que inicialmente induzida pelo produto químico. David et al. (1998) mostraram que, em tabaco, a aplicação radicular de BTH $50 \mathrm{mg} / \mathrm{L}$ provocou, em raiz, aumento de atividade de uma isoforma de quitinase básica, a mesma cuja atividade é inibida durante a colonização pelo fungo $G$. intraradices. Quando plantas micorrizadas foram tratadas com BTH por via radicular, a atividade da isoforma permaneceu abaixo da dos controles não inoculados e não tratados, mostrando que a interação com o fungo tem capacidade de inibir o efeito do produto.

d) Efeito de BTH sobre nematóides fitopatogênicos na sua interação com soja

BTH mostrou ter efeito na infecção por Meloidogyne javanica e Heterodera glycines. Ambos são patógenos importantes para a cultura da soja (Almeida et al., 1995; Wrather et al., 1997). A utilização de cultivares resistentes tem como limitações a base genética estreita da cultura da soja e a quebra de resistência, observada em diversas áreas de produção (Dong et al., 1997). A maioria dos nematicidas tem utilização proibida, devido à contaminação do meio ambiente e toxidez (Duncan, 1991). Assim, é de grande interesse a descoberta de produtos que tenham efeito no controle de nematóides. 
Não houve efeito direto de BTH sobre as larvas dos nematóides, que são fases infectivas, isto é, responsáveis pela penetração nas raízes. Isto permite inferir que, se o produto tem efeito de dificultar o processo de infecção, isto se dá através de um efeito do produto sobre a planta, capacitando-a a restringir a penetração ou o estabelecimento das larvas. Ainda, não tendo efeito direto sobre larvas, o produto não pode ser usado para controle das populações de nematóides no solo.

Diversos trabalhos na literatura relacionam mecanismos pós formados de resistência de plantas a doenças com proteção de plantas contra nematóides. Por exemplo, em soja (Ibrahim \& Lewis, 1986) e em tomateiro (Ogallo \& McClure, 1996) a pré inoculação com uma espécie de Meloidogyne restringiu a multiplicação de outra espécie do mesmo gênero. Em batata, a infecção pelos nematóides Globodera pallida e Meloidogyne incognita induziu transcrição sistêmica de um gene de catalase, também induzida por ácido acetil salicílico, o que sugere indução de SAR em decorrência da presença dos nematóides, mas não mostra evidência da inibição da infecção pelos nematóides em plantas ativadas. Assim, não é ainda bem estabelecido que a SAR seja efetiva contra nematóides. Os indutores químicos de SAR, como o BTH, criam uma oportunidade de pesquisa para definir este mecanismo de resistência em novas espécies e patógenos. Entretanto, neste trabalho, o efeito fitotóxico de BTH na forma de aplicação e doses do produto que resultaram em redução da intensidade de infecção pelos nematóides não permite inferir que a restrição de densidade de colonização tenha sido via SAR 
A indução de novas isoformas de peroxidase em plantas de soja que receberam aplicação de BTH via radicular, pode estar relacionada com a inibição de infecção por $M$. javanica e $H$. glycines. Zacheo et al. (1993) mostraram que, em tomateiro, existe maior indução de atividade de peroxidases durante infecção por $M$. incognita em plantas que contêm o gene $M i$, que confere resistência. O efeito de peroxidases em gerar peróxido de hidrogênio ou outras respostas celulares mediadas por este sinal podem ter efeito sobre nematóides, da mesma forma que sobre bactérias ou fungos.

e) BTH como indutor de resistência sistêmica adquirida

Segundo Kessmann et al. (1994), um composto pode ser considerado um ativador de SAR se induzir proteção aos mesmos patógenos e ativar os mesmos genes ativados em SAR, sem ter atividade antimicrobiana por si mesmo. A indução de SAR por BTH foi caracterizada em Arabidopsis (Lawton et al., 1996) e tabaco (Friedrich et al., 1996), espécies onde foram previamente estabelecidos o espectro característico de patógenos e marcadores moleculares de SAR. Além disto, em Arabidopisis são conhecidos mutantes, que permitiram demonstrar que a aplicação de BTH restabeleceu propriedades de resistência a doenças em plantas geneticamente transformadas de forma a perder a capacidade de acumular ácido salicílico, o que demonstrou que BTH e AS atuam na mesma via celular de sinalização, além de, com outros mutantes, 
ter sido possível demonstrar que, da mesma forma que SAR, o efeito de BTH é independente de etileno (Lawton et al., 1996).

Indutores bioquímicos de SAR podem consistir em ferramentas auxiliares para caracterização do processo em espécies onde não são bem estabelecidos seu espectro de proteção ou marcadores moleculares ou bioquímicos. Este trabalho pode contribuir para a caracterização do efeito de BTH em soja, onde a indução biótica ou abiótica de resistência pós-formada é pouco estudada. Wrather \& Elrod (1990) mostraram que o aparecimento de lesão em epicótilos com Colletotrichum truncatum foi menor nas plantas que tiveram cotilédones previamente tratados com esporos de $C$. truncatum ou $C$. lagenarium, um patógeno em curcubitáceas. Dann et al. (1998) mostraram que a aplicação de BTH em soja diminuiu a severidade da doença causada por Sclerotinia sclerotiorum em campo, dependendo do ano e localidade estudados.

Não houve ação direta de BTH sobre larvas dos nematóides, o que permitiu inferir que a restrição de infecção por nematóides em raízes de soja foi mediada pela planta, o que seria possível através da indução pelo produto de mecanismos pós-formados de resistência.

Neste trabalho, a aplicação de BTH restringiu a densidade de colonização de raízes de soja por uma bactéria (B. japonicum) e de infecção por dois nematóides ( $M$. javanica e $H$. glycines). Em conjunto com a proteção contra Sclerotinia sclerotiorum, relatada por Dann et al. (1998), demonstrou-se que o BTH em soja provê amplo espectro de proteção, considerado uma característica importante de SAR (Ryals et al., 1996). No entanto, a existência 
de fitotoxidez do produto nas doses em que ele teve efeito sobre as medidas de intensidade de infecção pelos nematóides não nos permite afirmar que a proteção seja efetivada via SAR.

Houve indução de peroxidases ácidas em raízes de soja. Peroxidase é considerado um marcador de SAR (Strobel et al., 1996; Zhang et al., 1996) e a indução de novas isoformas de peroxidase é consistente com a afirmativa de que BTH induz SAR também em soja.

\section{f) Modo de aplicação e translocação de sinal}

Nas plantas que receberam aplicação de BTH, na concentração de $25 \mathrm{mg} / \mathrm{L}$ apenas via foliar, não houve nos géis PAGE indução de novas isoformas ou aumento de intensidade de bandas, para qualquer sistema de revelação utilizado. Além disso não houve redução do número ou peso de matéria seca de nódulos por planta, em decorrência da aplicação de BTH, utilizado na mesma concentração, em relação ao tratamento controle. Também não houve efeito fitotóxico da aplicação foliar de BTH $250 \mathrm{mg} / \mathrm{L}$, como houve no caso da aplicação radicular. Em conjunto, os resultados mostram que BTH tem maior eficiência quando aplicado via radicular ou que as diferenças observadas entre plantas que receberam o produto via foliar ou via radicular devam-se a não translocação de sinal da parte aérea para a raiz. 
Isto sugere, também, que a aplicação foliar do produto em concentrações similares às utilizadas, isto é, até $250 \mathrm{mg} / \mathrm{L}$, não tenha efeito de restrição de infecção pelos nematóides $H$. glycines e $M$. javanica.

Siegrist et al. (1997) mostraram que o tratamento de sementes com BTH induziu resistência em feijoeiro a Uromyces appendiculatus, Colletotricum lindemuthianum e Xanthomonas campestris pv. phaseoli. Mostraram também que o tratamento de sementes com BTH ou INA reduziu tombamento de plântulas em solo infestado com Rhizoctonia solani, diferentemente de trabalho de pesquisa anterior, onde o tratamento químico foi feito em plântulas e não houve proteção. Isto mostrou que o modo de aplicação do produto foi importante para que houvesse manifestação de resistência, o que repete de maneira mais adequada a realidade agrícola, uma vez que o microrganismo tem persistência no solo. Este também é o caso dos microssimbiontes e nematóides estudados no presente trabalho. Além disto, a aplicação em semente tem custo menor e tem maior viabilidade econômica para recomendação para a cultura da soja. Neste trabalho, em discussão, esse tratamento não teve efeito sobre as medidas de desenvolvimento vegetativo, mas tendeu a reduzir a intensidade de colonização por $B$. japonicum, embora não diferindo significativamente do controle. 


\section{g) Comentários finais}

Em soja, a aplicação foliar de BTH não teve efeito sobre 0 desenvolvimento das plantas ou morfologia da folha em concentração de $25 \mathrm{~g} / \mathrm{L}$ ou $250 \mathrm{~g} / \mathrm{L}$. Também não teve efeito sobre $B$. japonicum ou $G$. intraradices na concentração de $25 \mathrm{mg} / \mathrm{L}$. Assim, não há indícios de restrição a aplicação, em parte aérea, de BTH nestas doses para a cultura da soja. Ao contrário, o produto não é indicado para aplicação radicular, pois apresentou sinais de fitotoxicidade inclusive com aplicação única na concentração de $25 \mathrm{mg} / \mathrm{L}$, além de ter restringido a colonização por $B$. japonicum.

As plantas de soja responderam à aplicação radicular de BTH com uma alteração fisiológica que diminui a intensidade de infecção pelos nematóides fitopatogênicos, nas condições deste trabalho. Não é possível afirmar se este efeito pode ser dissociado da fitotoxidez do produto.

Uma questão subjacente à utilidade de ativadores de defesa vegetal no combate aos patógenos em culturas comerciais é se é significativa a ativação de mecanismos pós-formados de defesa, como a resistência sistêmica adquirida, ao nível de campo, uma vez que, nestas condições, as plantas estão em contato com microssimbiontes e patógenos que podem estar constantemente ativando tais mecanismos de defesa. A travessia da casa de vegetação ao campo deve ocorrer com a liberação comercial de ativadores de defesa vegetal como o BTH. Marcadores bioquímicos podem vir a ser ferramentas importantes na resposta à questão da freqüência e intensidade 
com que esse estímulo biótico é suficiente para ativar os mecanismos de defesa, e em que medida os indutores abióticos os auxiliam. 


\section{CONCLUSÕES}

- Em raiz de soja existe aumento de atividade de uma isoforma de peroxidase ácida e indução de quatro novas isoformas em decorrência da aplicação de BTH via radicular, que podem ser utilizadas como marcadores bioquímicos do efeito do produto.

- A aplicação radicular de BTH tem efeito fitotóxico em soja.

- A aplicação radicular de BTH pode reduzir a intensidade de colonização de raízes de soja por Bradyrhizobium japonicum,

- A aplicação radicular de BTH pode reduzir o nível de infecção de raízes de soja por Meloidogyne javanica e Heterodera glycines.

- O efeito em raiz da aplicação foliar de BTH não existe ou é menos intenso do que a aplicação radicular. 
ANEXO 


\section{Tabela I}

Efeito do BTH $250 \mathrm{mg} / \mathrm{L}$ no desenvolvimento vegetativo da soja : Análises de variância, coeficientes de variação (CV) e médias gerais das variáveis peso de matéria fresca da parte aérea (FA), peso de matéria seca da parte aérea (SA), peso de matéria fresca da raiz (FR) e peso de matéria seca da raiz (SR).

\begin{tabular}{|c|c|c|c|c|c|}
\hline Variável & Causa de Variação & $\overline{G L}$ & QM & $\bar{F}$ & $p$-valor \\
\hline & Tratamento & 3 & 256,16 & 4,97 & 0,0181 \\
\hline \multirow[t]{4}{*}{ FA } & Resíduo & 12 & 51,57 & & \\
\hline & Média $=24,23$ & & & & \\
\hline & $C V(\%)=29,64$ & & & & \\
\hline & Tratamento & 3 & 16,82 & 5,28 & 0,0149 \\
\hline \multirow[t]{4}{*}{ SA } & Resíduo & 12 & 3,19 & & \\
\hline & Média & 5,18 & & & \\
\hline & CV $(\%)$ & 34,31 & & & \\
\hline & Tratamento & 3 & 93,64 & 2,14 & 0,1485 \\
\hline \multirow[t]{4}{*}{ FR } & Resíduo & 12 & 43,76 & & \\
\hline & Média $=17,10$ & & & & \\
\hline & $C V(\%)=38,69$ & & & & \\
\hline & Tratamento & 3 & 1,86 & 1,51 & 0,2627 \\
\hline \multirow[t]{3}{*}{ SR } & Resíduo & 12,00 & 1,23 & & \\
\hline & Média $=2,57$ & & & & \\
\hline & $C V(\%)=43,11$ & & & & \\
\hline
\end{tabular}




\section{Tabela II}

Efeito do BTH $25 \mathrm{mg} / \mathrm{L}$ no desenvolvimento vegetativo da soja no primeiro experimento: Análises de variância, coeficientes de variação (CV\%) e médias gerais das variáveis peso de matéria fresca da parte aérea (FA), peso de matéria seca da parte aérea (SA), peso de matéria fresca da raiz (FR) e peso de matéria seca da raiz (SR).

\begin{tabular}{|c|c|c|c|c|c|}
\hline Variável & Causa de Variação & $\overline{G L}$ & $\overline{Q M}$ & $\bar{F}$ & p-valor \\
\hline & Tratamento & 3 & 12,57 & 3,12 & 0,0419 \\
\hline \multirow[t]{4}{*}{ FA } & Resíduo & 28 & 4,03 & & \\
\hline & Média $=7,19$ & & & & \\
\hline & $\mathrm{CV}(\%)=27,92$ & & & & \\
\hline & Tratamento & 3 & 1,16 & 3,64 & 0,0247 \\
\hline \multirow[t]{4}{*}{ SA } & Resíduo & 28 & 0,32 & & \\
\hline & Média $=1,66$ & & & & \\
\hline & $C V(\%)=33,91$ & & & & \\
\hline & Tratamento & 3 & 2,74 & 1,05 & 0,3856 \\
\hline \multirow[t]{4}{*}{ FR } & Resíduo & 28 & 2,61 & & \\
\hline & Média $=6,11$ & & & & \\
\hline & $\mathrm{CV}(\%)=26,41$ & & & & \\
\hline & Tratamento & 3 & 0,12 & 1,10 & 0,3671 \\
\hline \multirow[t]{3}{*}{ SR } & Resíduo & 26,00 & 0,1059 & & \\
\hline & Média $=0,63$ & & & & \\
\hline & $\mathrm{CV}(\%)=51,84$ & & & & \\
\hline
\end{tabular}




\section{Tabela III}

Efeito do BTH $25 \mathrm{mg} / \mathrm{L}$ no desenvolvimento vegetativo da soja no segundo experimento: Análises de variância, coeficientes de variação (CV\%) e médias gerais das variáveis peso de matéria fresca da parte aérea (FA) e peso de matéria fresca da raiz (SR).

\begin{tabular}{|c|c|c|c|c|c|}
\hline Variável & Causa de Variação & $\overline{G L}$ & QM & $\bar{F}$ & $p$-valor \\
\hline & Tratamento & 3 & 19,24 & 1,14 & 0,3447 \\
\hline \multirow[t]{4}{*}{ FA } & Resíduo & 36 & 16,8315 & & \\
\hline & Média $=14,64$ & & & & \\
\hline & $C V(\%)=28,02$ & & & & \\
\hline & Tratamento & 3 & 25,87 & 4,37 & 0,0101 \\
\hline \multirow[t]{3}{*}{ FR } & Resíduo & 36 & 5,9199 & & \\
\hline & Média $=7,36$ & & & & \\
\hline & $C V(\%)=33,07$ & & & & \\
\hline
\end{tabular}


Tabela IV

Influência dos microssimbiontes $B$. japonicum e $G$. intraradices no desenvolvimento vegetativo da soja: Análises de variância, coeficientes de variação (CV\%) e médias gerais das variáveis peso de matéria fresca da parte aérea (FA), peso de matéria seca da parte aérea (SA), peso de matéria fresca da raiz (FR) e peso de matéria seca da raiz (SR).

\begin{tabular}{|c|c|c|c|c|c|}
\hline Variável & Causas de Variação & $\overline{G L}$ & QM & $\bar{F}$ & $p$-valor \\
\hline & Microrganismo & 2 & 1225,78 & 42,12 & $5,4 \mathrm{E}-13$ \\
\hline & Concentração de BTH & 4 & 87,65 & 3,01 & 0,0232 \\
\hline \multirow[t]{6}{*}{ FA } & Microrganismo $\times \mathrm{BTH}$ & 8,00 & 41,26 & 1,42 & 0,2030 \\
\hline & Resíduo & 75 & 29,10 & & \\
\hline & Média $=19,88$ & & & & \\
\hline & $C V(\%)=24,14$ & & & & \\
\hline & Microrganismo & 2 & 71,49 & $\begin{array}{r}37,58 \\
947\end{array}$ & $4,9 \mathrm{E}-12$ \\
\hline & Concentração de BTH & 4 & 7,10 & 3,73 & 0,0080 \\
\hline \multirow[t]{6}{*}{ SA } & Microrganismo $\times \mathrm{BTH}$ & 8 & 1,55 & 0,81 & 0,5935 \\
\hline & Resíduo & 75 & 1,90 & & \\
\hline & Média $=4,27$ & & & & \\
\hline & $C V(\%)=32,28$ & & & & \\
\hline & Microrganismo & 2 & 366,36 & 20,51 & $7,8 \mathrm{E}-08$ \\
\hline & Concentração de BTH & 4 & 120,47 & 6,75 & 0,0001 \\
\hline \multirow[t]{6}{*}{ FR } & Microrganismo $\times \mathrm{BTH}$ & 8 & 15,15 & 0,85 & 0,56 \\
\hline & Resíduo & 75 & 17,86 & 0,85 & \\
\hline & Média $=15,07$ & & & & \\
\hline & $C V(\%)=28,04$ & & & & \\
\hline & Microrganismo & 2 & 4,40 & 21,77 & $3,5 \mathrm{E}-08$ \\
\hline & Concentração de BTH & 4 & 0,78 & 3,86 & 0,0067 \\
\hline \multirow[t]{4}{*}{ SR } & Microrganismo $\times$ BTH & 8 & 0,14 & 0,70 & 0,6920 \\
\hline & Resíduo & 75 & 0,20 & 0,70 & \\
\hline & Média $=1,20$ & & & & \\
\hline & $C V(\%)=37,43$ & & & & \\
\hline
\end{tabular}




\section{Tabela V}

Efeito de dose única de BTH e $\boldsymbol{H}$ glycines no desenvolvimento vegetativo da soja: Análises de variância da regressão e coeficientes de determinação $\left(R^{2}\right)$ das variáveis peso de matéria fresca da parte aérea (FA), peso de matéria seca da parte aérea (SA) e peso de matéria seca da raiz (SR).

\begin{tabular}{|c|c|c|c|c|c|}
\hline Variável & Causas de Variação & $\overline{G L}$ & QM & $F$ & $p$-valor \\
\hline & Regressão & 3 & 24,05 & 5,77 & 0,0017 \\
\hline \multirow[t]{3}{*}{ FA } & Resíduo & 55 & 4,17 & & \\
\hline & $\mathrm{R}^{2}=23,94$ & & & & \\
\hline & Regressão & 3 & 2,20 & 10,59 & $1,29 \mathrm{E}-05$ \\
\hline \multirow[t]{3}{*}{ SA } & Resíduo & 56 & 0,21 & & \\
\hline & $\mathrm{R}^{2}=36,19$ & & & & \\
\hline & Regressão & 3 & 1,11 & 23,91 & $6,39 \mathrm{E}-10$ \\
\hline \multirow[t]{2}{*}{ SR } & Resíduo & 53 & 0,05 & & \\
\hline & $\mathrm{R}^{2}=57,51$ & & & & \\
\hline
\end{tabular}


Tabela VI

Efeito de aplicações de BTH a cada 7 dias e de $\boldsymbol{H}$ glycines e $M$. javanica no desenvolvimento vegetativo da soja: Análises de variância da regressão e coeficientes de determinação $\left(R^{2}\right)$ das variáveis peso de matéria fresca da parte aérea (FA), peso de matéria seca da parte aérea (SA) e peso de matéria seca da raiz (SR).

\begin{tabular}{|c|c|c|c|c|c|}
\hline Variável & Causas de Variação & $\mathbf{G L}$ & QM & $\bar{F}$ & $p$-valor \\
\hline & Regressão & 5 & 27,44 & 13,85 & $1,55 \mathrm{E}-10$ \\
\hline \multirow[t]{3}{*}{ FA } & Resíduo & 112 & 1,98 & & \\
\hline & $\mathrm{R}^{2}=38,22$ & & & & \\
\hline & Regressão & 5 & 2,28 & 20,12 & $2,84 \mathrm{E}-14$ \\
\hline \multirow[t]{3}{*}{ SA } & Resíduo & 112 & 0,11 & & \\
\hline & $\mathrm{R}^{2}=47,31$ & & & & \\
\hline & Regressão & 5 & 0,71 & 24,96 & $7,86 \mathrm{E}-17$ \\
\hline \multirow[t]{2}{*}{ SR } & Resíduo & 112 & 0,029 & & \\
\hline & $\mathrm{R}^{2}=52,71$ & & & & \\
\hline
\end{tabular}




\section{Tabela VII}

Influência do BTH na colonização da soja por B. japonicum e G. intraradices: Análises de variância, médias gerais e coeficientes de variação (CV) das razões entre número de nódulos e peso seco de raiz (Nnod/SR), peso de matéria seca de nódulos e peso da matéria seca da raiz (Pnod/SR) e porcentegem de raízes colonizada por fungo micorrízico arbuscular e peso da matéria seca da raiz(\%FMA/SR).

\begin{tabular}{rlrccc}
\hline Variável & Causas de Variação & GL & QM & $F$ & p-valor \\
\hline \multirow{3}{*}{ Nnod/SR } & Tratamento & 4 & 4414,80 & 2,59 & 0,0610 \\
& Resíduo & 25 & 1703,32 & & \\
& Média= $=71,94$ & & & & \\
& CV(\%)=57,37 & & & & \\
\hline \multirow{5}{*}{ Pnod/SR } & Tratamento & 4 & 3631,75 & 2,80 & 0,0475 \\
& Resíduo & 25 & 1295,94 & & \\
& Média=55,08 & & & & \\
& CV(\%)=65,35 & & & & \\
\hline \multirow{5}{*}{ \% FMA/SR } & Tratamento & 4 & 451,67 & 0,97 & 0,44 \\
& Resíduo & 25 & 465,80 & & \\
& Média=37,43 & & & & \\
& $C V(\%)=57,66$ & & & & \\
\hline
\end{tabular}




\section{Tabela VIII}

Influência de uma única aplicação do BTH na colonização de soja por $H$. glycines: Análises de variância da regressão da razão entre o número de fêmeas e peso seco da raiz e coeficiente de determinação $\left(R^{2}\right)$.

\begin{tabular}{lrrrr}
\hline \multicolumn{1}{c}{ Causas de Variação } & GL & QM & $\boldsymbol{F}$ & \multicolumn{1}{c}{$\boldsymbol{p}$-valor } \\
\hline Regressão & 1 & 3557,24 & 5,18 & 0,0320 \\
Resíduo & 24 & 686,18 & & \\
\cline { 1 - 1 }$R^{2}=17,76$ & & & & \\
\hline
\end{tabular}

\section{Tabela IX}

Influência de aplicações do BTH a cada 7 dias na colonização de soja por H. glycines e M. javanica: Análises de variância da regressão das razões entre o número de fêmeas de $H$. glycines e peso seco da raiz (Nf/SR) e número de galhas causadas por $M$. javanica e peso seco de raiz (Ng/SR) e coeficientes de determinação $\left(R^{2}\right)$.

\begin{tabular}{llrrrr}
\hline Variável & Causas de Variação & GL & QM & $\boldsymbol{F}$ & \multicolumn{1}{c}{$\boldsymbol{p}$-valor } \\
\hline \multirow{3}{*}{ Nf/SR } & Regressão & 1 & 0,30 & 0,00 & 0,97 \\
& Resíduo & 37 & 153,18 & & \\
& $\mathrm{R}^{2}=0,00$ & & & & \\
\hline \multirow{3}{*}{ Ng/SR } & Regressão & 1 & 98720,45 & 6,74 & 0,0133 \\
& Resíduo & 38 & 14652,57 & & \\
& $\mathrm{R}^{2}=15,06$ & & & & \\
\hline
\end{tabular}


Tabela X

Influência do BTH sobre larvas de $\boldsymbol{H}$. glycines e $\boldsymbol{M}$. javanica in vitro: Análises de variância da regressão dos números de larvas de $H$. glycines e $M$. javanica após incubação com BTH e número de galhas em plantas de tomate causadas por larvas pré incubadas com BTH, e coeficientes de determinação $\left(R^{2}\right)$.

\begin{tabular}{|c|c|c|c|c|c|}
\hline Variável & Causas de Variação & $\overline{G L}$ & QM & $\bar{F}$ & $p$-valor \\
\hline \multirow{3}{*}{$\begin{array}{c}\text { Número de larvas } \\
\text { móveis de } \\
\text { H. glycines }\end{array}$} & Regressão & 1 & 0,00 & \multirow[t]{3}{*}{0,06} & \multirow[t]{3}{*}{0,8044} \\
\hline & Resíduo & 18 & 0,00 & & \\
\hline & $\mathrm{R}^{2}=0,00$ & & & & \\
\hline \multirow{3}{*}{$\begin{array}{c}\text { Número de larvas } \\
\text { móveis de } \\
M \text { javanica }\end{array}$} & Regressão & 1 & 0,00 & \multirow[t]{3}{*}{1,45} & \multirow[t]{3}{*}{0,2486} \\
\hline & Resíduo & 13 & 0,00 & & \\
\hline & $R^{2}=0,03$ & & & & \\
\hline \multirow{3}{*}{$\begin{array}{l}\text { Número de galhas } \\
\text { em plantas de } \\
\text { tomate }\end{array}$} & Regressão & 1 & 54,23 & \multirow[t]{3}{*}{0,25} & \multirow{3}{*}{0,6231} \\
\hline & Resíduo & 13 & 214,05 & & \\
\hline & 0,02 & & & & \\
\hline
\end{tabular}




\section{REFERÊNCIAS BIBLIOGRÁFICAS}

ACEDO, J. R.; DROPKIN, V. H. Technique for obtaining eggs and juveniles of Heterodera glycines. Journal of Nematology, v. 14, p. 418-20, 1082.

ALFENAS, A. ,ed. Eletroforese de isoenzimas e proteínas afins; fundamentos e aplicações em plantas e microrganismos. Viçosa: Universidade Federal de Viçosa, 1998. 574pp.

ALFENAS, A. C.; PETERS, I.; BRUNE, W.; PASSADOR, G. C. Eletroforese de proteínas e isoenzimas de fungos e essências florestais. Viçosa: Universidade Federal de Viçosa, 1991. 242p.

ALMEIDA, A. M. R.; FERREIRA, L. P.; YORINORI, J. T.; SILVA, J. F. V.; HENNING, A. A. Doenças da soja. In: BERGAMIN FILHO, A.; KIMATI, H.; AMORIN, L. (ed.) Manual de Fitopatologia. Vol. 2. São Paulo: Editora Agronômica Ceres, 1995. cap 61, p. 642-64.

AZCÓN-AGUILAR, C.; BAREA, J. M. Arbuscular mycorrhizas and biologica! control of soil-borne plant pathogens - na overview of the mechanisms involved. Mycorrhiza, v. 6, p. 457-64, 1996. 
BAKER, C. J.; ORLANDI, E. W. Active oxygen in plant pathogenesis. Annual Review of Phytopathology, v. 33, p. 299-321, 1995.

BEAUCHAMP,C.; FRIDOVICH, I. Superoxide dismutase: improved assays and assay applicable to acrylamide gels. Analytical Biochemistry, v. 44, p.276-87, 1971.

BÉCARD, G.; TAYLOR, L. P.; DOUDS, D. D. PFEFFER, P. E.; DONER, L. W. Flavonoids are not necessary plant signal compounds in arbuscular mycorrhizal simbiosis. Molecular Plant Pathogen Interactions, v. 8, p. 252-8, 1995.

BELLEI, M. M.; CARVALHO, E. M. S. Ectomicorrizas. In: CARDOSO, E. J. B. N.; TSAI, S. M.; NEVES, M. C. P. Microbiologia do Solo. Sociedade Brasileira de Ciência do Solo, Campinas, 1992. Cap.21, p.297-318.

BONFARTE-FASOLO, P. Anatomy and morphology of VA mycorrhizae. In: POWELL, C. L.; BAGYARAJ, D. J., ed. VA Mycorrhiza. CRC Press, Boca Raton, 1984. Cap.2, p.5-33.

BONFANTE-FASOLO, P.; VIAN, B.; PEROTTO, S.; FACCIO, A.; KNOX, J.P. Cellulose and pectin localization in roots of mycorrhyzal Allium porrum: labeling continuity between host cell wall and interfacial material. Planta, v. 180, p. $537-47,1990$. 
BONFANTE, P.; PEROTO, S. Strategies of arbuscular mycorrhizal fungi when infecting host plants. New Phytologist, v. 130, p. 3-21, 1995.

BRADFORD, M. M. A rapid and sensitive method for the quantification of microgram quantities of protein utilizing the principle of protein-dye binding. Analytical Biochemistry, v.72, p.248-54, 1976.

CARDOSO, E. J. B. N.; FREITAS, S. S. A rizosfera. In: CARDOSO, E. J. B. N.; TSAI, S. M.; NEVES, M. C. P. Microbiologia do Solo. Campinas: Sociedade Brasileira de Ciência do Solo, 1992. Cap. 4, p. 41-58.

COHN, E.; KOLTAI, H.; SHARON, E.; SPIEGEL, Y. Root-nematode interactions: recognition and pathogenicity. In: WAISEL, Y.; ESHEL, A; KAFKAFI, U (ed.). Plant roots: the hidden half. Marcel Dekker, New York, 1996a. Cap. 35, p. 789-806.

COLLOZZI-FILHO, A.; BALOTA, E. L. Micorrizas abusculares. In: HUNGRIA, M.; ARAUJO, R. S. Manual de Métodos Empregados em Estudos em Microbiologia Agrícola. Brasilia: EMBRAPA, 1994. cap.20, p. 383-412.

DANGL, J. L.; DIETRICH, R. A.; RICHBERG, M. H. Death has no mercy: cell death programs in plant microbe interactions. The Plant Celi, v. 8, p. 17931807, 1996. 
DANN, E.; DIERS, B.; BYRUM, J.; HAMMERSCHMIDT, R. Effect of treating soybean with 2,6-dichloroisonicotinic acid (INA) and benzothiadiazole (BTH) on seed yields and the level of disease caused by Sclerotinia sclerotium in field and greenhouse studies. European Journal of Plant Pathology. V. 104, p. 271-8, 1998.

DAVID, R.; ITZHAKI, H.; GINZBERG, I.; GAFNI, Y.; GALILI, G.; KAPULNIK, Y. Suppression of tobacco basic chitinase gene expression in response to colonization by arbuscular mycorrhizal fungus Glomus intraradices. Molecular Plant Microbe Interactions, v. 11, p.489-97, 1998.

DAVIS, B. J. Disc electrophoresis II. Method and applications to human serum proteins. Ann. N. Y. Acad. Sci., v.121, p.407-27, 1964.

DAVIS, E. L.; MEYERS, D. M.; DULLUM, C. J.; FEITELSON, J. S. Nematicidal activity of fatty acid esters on soybean cyst and root-knot nematodes. Journal of Nematology, v. 29, p. 677-84, 1997.

DERBYSHIRE, E.; CARVALHO, M. T. V.; BONATO, E. R. Comparison of natural variants of the soybean cultivar Paraná by isoenzyme analysis. Revista Brasileira de Genética, v. 13, p. 83-7, 1990.

DOKE,N. Involvement of superoxide anion generation in the hypersensitive response of potato tuber tissues to infection with na incompatibile race of 
Phytophthora infestans and to the hyphal wall components. Physiological Plant Pathology, v. 23, p. 345-57, 1983.

DONG, K.; BARKER, K. R.; OPPERMAN, C. H. Genetics of soybeanHeterodera glycines interactions. Journal of Nematology , v. 29, p. 50922, 1997.

DUC, G.; TROUVELOT, A.; GIANINNAZZI-PEARSON, V.; GIANINNAZZI. S. First reports of non mycorryzal plant mutants ( $\mathrm{Myc}^{-}$) obtained in pea (Pisum sativum L.) and Fababean (Vicea faba L.). Plant Science, v. 60, p. 215-22, 1989.

DUMAS-GAUDOT, E.; SLEZACK, S.;DASSI, B.; POZO, M. J.; GIANINAZZIPEARSON, V.; GIANINAZZI, S. Plant hydrolytic enzymes (chitinases and $\beta-1,3$-glucanases) in root reactions to pathogenic and symbiotic microorganisms. Plant and Soil, v. 185, p. 211-21, 1996.

DUNCAN, L. W. Current options for nematode management. Annual Review of Phytopatology, v. 29, p. 469-90, 1991.

EMPRESA BRASILEIRA DE PESQUISA AGROPECUÁRIA. Recomendações técnicas para a cultura da soja na região central do Brasil - 1994/95. Londrina: Centro Nacional de Pesquisa da Soja, 1994. 
FISHER, R.; HAIN, R. Plant disease resistance resulting from the expression of foreign phytoalexins. Current Opinion in Biotechnology, v. 5, p. 125-30, 1994.

FODOR, J.; GULLNER, G.; ÁDAM, A. L.; BARNA, B.; KÖMIVES, T.; KIRÁLY, Z. Local and systemic responses of antioxidants to tobacco mosaic virus infection and to salicylic acid in tobacco. Plant Physiology, v. 114, p. 1443-51, 1997.

FREIRE, J. R. J. Fixação do nitrogênio pela simbiose rizóbio / leguminosas. In: CARDOSO, E .J. B. N.; TSAI, S. M.; NEVES, M. C. P. Microbiologia do Solo. Sociedade Brasileira de Ciência do Solo, Campinas, 1992. cap.20, p.281-296.

FRIEDRICH, L.; LAWTON, K.; RUESS, W.; MASNER, P.; SPECKER, N.; RELLA, M. G.; MEIER, B.; DINCHER, S.; STAUB, T.; UKNES, S.; MÉTRAUX, J.; KESSMANN, H.; RYALS, J. A benzothiadiazole derivate induces systemic acquired resistance in tobacco. The Plant Journal, v. 10, p. 61-70, 1996.

GHEYSEN, G.; VAN DER EYKEN, W.; BARTHELS, N.; KARIMI, M.; VAN MONTAGU, M. The exploitation of nematode-responsive plant genes in 
novel nematode control methods. Pesticide Science, v. 47, p.95-101, 1996.

GIANINNAZZI-PEARSON, V. Plant cell responses to arbuscular mycorrhizal fungi: getting the roots of symbiosis. The Plant Cell, v. 8, p. 1871-83, 1996.

GIANINNAZZI-PEARSON, V. ; DUMAS-GAUDOT, E.; GOLLOTTE, A.; TAHIRIALAUI, A.; GIANINAZZI, S. Cellular and molecular defense-related root response to invasion by arbuscular mycorrhizal fungi. New Phytologist, v.133, n.1, p.45-57, 1996.

GOLDBERG, R.; LE, T.; CATESSON, A. M. Localization and properties of cell wall enzyme activities related to the final stages of lignin biosynthesis. Journal of Experimental Botany, v. 36, p.503-10, 1985.

GOLLOTTE, A.; GIANINAZZI-PEARSON, V.; GIANINAZZI, S. Immunodetection of infection thread glycoprotein and arabinogalactan protein in wild type Pisum sativum (L.) or an isogenic mycorryza-resistant mutant interacting with Glomus mosseae. Symbiosis, v. 18, p. 69-85, 1995.

GOLLOTTE, A.; GIANINAZZI-PEARSON, V.; GIOVANNETTI, M.; SBRANA, C.; AVIO, L.; GIANINNAZZI, S. Cellular localization and cytochemical probing resistance reactions to arbuscular mycorrhyzal fungi in a 'locus a' myc' mutant of Pisum sativum L. Planta, v. 191, p. 112-22, 1993. 
GÖRLACH, J.; VOLRATH, S.; KNAUF-BEITER, G.; HENGY, G.; BECKHOVE, U.; KOGEL, K.; OOSTENDORP, M.; STAUB, T.; WARD, E.; KESSMANN, H.; RYALS, J. Benzothiadiazole, a novel class of inducers of systemic acquired resistance, activates gene expression and disease resistance in wheat. The Plant Cell, v. 8, p. 629-43, 1996.

GUZZO, S. D. Elicitação da fitoalexina gliceolina em cotilédones de soja (Glycine max (L.) Merril) por polissacarídeos extracelulares de uredinosporos de Hemileia vastatrix Berk. et $\mathrm{Br}$. Piracicaba, 1989, p. Dissertação (M.S.). Escola Superior de Agricultura "Luiz de Queiroz", Universidade de São Paulo.

HEBERS, K.; MEUWLY, P.; FROMMER, W. B.; METRAUX, J. P.; SONNEWALD, U. Systemic acquired resistance mediated by the ectopic expression of invertase: possible hexose sensing in the secretory pathway. Plant Cell, v. 8, p. 793-803, 1996.

IBRAHIM, I. K. A.; LEWIS, S. A. Interrelationships of Meloidogyne arenaria and M. incognita on tolerant soybean. Journal of Nematology, v. 18, p.106$111,1986$.

KAPLAN, D. T.; KEEN, N. T.;; THOMASON, I. J.; Association of glyceollin with the incompatible response of soybean roots to Meloidogyne incognita. Physiological Plant Patology, v.16, p. 309-18, 1980. 
KAPULNIK, Y. Nonsymbiotic nitrogen-fixing soil microorganisms. In: WAISEL, Y.; ESHEL, A; KAFKAFI, $U$ (ed.). Plant roots: the hidden half. Marcel Dekker, New York, 1996a. Cap. 31, p. 703-12.

KAPULNIK, Y. Plant growth promotion by rhizosphere bacteria. In: WAISEL, Y.; ESHEL, A; KAFKAFI, $U$ (ed.). Plant roots: the hidden half. Marcel Dekker, New York, 1996b. Cap. 32, p. 713-30.

KESSMANN, H.; STAUB, T.; HOFMANN, C.; MAETZKE, T.; HERZOG, J. Induction of systemic acquired disease resistance in plants by chemicals. Annual Review of Phytopatology, v.32, p. 439-59, 1994.

KNOGGE, W. Fungal Infection of plants. The Plant Cell, v. 8, p. 1711-22. 1996.

LAMB, C.; DIXON, R. A. The oxidative burst in plant disease resistance. Annual Review of Plant Physiology and Plant Molecular Biology, v. 48, p. $251-75,1997$.

LAMB, C. J.; RYALS, J. A.; WARD, E R.; DIXON, R. A. Emerging strategies for enhancing crop resistance to microbial pathogens. Biol Technology, v.10, p.1436-45, 1992. 
LAWTON, K. A.; FRIEDRICH, L.; HUNT, M.; WEYMANN, K.; DELANEY, T.; KESSMANN, H.; STAUB, T.; RYALS, J. Benzothiadiazole induces disease resistance in Arabidopsis by activation of the systemic acquired resistance signal transdution pathway. The Plant Journal, v. 10, p. 71-82, 1996.

LAWTON, K. A.; WEYMANN, K.; FRIEDRICH, L.; VERNOOIIJ, B.; UKNESS, S.;RYALS, J. Systemic acquired resistance in Arabidopsis requires salicylic acid but not ethylene. Molecular Plant Microbe Interactions, v.8, p. 86370, 1995.

LIU, S.; NORRIS, D. M.; HARTWIG, E. E.; XU, M. Inducible phytoalexins in juvenile soybean genotypes predict soybean looper resistance in the fully developed plants. Plant Physiology, v. 100, p. 1479-85, 1992.

LONG, S. R. Rhizobium Symbiosis: Nod factors in perspective. Plant Cell, v. 8, p. $1885-98,1996$.

MACKO, V.; HONOLD, G. R.; STAHMANN Soluble proteins and multiple enzyme forms in early growth of wheat. Phytochemistry, v. 6, p.465-71, 1967.

McCULLY, M. E. Roots in soil: unearthing the complexities of roots and their rhizospheres. Annual Review of Plant Physiology and Plant Molecular Biology, p. 695-718, 1999. 
MEHDY, M. C. Active oxygen species in plant defense against pathogens. Plant Physiology, v. 105, p.467-72, 1994.

NEVES, M. C. P.; RUMJANECK, N. Bioquímica e fisiologia da fixação de nitrogênio. In: CARDOSO, E. J. B. N.; TSAI, S. M.; NEVES, M.C.P. Microbiologia do Solo. Sociedade Brasileira de Ciência do Solo, Campinas, 1992. Cap.19, p.282.

NIEBEL, A.; HEUNGENS, K.; BARTHELS, N.; INZÉ, D.; VAN MONTAGU, M.; GODELIEVE, G. Characterization of a pathogen-induced potato catalase and its systemic expression upon nematode and bacterial infection. Molecular Plant Microbe Interactions, v. 8, p.371-8, 1995.

NOGUEIRA, M. A. Colonização radicular e produção de micélio externo por duas espécies de fungos micorrízicos arbusculares em soja submetida a doses de fósforo. Piracicaba, 1997. 92p. Dissertação (M.S.) - Escola Superior de Agricultura Luiz de Queiroz.

OGALLO, J. L; McCLURE, M. A. Systemic acquired resistance and susceptibility to root-knot nematodes in tomato. Phytopatology, v. 86, p. 498-501, 1996.

OSSWALD, W.; PASCHOLATI, S. F.; STANGARLIN, J. R.; LEME, L. D. C. T.; WULFF, N. A. Acúmulo de fitoalexinas em mesocótilo de sorgo em 
resposta ao tratamento com ativador de defesa vegetal "Bion". Fitopatologia Brasileira, n. 23, p. 266, 1998.

PASCHOLATI, S. F.; LEITE, B. Hospedeiro: mecanismos de resistência. In: BERGAMIN FILHO, A.; KIMATI, H.; AMORIN, L. (ed.) Manual de Fitopatologia. Vol. 1. Princípios e Conceitos. São Paulo: Editora Agronômica Ceres, 1995. cap 22, p. 417-53.

PASCHOLATI, S. F.; STANGARLIN, J. R.; HOTO, F. V.; PICCININ, E.; OSSWALD, W. Efeito in vitro do ativador de defesa vegetal "Bion" no crescimento micelial e na germinação de conídeos de Colletotrichum graminicola. Fitopatologia Brasileira, v. 23, p 266, 1998.

PAWLOWSKI, K.; BISSELING, T. Rhizobial and actinorhizal symbioses: what are shared features. The Plant Cell, v. 8, p. 1899-913, 1996.

PENNINCKX, I. A. M. A.; EGGERMONT, K.; TERRAS, F. R. G.; THOMMA, B. P. H. J.; SAMBLANX, G. W.; BUCHALA, A.; MÉTRAUX, J. P.; MANNERS, J. M.; BROEKAERT, W. F. Pathogen-induced systemic activation of a plant defensin gene in Arabidopsis follows a salicylic acid-independent pathway. The Plant Cell, v. 8, p. 2309-23, 1996. 
PIETERSE, C. M. J.; VAN WESS, S. C. M.: HOFFLAND, E.; VAN PELT, J. A.;VAN LOON, L. C. Systemic resistance in Arabidopsis induced by biocontrol bacteria is independent of salicylic acid accumulation and pathogenesis-related gene expression. The Plant Cell, v. 8, p. 1225-37, 1996.

QIU, J.; HALLMANN, J., KOKALIS-BURELLE, N.; WEAVER, D. B.; RODRÍGUEZ-KÁBANA, R. ; TUZUN, S. Activity and differential indution of chitinase isozymes in soybean cultivars resistant or susceptible to root-knot nematodes. Journal of nematology, v. 29, p. 523-30, 1997.

REINBOTHE, S.; MOLLENHAUER, B.; REINBOTHE, C. JIPs and RIPs: the regulation of plant gene expression by jasmonates in response to environmental cues and pathogens. The Plant Cell, v.6, p.1197-209, 1994.

REISFELD, R. A.; LEWIS, U. J.; WILLIAMS, D. E. Disc electrophoresis of basic proteins and peptides on polyacrylamide gels. Nature, v. 195, p. $281-3$, 1962.

RIDGE, I.; OSBORNE, D. J. Hydroxyproline and peroxidases in cell walls of Pisum sativum: regulation by ethylene. Journal of Experimental Botany, v. 21, p.843-56, 1970. 
ROSS, A. F. Localized acquired resistance to plant virus infection in hypersensitive hosts. Virology, v. 14, p.329-39, 1961 a.

ROSS, A. F. Systemic acquired resistance induced by localized virus infections in plants. Virology, v. 14, p.340-58, 1961 b.

RUDOLPH, K.; STAHMANN, M. A. Interactions of peroxidases and catalases between Phaseolus vulgaris and Pseudomonas phaseolicola (halo blight of bean). Nature, v.204, p. 474-5, 1964.

RYALS, J. A; NEUENSHWANDER, U. H.; WILLITS, M. G; MOLINA, A; STEINER, H.; HUNT, M. Systemic acquired resistance. The Plant Cell, v. 8, p. 1809-19, 1996.

SARRUGE, J. R. Soluções nutritivas. Summa Phytopatologica, v. 1, p. 2313, 1975.

SCHURTER, R.; KUNZ, W.; NYFELER, R. Process and composition for immunizing plants against diseases. U.S. Patent No 4,931,581. 5 jun. 1990.I GÖRLACH, J.; VOLRATH, S.; KNAUF-BEITER, G.; HENGY, G.; BECKHOVE, U.; KOGEL, K.; OOSTENDORP, M.; STAUB, T.; WARD, E.; KESSMANN, H.; RYALS, J. Benzothiadiazole, a novel class of inducers of 
systemic acquired resistance, activates gene expression and disease resistance in wheat. The Plant Cell, v. 8, p. 629-43, 1996.

SCOTT-CRAIG, J. S.; KERBY, K. B.; STEIN, B. D.; SOMERVILLE, S. C. Expression of an extracellular peroxidase that is induced in barley (Hordeum vulgare) by the powdery mildew pathogen (Erysiphe graminis $f$. sp. hordei). Physiological and Molecular Plant Pathology, v. 47, p.40718, 1995.

SHARMA, R. D. Reaction of soybean genotypes to Meloidogyne javanica. Nematologia Brasileira, v. 17, p. 9-10, 1933.

SIEGRIST, L.; GLENEWINKEL, D.; KOLLE, C.; SCHMIDTKE, M. Chemically induced resistance in green bean against bacterial and fungal pathogens. Journal of Plant disease and protection, v. 104, p.599-610, 1997.

SIJMONS, P. C.; ATKISON, H. J.; WYSS, U. Parasitic strategies of root nematodes and associated host cell response. Annual Review of Phytopatology, v. 32, p. 235-59, 1994.

SILVEIRA, A. P. D. Micorrizas. In: CARDOSO, E. J. B. N.; TSAI, S. M.; NEVES, M.C.P. Microbiologia do Solo. Sociedade Brasileira de Ciência do Solo, Campinas, 1992. Cap.19, p.282. 
SIMON, L.; BOUSQUET, J.; LÉVESQUE, R. C.; LALONDE, M. Origin and diversification of endomycorrhizal fungi and coincidence with vascular land plants. Nature, v.363, p.67-9, 1993.

SPAINK, $H$. The molecular basis of infection and nodulation by rhizobia: the ins and outs of sympathogenesis. Annual Review of Phytopatology. V. 33, p. $345-68,1995$.

STAEHELIN, C.; MÜLLER, J.; MELLOR, R. B.; WIEMKEN, A.; BOLLER, T. Chitinase and peroxidase in effective (fix $x^{+}$) and ineffective (fix) soybean nodules. Planta, v. 187, p. 295-300, 1992.

STROBEL, N. E.; I, C.; GOPALAN, S.; KUC, J. A.; HE, S. Y. Induction of systemic acquired resistance in cucumber by Pseudomonas syringae pv. syringae 61 HrpZPss protein. Plant Journal, v. 9, p. 431-9, 1996.

TODD, T.C. Soybean planting date and maturity effects on Heterodera glycines and Macrophomina phaseolina in southeastern Kansas. Journal of Nematology, v.25:731-737, 1993.

TRUDEL, J.; ASSELIN, A. Detection of chitinase activity after polyacrylamide gel electrophoresis. Analytical biochemistry, v.175, p. 362-6, 1989. 
TRUDGILL, D. L. Resistance to and tolerance of plant parasitic nematodes in plants. Annual Review of Phytopatology, v. 29, p. 167-92, 1991.

UKNES,S; VERNOOIJ, B.; MORRIS, S.; CHANDLER, D.; STEINER, H. Y.; SPECKER, N.; HUNT, M.; NEUENSSCHWANDER, U.; LAWTON, K.; STARRETT, M.; FRIEDRICH, L.; WEYMANN, K.; NEGROTTO, D.; GÖRLACH, J.; LANAHAN, M.; SALMERON, J.; WARD, E.; KESSMANN, H.; RYALS, J. Reduction of risk for growers: methods for the development of disease-resistant crops. New Physiologist, v.133, p. 3-10, 1996.

VAN LOON, L. C. Tobacco polyphenoloxidases: a specific staining method indicating non identity with peroxidases. Phytochemistry, v.10, p. 503-7, 1971.

VEECH, J. A.; McCLURE, M. A. Terpenoid aldehydes in cotton roots susceptible and resistant to the root-knot nematode Meloidogyne incognita. Journal of Nematology, v. 9, p. 2259, 1977.

WALKER, C. AM or VAM: What's in a Word? In: VARMA, A.; HOCK, B. Mycorrhiza. Springee-Verlag, Berlin, 1995. p.25-6.

WARD, E. R.; UKNES, S. J.; WILLIAMS, S. C.; DINCHER, S. S.; WIEDERHOLD, D. L.; ALEXANDER, D.C.; AHL-GOY, P.; MÉTRAUX, J.; 
RYALS, L. J. Coordinate activity in response to agents that induce systemic acquired resistance. The Plant Cell, v. 3, p. 1085-94, 1991.

WILLIAMSON, V. M. Root-knot nematode resistance genes in tomato and their potential for future use. Annual Review of Phytopatology, v. 36, p. 27793, 1998.

WILLIAMSON, V. M.; HUSSEY, R. S. Nematode pathogenesis and resistance in plants. The Plant Cell, v. 8, p. 1735-45, 1996.

WRATHER, J. A.; ARYSAD, D. M.; GAI, J.; PLOPER, L. D.; PLOTA-PUGLIA, A.; RAM, H. H.; YORINORI, J. T. Soybean disease loss estimates for the top 10 soybean producing countries in 1994 . Plant disease, v. 81, p. $107-$ 10, 1997.

WRATHER, J. A; ELROD, J. M. Apparent systemic effect of Colletotrichum truncatum and $C$. lagenarium on the interaction between soybean and $C$. truncatum. Phytopatology, v. 80, p. 472-4, 1980.

YI, S. Y.; HWANG, B. K. Differential induction and accumulation of $\beta-1,3-$ glucanase and chitinase isoforms in soybean hypocotyls and leaves after compatible and incompatible infection with Phytophthora megasperma f. sp. 
glycinea. Physiological and Molecular Plant Pathology, v.48, p.179-92, 1996.

ZACHEO, G.; ORLANDO, C.; BLEVE-ZACHEO, T. Characterization of anionic peroxidases in tomato isolines infected by Meloidogyne incognita. Journal of Nematology, v. 25, p. 24956, 1993.

ZHANG, W.; DICK, W. A.; HOITINK, H. A. Compost-induced systemic acquired resistance in cucumber to Pythium root rot and anthracnose. Phytopathology, v. 86, p. 1066-70, 1996. 